\title{
A Study of Political Stability in Malaysia: A Study about National Civilian Perception
}

\author{
Looi Theam Choy \\ (University Of Tun Abdul Razak, Malaysia)
}

\begin{abstract}
This research is focused on political stability in Malaysia through civilian's perception. To identify a structural stabilized political system, it depended on several important factors. Those particular factors contain manpower development, economic development and growth, governance, political culture, technology development, security environment and social development. In addition, our political system also influenced and balanced by certain moderate factors such as control of inflation and leader, invention and innovation and civilian support. The relationship between the factor of economic development and growth and stabilized political system is controlled and balanced by an external factor called control of inflation and leader consisting politician \& economist. Moreover, national governance and our stabilized political system are balanced and controlled by an important factor called control of corruption and leaders consisting national politicians. Technology development is one of the mentioned factors too that influences national political system but it controls and balances by the factor of invention and innovation. In addition, without social development, our political system would not be stable due to least civilian's support force. The manpower development factor and economy development and growth factor are significantly related to influence our political system. Meanwhile, economy development and growth factor and governance factor also significant related to stabilize political system in Malaysia. Our stabilized political system also depending on both governance factor and political culture factor significantly. To develop Malaysia, social development factor and national governance factor are significantly related to influence national politic system.
\end{abstract}

Key words: Control of Inflation, Economy Development and Growth, Governance, Manpower development, Political Stability.

\section{Introduction}

East Asia has only partially shared in the Third Wave of democratization that spread around the globe in the 1990s. Indeed, the severe economic problems of the late 1990s raised concerns about the increasing trends of public protest and dissatisfaction in some of the consolidated democracies of East Asia, such as Japan and Korea. In other nations, democracy regressed or made only little progress during this decade. The newest findings from the 2000-2002 World Values Survey enable us to assess how people across East Asia now think about democracy and the value of a democratic regime. For the consolidated democracies of Japan, Korea and Taiwan, support for democracy occurs along with spreading public criticism of politicians, parties and political institutions in recent years. Indeed, the World Values Survey also finds decreasing public trust of the political process and declining confidence in political institutions. In contrast, many other nations in East Asia function with the presumption that citizens accept the current non-democratic regime, and the political culture of the nation is not ready for democracy. The citizens of these nations do the fit this model-they express democratic ideals and aspirations. Even if they are inevitably unsure about how democracy actually functions, they see it as preferable to the non-democratic alternatives with which they are familiar (Dalton \& Doh, 2003).

Both Western and Chinese commentators, when listing the controversial anniversaries in 1999, ignore the Democracy Wall movement. True, the movement began in late 1978, but it reached its climax and ended in late 1979. While China's leaders refer to June 4th as "an unfortunate incident," none of them refer to the Democracy Wall movement, nor, for that matter, did the participants in the Tiananmen Square demonstrations of spring 1989. Though a number of the Democracy Wall activists, now in exile in the United States, commemorated the event in the summer and fall 1998 issues of China Rights Forum, its anniversary has come and gone without provoking much comment either in China or in the Western media and academic community. China's leaders may choose to ignore the Democracy Wall movement for political reasons, but that does not explain why others should follow their lead. Perhaps the violent events of June 4, 1989 have superceded and focused attention on the later movement, but from the perspective of the end of the 20th century, the Democracy Wall movement, much more than the spring 1989 Tiananmen demonstrations, was a transformative political event in the People's Republic. It precipitated unprecedented political debates, fresh political issues, unofficial magazines, and independent political organizations. As Wang Juntao, one of the participants in both events, has pointed out, the political activists who came to the fore in the Democracy Wall movement played a key role in 
China's "struggle for democratic change"1 in the post-Mao era. This movement not only began the public critique of the Cultural Revolution and Mao's policies and demanded a reversal of the unjust verdicts of the Mao period (1949-76), it also for the first time in the People's Republic called publicly for political reform and human rights. Unlike the participants in the spring 1989 demonstrations, who begged the party to reform, the participants in Democracy Wall movement attempted to achieve their own political rights (Goldman, 2001).

In a nation in which democracy has a long continuous history, there are typically many political leaders who have established reputations for using political power within constitutional limits to serve the voting public. But in a nation that is emerging from one or more generations of authoritarian rule, such good democratic reputations are typically lacking. To win high office in the old authoritarian regime, ambitious officials needed to cultivate reputations for using power to serve their superiors and to reward their supporters in the political hierarchy. Given politicians with such authoritarian reputations for serving others within the political elite, voters in a new democracy would naturally expect that the winner of the first election for control of the national government will use power only for personal benefit and to benefit the inner circle of active supporters. Thereafter, the voters may also naturally believe that any other politician would behave the same way, if that politician could take the place of the incumbent leader. With such low expectations, voters are unlikely to support democratic challengers to the ruling party, and they might see little reason to protest if the government suppressed its political opposition. From this perspective, the central problem for a new democracy may be to create good democratic reputations where they have not previously existed. Intuitively, a successful solution to this problem becomes more likely when more politicians are given independent opportunities to begin cultivating such reputations. The extent of such opportunities may depend critically on the constitutional division or separation of powers in a new democracy (Myerson, 2006).

In addition, the new democracies in the sub-region Southeast Asia - Indonesia, the Philippines, and Thailand - have been politically unstable and slower to recover economically. They face continued protest by civil societies demanding good governance and rapid development after the end of developmental dictatorships. Viewed in isolation, the recent military coup in Thailand - the 18th in 74 years - seems part of an endless cycle, much like what the ancient Greek's termed "eternal recurrence" in history. Seen from a regional, comparative perspective, however, the Thai experience fits a pattern also characteristic of political developments in the Philippines and, to a lesser extent, Indonesia. In this article, I argue that the new democracies in Southeast Asia are following a similar political trajectory that results from dialectic of good governance and democracy. Initially invoked during anti-dictatorship struggles, the good governance discourse has been directed against democratic institutions in reaction to the rise of money politics and populist challenges. Moreover, ASEAN is the formal political association of Southeast Asia. Political conflict has hindered the founding of a similar organization in East Asia (initially between communists and anti-communists, more recently between China and Taiwan). The "Asia-Pacific Economic Cooperation" (APEC) has not effectively embodied a regional identity. The inclusion of North and some of Latin America as well as Australia makes it too broad, and too Western. More to the regional point was Malaysia's Prime Minister Mahathir's attempt to form the "East Asian Economic Caucus" which would have been centered on Japan, but exclude the Americans (North and South) and the Australians. Only the veto by a Japan that could not say yes in the face of U.S. disapproval kept the idea from gaining ground (Thompson, 2007).

Regarding to the conclusion of Kreutz, since the end of the cold war, the deliberate killings of civilians have been least common in consolidated democratic states without an ongoing armed conflict. Previous research has found that such states almost never fight each other, and there is also a very low risk of intrastate conflict in such a context. It can thus be suggested that the increase of consolidated democracies since the cold war has decreased the risk of conflict as well as one-sided violence in the world. In the same time period, there has also been an observable increase in anocratic states, which are countries that are neither fully democratic nor fully autocratic. These countries have the greatest risk for the outbreak of armed conflict and they have also experienced the most intentional attacks on civilians in the time period. Both governments and other actors have been most common in these states. Democratic governments has been the least likely to attack civilians regardless of whether they were involved in a conflict or not. There is, however, one troubling observation in consolidated democracies (Kreutz, 2006). In addition, the research report defined by Beadle has highlighted certain issues and difficulties in terms of finding 'utility of force to protect'. The report shows that at times when civilian lives are most directly threatened, and when faced with highly dedicated enemies that cannot be coerced, past methods of using force to protect are insufficient. The incapacity to provide the most basic protection is a fundamental flaw when the 'ultimate determinant in war is the man with the gun' and when provision of initial protection is a prerequisite for success in the longer run (Beadle, 2010).

In 1991, Mahathir also presented a new development philosophy, entitled "Malaysia: the way forward", also known as "Vision 2020", which would serve to reinforce the New Development Policy (NDP). Vision 2020 stressed the need for political stability, the promotion of industrialization, and growth in business and technology, in order to bolster economic development, enhance national unity and reduce poverty (Sato, 2005). 
The purpose of this study is defined the reason and requirement of stabilized political system through actual democracy from above stated statements. In facts, Malaysia governance is derived from democratic system but it is fully implemented in our nation and society? Presently, national civilians or citizens are not satisfying the implementation and development of political parties such as Barisan National (BN). Hence, this study focuses on various factors to stabilize our politic by effective stated democratic system. The effective stated democratic system requires the perception from our national civilians before making conclusion due to our nation is obeying democratic system.

\subsection{Background To The Research Problem}

At independence (Merdeka) in 1957, economic conditions in Malaysia (then the Federation of Malaya) appeared favourable. But the country had to face the challenge of a plural society inherted from the colonial past. At the tie, the native Malays, who accounted fro 52 per cent of the population, dominated politics, but were relatively poor, being involved mostly in low-productive agricultural activites. The ethnic Chinese (37 per cent of the population) enjoyed greater economic power and dominated most of the modern-sector ativities, but lacked the ethnic solidarity or political power of the Malays. Economic policy-making in post-independence Malaysia therefore became a continuing struggle to promote development while preserving communal harmony and political stability. During the first decade of independence, the government continued the colonial opendoor policy stance to trade and industrial, while attempting to redress ethnic and regional economic imbalances through rural development schemes and the provision of social and physical infrastructure. Lieke many other developing countries at this time, Malaysia sought industrialisation through import-substitution policies. However, unlike other countries, Malaysia eschewed forced industrialisation through high tariffs and quantitative import restrictions and the establishment of state-owned industrial enterprises (Lim, 1992). Foreign investment was welcomed during this period. But its impact on the economy was limited for two reasons: (1) in the absence of binding import restrictions, there was no compelling reason for foreign producers to establish import-substituting plants in Malaysia; and (2) the internationalisation of production within vertically intergrated global industries had not yet begun. Economic expansion during 1957 until 1969 through respectable failed to make a substantial contribution towards solving special problems of the Malay. On the other hand, with urban unemployment rising and education and language again looming as issues, non-Malays began to question the extent to which their interests were being safeguarded in the new Malaysia. The bloody communal riots of May 1969 were resulted in a clear shift from policy-making based purely on econmic considerations and towards a policy of affirmative action based on ethnicity. This New Economic Policy (NEP) formed the basic of the Second Malaysia Plan (1971-75) (Prema Chandra Athukorala \& Jayant Menon, 1997). The Malay special position is one of the most divisive ethnic issues in Malaysia since comprehensive implementation of New Economic Policy (NEP) (Lee 1990: 486-8). This is ironic when we consider the fact that the very same policy was meant to reduce ethnic tensions through social restructuring and poverty eradication (Chai Ming Hock, 2006). In fact, during 1957-69 periods, the benefits or interests of non-Malay citizens had been influenced by Malay race through economic expansion. The Malay citizens concerned and requested their special status in Malaysia. In addition, ethnic relations have always been the leitmotif of Malaysian politics since the Country's independence in 1957. The government has been a coalition of ethnic-based political parties. The Alliance, which ruled the country from 1957 to 1972, was a coalition of political parties composed of the United Malays National Organization (UMNO), the Malaysian Chinese Association (MCA), and the Malaysian Indian Congress (MIC). After 1972, the Alliance was broadened to include several smaller parties and was renamed the National Front (Barisan Nasional). The dominant political party in the coalition is undoubtedly the UMNO (Ho, 1992).

In 1969, opposition parties were able, not unlike in the recent polls, to reduce the majority of the governing coalition, which won only 74 of 144 seats at the federal level. In West Malaysia, it gained only 48.4 percent of the votes. The polarization during the election campaign led to ethnic riots. A state of emergency was proclaimed (and was in place until 1971), and the ruling coalition integrated a few parties that had belonged to the opposition. Malaysia became more authoritarian, and party-based political opposition was largely marginalized (Ufen A., 2008). The riots on May $13^{\text {th }} 1969$ erupted following the general election, which saw the Chinese-dominated opposition make sizeable gains at the expense of the Malay-dominated ruling coalition. A National Operation Council (NOC) was established under Tun Razak's chairmanship to study the causes of the riots and respond to what was seen as a national emergency. The NOC's first major recommendation was that part of the 1957 constitution be amend to give Parliament the authority to pass laws curtailling protest. The amendment focused on the so-called "sensitive issues" of citizenship, national language, sovereignty of the rulers and the special position of Malays in Malay society. Through the amendment of Article 63 and 72, these issues were effectively removed from public debate even in Parliament. The NOC's concluded that one of the triggers of the ethnic riots was the economic disparity that existed between the Malays and Chinese. Following the 1969 riots the new economic policy was formulated as a broad attempt to alleviate economic inequalities and 
to try to prevent further inter- ethnic conflicts. Its primary objectives were the "eradication of poverty" and "restructuring society and economic balance" (Milne \& Mauzy. 1978. p. 326). A key element of the New Economic Policy (NEP) would be education, in light of the government's efforts to target the ethnic pattern of employment (Sato, 2005). Obviously, inter-ethnic conflict especially Chinese and Malay citizens are derived from ethnic economic inequality. Thus, it may happen again if balanced economy is not handle and manage well in Malaysia. Moreover, national governance also may influence again by inter-ethnic conflict according to the Sato's statements.

Malaysia's system is conceptualized in the political science literature as a "semi-democracy," a "syncretist state," or an example of a "repressive-responsive regime." Recently, the political system has been categorized as an electoral authoritarian regime. Such regimes hold regular elections but systematically violate principles of freedom and fairness: elections are inclusive and pluralistic, but not fully competitive and open. They are different from "closed" authoritarian systems and from electoral democracies "in which the legislative and chief executive offices are filled through regular, competitive, multiparty elections with universal suffrage (Ufen, 2008)."

One of the incidents was happened in Perak state, former Perak Menteri Besar Dtuk Seri Mohammad Nizar Jamaluddin succeeded in his to get leave from a high court to challenge the validity of the appointment of his successor. Justice Abdul Aziz Abd. Rahim ruled that the leve application for a judical review was not frivolous or veatious and that Nizar had convinced the court there was an arguable case. In granting the leve under Order 53 of the Rules of the high court 1980, Justice Abdul Aziz said tht the court did not have to see the metric at the leve application stage. "The applicant has a very low thereshold to meet at the leave stage," he said in his ruling in open court yesterday. Justice Abdul Aziz added that he was bound by an apex court ruling that leave could be granted to Nizar if it found there were issues to be investigated further with submission by both parties. In his suit filed on Feb 13, Nizar, a PAS member, challenging the legitimacy of his successor Datuk Dr. Zambry Abd. Kadir and the new state government. He is seeking a declartion that he is the rightful Perak Menteri Besar and an injunction to bar Dr. Zambry from dischargin his duties as the Menteri Besar. Justice Abdul Aziz said he agreed with Sulaiman that the material tacts wee not questioned while both parties agreed that the Sultan of Perak had absolute discretion over the dissolution of the State Assembly and the appointment of the Menteri Besar. He added that Nizar only questioned the validity of the appointment of Dr. Zambry and that he had asked the Sultan to dissolve the State Assembly to prevent a "dead-lock". However, the ruler did not grant his request (Mageswari, 2009). The above insident was made PAS supporters against BN party in Perak state recently. Due to the above political problems, Karpal Singh was alleged to have uttered seditious words during a media conference relating to Sultan of Perak Sultan Azlan Shah's consent to remove Datuk Seri Mohammad Nizar Jamaludinas the Menteri Besar (Teh, 2009). In addition, as UMMO enters the final lap of its election campaign, candidates vying for party posts have stepped up their campaign amid speculation that more leaders are being investigated by the party disciplinary board. It was pointed out that formar minister Tan Sri Mohd. Isa Samad, who was hauled up in the 2004 party election campaign, was penalised for offences commited the night before polling. To date, a total of 15 people including deputy president candidate Datuk Seri Mohd. Ali Rustam have been punished for money politics charges. Some of them were suspended from their party posts while Mohd Ali has been barred from contesting (Tan, 2009). Obviously, political leader's negative behaviors and attitudes have been influencing political parties internally. Moreover, it also affected the image of political party from Malaysia civilians. Consequently, a driving factor behind Barisan's loss in the polls was the recent takeover of the Perak government which had irked many voters, who threw their support behind Pakatan (Teh \& Chooi, 2009).

Based on the declaration by Chai Ming Hock, consociational politics is the foundation to political stability in Malaysia (Lipjhart 1977: 151). Malaysia is a constitutional monarchy which practices parliamentary democracy. Malaysia was ruled by the Alliance (and BN after 1971) since independence. BN consists of UMNO, Malaysian Chinese Association (MCA), Malaysian Indian Congress (MIC) and other component parties. Even though Malaysia is called a multiracial society par excellence (Vasil 1971: 3), all the main political parties in BN are ethnic-based and represent the interests of each community. As an extension to this racialised political arrangement, "even issues not originating as ethnic ones very quickly become ethnic issues" and the situation evolves into a sort of a zero-sum game when the ethnic division in Malaysia "is simply between the Malays and non-Malays" (Zakaria \& Suzaina 2005: 44-5). Within the coalition power structure, UMNO dominates all the top positions of BN. In politics, UMNO is a senior partner, while MCA and MIC are junior coalition partners (Lipjhart 1977: 151-2). In 2004, over 70 percent of ministries are headed by members of UMNO.1 Sothi Rachagan observed in 1980 that Chinese representation in the ruling Cabinet was already proportionately smaller than Malay representation (Rachagan 1980). Fundamentally, the main issue within coalition is representation of multi-ethnicity within the reality of UMNO domination (Barraclough 1984: 415) (Chai, 2006). Generally, national citizens have been controlling and leading by politic under Malay ethnic. 
In February 2008, Badawi called a snap election for the following month, just under the April deadline for restoring Anwar's right to run for office. According to By Malaysian standards, the March 8 polls were a debacle for Badawi and his incumbent National Front (NF). Not since 1969 had the ruling coalition failed to win a two-thirds majority in parliament. From having lost only one of Malaysia's thirteen state legislatures in the 2004 election, the NF lost five in 2008. I recap these events for two reasons. First, however discouraging the enduring scarcity and compromised quality of democracy in Southeast Asia may be, the region is not immune to political change. Second, furthering democracy in Southeast Asia depends less on underlying preconditions than on political entrepreneurship of the right kind, at the right time, and in the right place (Emmerson, 2008).

\subsection{Problem Statement}

The scene changed dramatically with the occurrence of the racial riots of 1969. The racial riots could be viewed as one of "the ripe moments that produce innovation."The innovation" which emerged from this crisis was an economic policy that would assist the Malay community. One of the causes of the riots, seen from the perspective of the government, was economic in nature - that the Malay poor felt increasingly dissatisfied with government programmes that did not benefit them. The non-Malays were conscious that they had to foster some kind of economic cooperation with the Malays (Ho, 1992).

For the first time since 1969 the BN coalition did not win a two-third majority in the Malaysian Parliament required to pass amendments to the Malaysian constitution. Bn was able to form the next government but without two-third majority (Fischer, 2009). In addition, by the mid-60s, there was increasing dissatisfaction among the Malay population with the government's ability to alleviate poverty in Malay communities (Torii,2001, p. 134). In 1966, Majlis Amanah Rakyat or the Trust Council for Indigeneous People (MARA) was established to improve the social condition of the Bumiputra (Sato, 2005). Based on the Sato's statements, some of the national Malay ethnic also were not satisfied governmental implementation in society.

Malaysia has a bicameral parliament. The first chamber, the Senate, is rather insignificant. The second chamber is the House of Representatives (Dewan Rakyat), the members of which are elected through a plurality vote in single- member constituencies for a maximum term of five years. The governing coalition, the National Front (Barisan Nasional, BN), has won every election since national independence in 1957. As mentioned above, elections in Malaysia are competitive only to a certain extent, which puts the opposition at a great disadvantage. The constitution provides for an independent Election Commission, but in reality this commission is largely controlled by the government. Moreover, the hegemony of the United Malays National Organization (UMNO) has become increasingly fragile. Since the 1980s, the party's dependence on its coalition partners to achieve electoral success has grown. At the same time, UMNO has been transformed more and more into a huge patronage machine, which has heightened factionalism as well as corruption and lessened legitimacy (Ufen, 2008).

According to Emmerson's declaration, Anwar Ibrahim's route to regional influence was more troubled and circuitous than Surin's. In Malaysia in 1998, a year after Anwar had proposed that ASEAN consider "constructive interventions" in Southeast Asia on behalf of improved democratic procedures, civil society, and the rule of law, he was stripped of his position as deputy prime minister, jailed, beaten, and convicted on questionable charges of sodomy and corruption. The first of these convictions was overturned in 2004, and he was released, but not before having served six years in prison. Though free, he was banned from running for political office in Malaysia until April 2008. The man who had upheld noninterference against Anwar's case for "constructive interventions" in 1997, Abdullah Badawi, went on to become Malaysia's prime minister in 2003, while Anwar wrote and lectured around the world on behalf of democracy and actively supported the political opposition at home (Emmerson, 2008).

In the wake of the political crisis incited by the Anwar case of 1998-99, a novel form of Malay vernacular political literature emerged. This type of Reformasi discourse attacked what it saw as the moral decline of politics, secular elites, religions and nation. Moreover, the election on 8 March 2008 saw overwhelming voter support for the federal-level opposition parties in five out of 14 states. BN was reduced to 51 percents and the opposition gained greater representation in Parliament. This landslide victory emphasized demands for democratic media reform in Malaysia among other issues (Fischer, 2009).

A review of literature has defined that UMNO power-base has been seriously eroded by the Opposition Front, the Barisan Alternatif led by PAS. Indeed, PAS was the greatest beneficiary of the 1997-98 economic and political crises. Apart from retaining Kelantan, Pas was able to capture Terengganu and also made significant inroad into several other states such as Kedah, Pahang, Selangor and Perak. The 1999 the general election clearly indicated that UMNO was largely rejected by the Malays; its traditional power-base, and now had to count on the non-Malays in order to remain in power. To what extent UMNO could regain its influence among the Malays, especially the younger generations and the middle class, before the next general election remain to been seen (Ishak, 2002). 
According to the news wrote by Simon and Kevin Kam, Barisan Nasional (BN) may not contest the Penanti state by-election if there is a census among all component parties that it will be a waste of funds, Prime Minister Datuk Seri Najib Raza said. Najib said he would not rule out the possibility of BN not contesting as the latest by-election was "clearly a political ploy" by the opposition (Khoo \& Kam, 2009). Obviously, status of PKR party is too strong occupying Penang state to lead our Prime Minister Datuk Seri Najib B. Razak needs more time to decide election in Penang state.

UMMO vice-president Tan Sri Muhyiddin Yassin said it showed that PKR and Pakatan Rakyat were incable of administering a government. The crisis shows a shaky government and proves they are incapable, they wanted to hide it at firs, but now it has become a crisis, "' he said. Muhiyiddin said it also showed that some of the leaders wee not able to place the people's interests above theors and hoped that the pblic realised that the opposition could not lead effectively. UMMO vice-president Tan Sri Muhammad Taib said Fairus resignation was an internal matter but "it shows that running a government is not easy. Penang UMMO secretary and opposition leader Datuk Azhat Ibrahim claimed that Mohammad Fairus had not performed the duties entrusted to him well and that it was best that he resigned. He alleged that Mohammad Fairus did not bring any development projects to the rural areas. State deputy MCA chairman Eng Hiap Boon said Fairus resignation proved that Pakatan leaders did not have good leadership qualities. "Pakatan Rakyat does not have what it takes lead Penang. I have heard rumours that some of its leaders do not share similar directions with the top leadership", he said (Vinesh \& Tan, 2009). Obviously, negative critics between diferrent political leaders at diferent parties are trend to lead our country under political environment. According to the news, written by The Eng Hock, Khaled feels that UMMO delegtes are no longer voting along state lines but will go with the credentials of candidates. He pointed out that the political landscape was fast changing and UMMO must adapt to remain relevant while overcoming challenges like negative perception and complacency (Teh, 2009).

Ordinary folk like us also know that corruption is a criminal offence and not merely a breach of an individual political party's code of ethics, but going by the statements that have been flying around since the Malaysia Anti-Corruption Commision (MACC) was formed and began performing its duties, this simple truth seems lost on many politicians. Many manage to deny this simple truth by sing such euphemisms such as "money politics", so let me spell it out for our lawmakers: It's corruption! No two-ways about it. A few months ago, when MACC first started hauling up minor political leaders, a branch chairman of a major political party said at a public gatherig that this "crackdown" would only dstroy the party. He said something to the effect of: "Once MACC declares somebody guilty, he can't prove his innocence and will not be able to participate in the party polls. It's unfair. We should leave such matters to the party to handle." Corruption is not just a party matter. It's a criminal offence. Any political leader or party member who does not realise this is in essence encourging criminal acts. More recently, one of the smarter politicians around actually said that there was need for the party's iternal mechanism because not all corruption involved money and therefore did not fall under the MACC purview. Corruption involves any sort of gratification. It doesn't have to be money. Section 3 of the Malaysia Anti-Corruption. Commission Act 2009 defines "gratification" as inluding money, donations, gifts, loans, fees, rewards, valuable security, property or interest in property, office, dignity, employment, contract of employment or services and even any "valuable consideration of any kind" and "any other service or favour of any description." Every time there is a by-election around the corner or some sort of power grab playing out, someone will come out and confess that he was offered a bribe. Perhaps our anti-corruption laws should include clauses that make those who were offered bribes and failed to lodge a report within a certain timeframe, as criminally culpable too (Asohan, 2009). In fact, corruption in political parties is one of the factors to destroy stability of political system in Malaysia. This serious problem always makes Malaysia citizens unsatisfy the current political system. One of the examples had announced from Star's newspaper, Ismail, the barisan Nasional candidate who lost to PAS Datuk Seri Mohammad Nizar Jamaluddin on Tuseday, admited that the campaign had taken a toll on his home life. He accused pakatan Rakyat of smearing his good name during the campaign by curculating compromising photographs, susposedly of im, and alleged that he had written a letter to Prime Minister Datuk Seri Najib Tun Razak to apologise for his corruption practices (Teh \& Chooi, 2009).

In addition, the high court will wait on Monday whether Datuk Seri Mohammad Nizar Jamaluddin or his successor Datuk Seri Dr. Zambry Abdul Kadir is the rightful Perk Menteri Besar. Justice Abdul Aziz Abd Rahim said this was due to the "urgency of the matter", and fixed 2.30pm to deliver his judgement. The Perak state Assembly was thrown into chaos yesterday with Barisan Nasional and Paktan Rakyat reprensentative engaged in scuffles in an attempt to wrest control of the Chair. The only way Nizar could be dismissed, he said, was through a vote of no-cofidence in the House. He also said that a Menteri Besar could request for the State Assembly to be dissolved in the middle of a term without losing the confidence of the majority of the House. In february, Nizar filed an aplication seeking a declaration that he is the rightful Menteri Besar and an injunction to bar Dr. Zambry from discharging his duties as MB. Dr. Zambry's lawyer Datuk Cecil Abraham, however, argued that Nizar went by Article 16(6) of the Perak Costitution when he sought Perak Constitution an audience with the Sultan- this article specifically provides for the Menteri Besar to request for dissolution when he has 
lost the confidence of the majority in the House. Under the article, Nizar is required to tender the resignation of his executive councillors when his request was rejected, he said (Lisa Goh, 2009). Moreover, it was one of the ugliest secenes in mlaysian state assembly history. There were shouting wars, furious shoving, assemblymen standing on tables and even one grabbing the Speaker's microphone. The dramatic showdown between Barisan Nasional and Pakatan Rakyat assemblymen was to wrest control of the Speaker's Chair (Foong, Koh, Looi, Chan, Teh, Loh \& Singh, 2009). The above statements justified that political status competation between exMenteri Besar and existing former Menteri Besar have been leading social chaos in Perak state.

Consequently, this study aim to find out the factors to stabilize politic for national civilian satisfaction. Thus, the problem statement of this study can be concluded as:

\section{Malaysia”}

"To what extent national civilians unsatisfying current democratic policies in

\subsection{Research Objectives}

The purpose of this study is to examine and find out stability of Malaysia political system through perception of national civilians. For this purpose, four specific objectives will be examined.

- To identify what possible elements and factors can stabilize political system. Currently, our nation is not stable due to civilians are not supporting Barisan National party (BN) fully according to election under national democratic system in 2008. Thus, this study is attempted to review past positive and negative factors or elements that can improve our current political situation.

- To determine which identified elements and factors can stabilize political system in Malaysia. A survey will be done through national civilians to determine what factors and elements are really useful and appropriated to stabilize current political system.

- To identify what factors should be improved to satisfy our national civilians. This survey totally derives from national civilian perception. Thus, it will decide what kinds of factor improvement are really satisfied them to stabilize current political situation. Consequently, this objective is determined that what kind of political system is really satisfying civilians in Malaysia.

\subsection{Significance of the Study}

This study is significant to distinguish between reality of national political system and perception of national civilian regarding our political system. No matter national civilians provide true or false perception, the government should identify or illustrate the real political system for our civilians to let them know actual political system (democracy) in Malaysia. Otherwise, misunderstanding between government's implementation and civilian's perception are still continuing without end point. In addition, this study will capture national civilian's perception about what factors or elements to stabilize our political system. Thus, this study will aware national government to understand the perception of stabilized political system from our national civilians. The government should obey and illustrate current political system to let national civilians know about government implementation are following democratic system in Malaysia.

\subsection{Scope of the Study}

Scope of the content; this particular study will examine only on well-managed and stabilized political system in Malaysia. The factors of well-managed and stabilized political system contain manpower development, economic development and growth, governance, political culture, technology development, security environment and social development through civilian's perception in Malaysia.

Scope of the area; this study would only focus in two states (Perak and Selangor), Malaysia.

Scope of the time; the time has been consumed for this study from 2009 until 2013.

\subsection{Theoretical Framework}

I remember struggling with these same questions as a doctoral student, and even now as a young faculty member assisting future scholars in developing their research skills. Theoretical Frameworks provides direct, practical, and interesting explanations and examples to answer these questions. Even for scholars and practitioners interested in more quantitative research methods, this Introduction provides a useful foundation and an easy to understand explanation of how theoretical frameworks influence research. Each chapter is generally organized in the same manner. Authors provide a brief overview of the study in which the theoretical framework is used; describe the theoretical framework; identify how the framework was discovered in practical and real-world terms; discuss how the framework influenced the research questions, design, and analysis of the study. Theoretical Frameworks is accessible, interesting, and reads like a conversation with the authors of each chapter about the struggles and successes of identifying theoretical frameworks in their work. As I continue to improve my own qualitative and quantitative research skills, and work with graduate students as they prepare to become future scholars, Anfara and Mertz's book will prove to be an essential resource for me. I highly 
recommend this publication to scholars, graduate students, and practitioners exploring civic learning and character education from either a qualitative or quantitative orientation (Molasso, 2006).

According to example given by Sekaran, diagram of the relationship between the independent variable (availability of reference materials) and the dependent variable (rejects) as moderated by the moderating variable (interest and inclination) (Sekaran, 2003). The diagram has shown below:

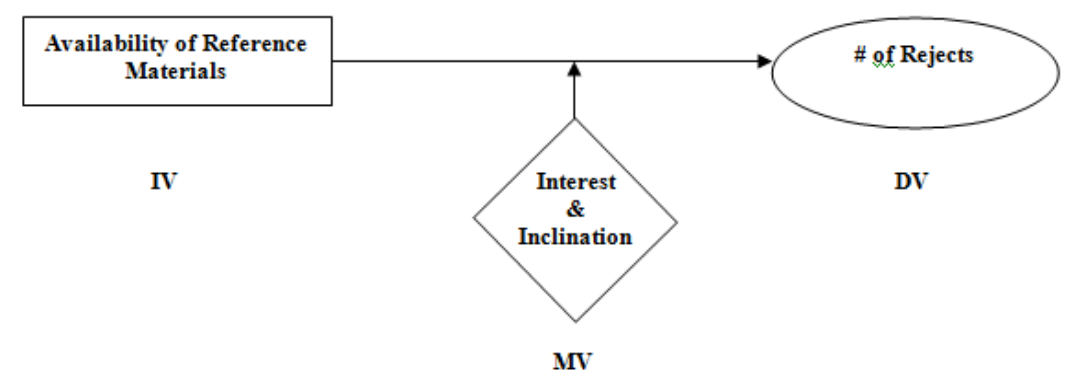

"Figure 1" The model of theoretical framework.

Source: Sekaran (2003).

To illustrate a clear theoretical framework, the below innovated and modified theoretical framework had constructed from Sekaran's model (above mentioned diagram).

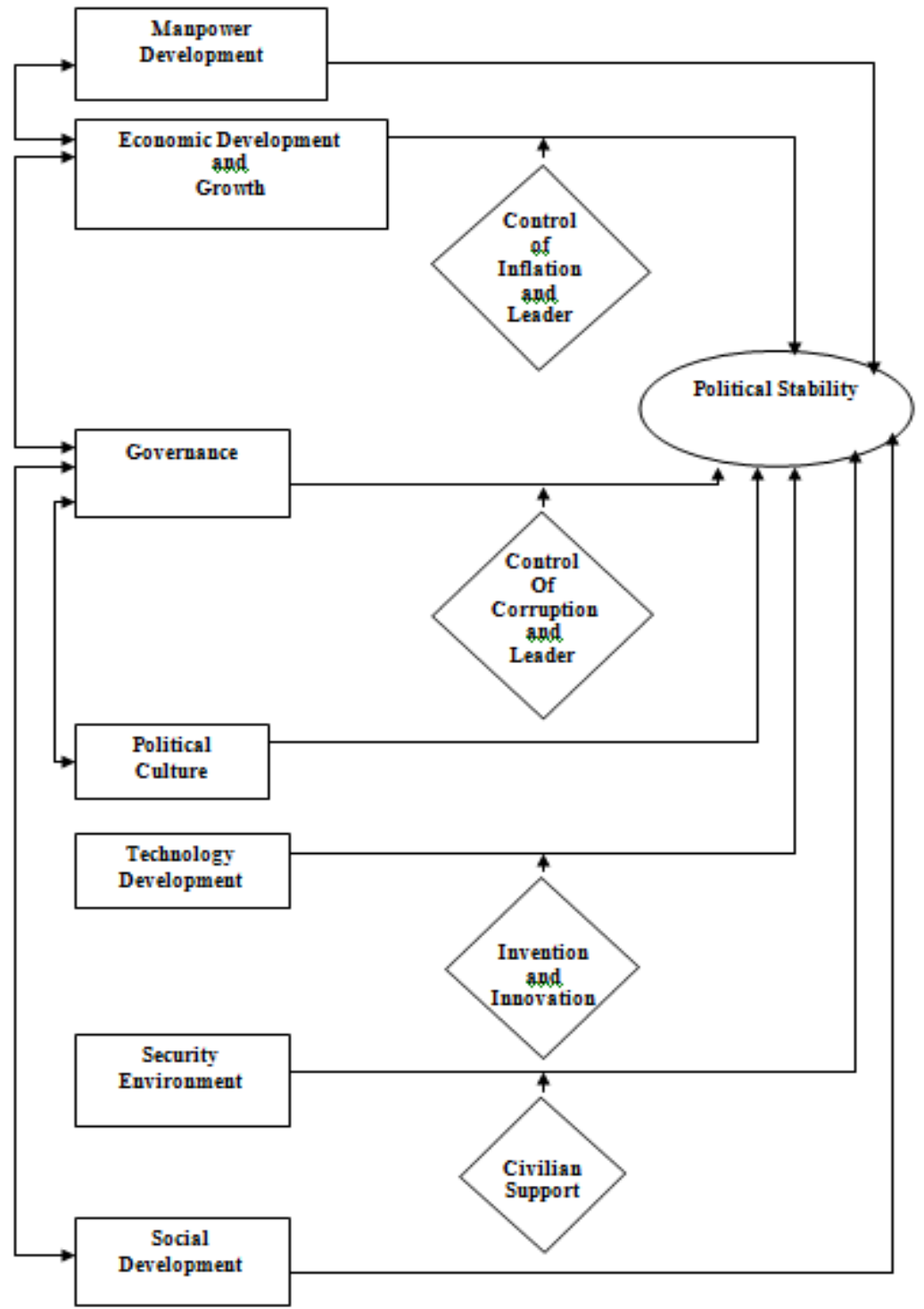


Dependent variable: Political Stability.

Moderate variables: Control of Inflation and Leader, Control of Corruption and Leader, Invention and Innovation and Civilian Support.

Independent variables: Manpower Development, Economic Development and Growth, Governance, Political Culture, Technology Development, Security Environment and Social Development.

Based on the above theoretical framework, manpower development is one of the factors to influence politics. To retain a stabilized political system, manpower development is necessary for a country to achieve the mentioned target. Moreover, manpower and economic development and its growths are related to achieve political stability for a country. The development of manpower and economy are necessary work together to stabilized political system.

Political stability is depended on economic development and its growth. Although stabilized political system is based on economic development and its growth, the stability of politic should be adjusted or regulated by control of inflation and qualified leaders. Hence, inflation adjustment and quality of political and economical leaders could improve and enhance economic development and its growth to stabilize political system. In addition, national governance and economic development and its growth have relationship to achieve political stability in a country. Good governance would bring positive impact to economic development and its growth for a country. Thus, a country's economic development and its growth are depended on good and stabilized governance.

Well-established and stabilized governance could maintain political stability eternally in a country. However, governance has been influencing political system in a country but it still requires control of corruption and qualified politicians to retain its stability. Furthermore, the status of national governance could be influenced by political culture. The relationship between governance and political culture are vital factors to decide stability of political system. In addition, the national governance also has been influencing social development in a country because all social development rules are required to achieve the objectives of national governance. Consequently, the relationship between national governance and social development are important factors to influence political system.

Technology development is one of the factors to influence political system. A stabilized political system is required technology development to improve its efficiency and effectiveness. Moreover, the technology development has been influenced and controlled by new invention and innovational elements to stabilize political system. To achieve a stabilized political system, a country must develop technology development by considering invention and innovation concepts.

Indeed, safety and secure environments in a country could bring positive impact on political system. Thus, the development of safety and secure environment is mandatory in a country. Although safety and secure development is a factor to influence status of political system, a country also needs all civilians or citizens support it. All supportive civilians and citizens could strengthen security environment in a country to stabilized political system.

\subsubsection{Hypotheses}

Hypotheses usually are formulated on the basis of theory and previous research findings. A research hypothesis makes a specific prediction before data are collected. Before collecting data, we have to predict a result of the research. After formulating a hypothesis, researchers collect data to test it and then examine the data to decide if it's valid or not (Kato, 2002).

Non-directional hypotheses are those that do postulate a relationship or difference, but offer no indication of the direction of these relationships or differences. In other words, though it may be conjectured that there would be a significant relationship between two variables, we may not be able to say whether the relationship would be positive or negative. Likewise, even if we can conjecture that there will be difference between two groups on a particular variable, we will not be able to say which group will be more and which less on that variable (Sekaran, 2003).

H1: Manpower development is associated with political stability based on national civilian perception.

H2: Manpower development is associated with economic development and growth based on national civilian perception.

H3: Economic development and growth are correlated to political stability based on national civilian perception.

$\mathrm{H} 4$ : Governance is associated with economic development and growth based o national civilian perception.

H5: Economic development and growth is correlated to control of inflation and leader based on national civilian perception.

H6: Control of Inflation and Leader is correlated to political stability based on national civilian perception. 
H7: Governance is correlated to political stability based on national civilian perception.

H8: Governance is correlated to leader and control of corruption based o national civilian perception.

H9: Leader and control of corruption is correlated to political stability based on national civilian perception.

H10: Political culture is associated with political stability based on national civilian perception.

H11: Governance is associated with political culture based on national civilian perception.

H12: Technology development is associated with political stability based on national civilian perception.

H13: Technology development is associated with invention and innovation based on national civilian perception.

H14: Invention and innovation is associated with political stability based on national civilian perception.

H15: Security environment is associated with political stability based on national civilian perception.

H16: Security environment is associated with civilian support based on national civilian perception.

H17: Civilian support is associated with political stability based on national civilian perception.

H18: Social development is correlated to political stability based on national civilian perception.

H19: Social development is associated with governance based on national civilian perception.

\subsection{Definition of Terms}

The result of this study will determine correlation between stabilized political system and discovered factors and elements via national civilian perception. The stabilized political system will be studied by those discovered factors and elements such as manpower development, economic development and growth, governance, political culture, technology development, security environment, social development, control of inflation and leader, control of corruption and leader, invention and innovation and civilian support. To test the theoretical framework relationship, the below statements were proved by various researchers from literature review.

\subsubsection{Manpower Development}

A researcher, namely Omodia Stephen Monday observed that manpower development is related to socio-economic and political problems in Nigeria. His observation was based on poverty, political instability and economic development. (Monday, 2009).

\subsubsection{Economic Development}

Effective political stability on economic growth aspect is assessed with variables that decide economic growth in theoretical literature. Moreover, capital, labor force and human capital with technology are key economic determinants of economic growth in growth theories (Youni, Xu, Sharahili \& Selvarathinam, 2008). At a time when the country is striving for more economic investment, and to stake out a place on the world stage after September 11, the Gujarat violence has provoked international skepticism about India's commitment to secular ideals and its political stability. But if these events carry a clear lesson, it is that we need a subtler sense of what economic development is doing to India and what political stability means there (Khilani, 2002).

\subsubsection{Control of Inflation \& Leader}

Political instability is an important factor influencing policy makers to push their country to adopt Inflation Targeting. Inflation, Exchange rate volatility, Growth, unemployment didn't have significant effect in this sample. Inflation and unemployment have positive correlation with Targeting (Samimi \& Motameni, 2009). In addition, stability of political system in a country is requiring capable political leaders to manage and regulate it. Leadership is a vital role to manage a country that brought peaceful for a country. One party political system or authoritarian political regime with visionary leadership is more favorable to achieve stability of balance of payment as well as other macro economic objectives (Ali, Tan, Selvarathnam, Xu \& Saboor, 2008).

\subsubsection{Governance}

Based on the research of Geoffrey Evan and Mansur Laljee, they have assumed that talking politics at least sometimes involves talking about issues like social inequality and law and order. This assumption receives implicit support from the fact that there is a relationship between frequency of talking politics and the consistency and stability of left - right and liberal - authoritarian attitudes (Evans \& Laljee, 1997). Preworski and his colleagues have shown that once democracy is established, the level of economic development has a great deal to do with its ability to survive (Seligson, 2000). Thus, economic development and governance are two related factors to influence stability of political system in a country. In the early 1990s fewer than one-fifth of its urban population had attitudes supportive of stable democracy (Seligson, 2000). The way to overcome the challenges to political leadership and political crises in the democratic transition and consolidation in a postdemocratization period is to build a new democratic political model, appropriate for the new democratic law and order. In other words, political leaders and civil society have to accept democratic law and order that were established in the transition period as the only and sole 'rule of game' in politics and have to internalize the 
democratic political procedure and culture in them, on top of institutional and procedural democracy (Lee \& Lee, 2008).

\subsubsection{Control of Corruption \& Leader}

Political stability is a key recipe to combat corruption successfully. The more stable the political situation of a country, the stronger the control of corruption will be. Democratic Countries tend have stronger control of corruption level than those, the non-democratic (Wijayanto, 2007).

\subsubsection{Political Culture}

The increasing availability of survey research data world-wide urges us to carefully examine political culture as factor that may help us understand the prospects for democratic stability (Seligson, 2000).

\subsubsection{Technology Development}

Scholars studying national innovation systems have given considerable attention to knowledge stocks. These results suggest that there is a fundamental relationship between political institutions and technology development. (Waguespack, Birnir \& Schroeder, 2005).

\subsubsection{Invention \& Innovation}

David Matthew Waguespack, J'ohanna Kristin Birnir and Jeff Schroeder were posited that all else equal, one should expect inventors to consider national policy stability as an indicator of economic prospects when deciding whether to engage in inventive activity or seek patents (Waguespack, Birnir \& Schroeder, 2005).

\subsubsection{Security Environment}

Kuwaiti Minister of Interior Lieut-Gen Sheikh Jaber Khalid Al-Sabah said on Thursday (23 October 2008) those previous experiences proved that security was a prerequisite for political stability for any country. He hailed the "noticeable improvement" of the security situation in Iraq which resulted from "sincere efforts and great sacrifices" made by the Iraqi security men nationwide (Roy, 2008).

\subsubsection{Civilian Support}

Civilian populations can play a crucial role in stabilizing inflammatory situations and preserving the foundations of peace. They require the full support of the international community to ensure that, at the very least; our diligent efforts are not detrimental to human security at the individual, family and community levels. Health, education, employment and a viable environmental policy are the next generation of security goals, for they hold out the greatest hope of achieving sustainable peace (Bruderlein, 2001).

\subsubsection{Social Development}

The urban population is more organized and has greater political bargaining power (Lipton 1977; Bates 1981). Because of one or both of the above factors, governments policies in many developing countries tend to be urban biased and reinforce rural-urban disparities. Governments policies in many developing countries tend to be urban biased and reinforce rural-urban disparities. Moreover, China has not exploited fully the employment potential possible given its endowments. Urban residents, through lobbying, have pressured local urban governments into instituting protectionist policies (Cai \& Kam, 2000).

\subsection{Research Questions}

Q1: Does factor of national manpower development to influence current political stability in Malaysia?

Q2: Do national manpower development, and national economic development and growth are related to sustain current political system in Malaysia?

Q3: Do national economic development and growth can stabilize political system in Malaysia?

Q4: Do national governances and economic development and growth relate to support political system?

Q5: Does existing national economic development and growth can be stabilized by existing nation control of inflation and political leaders to support political system in Malaysia?

Q6: Do nation control of inflation and political leaders can stabilize current political system?

Q7: Does national governance can stabilize current political system?

Q8: Do Malaysia governances manage well by current nation political leaders and control of corruption to stabilize political system?

Q9: Do nation political leaders and control of corruption decide political stability in Malaysia?

Q10: Does nation political stability depend on political cultures in Malaysia?

Q11: Do Malaysia governances and political cultures relate to sustain political system? 
Q12: Does technology development can stabilize current political system in Malaysia?

Q13: Does national technology development rely on ideologies of invention and innovation to stabilized political system in Malaysia?

Q14: Do invention and innovation ideologies support political system stability in Malaysia?

Q15: Does security environment can stabilize political system in Malaysia?

Q16: Does Malaysia security environment influence via national supportive civilians?

Q17: Do national supportive civilians consolidate political stability in Malaysia?

Q18: Does nation social development can stabilize current political system?

Q19: Does nation social development relate to Malaysia governances?

\subsection{Introduction}

\section{Literature Review}

Literature Survey is the documentation of a comprehensive review of the published and unpublished work from secondary sources of data in the areas of specific interest to the researcher. The purpose of the literature review is to ensure that no important variable that has in the past been found repeatedly to have had an impact on the problem is ignored. Sometimes it might happen that the investigator spends considerable time and efforts to discover something that has already been thoroughly researched. A literature review would prevent such a waste of resources in reinventing the wheel. However, because every situation is unique, further research has to proceed taking into consideration the relevant variables applicable to it. A good literature survey thus provides the foundation for developing a comprehensive theoretical framework fro which hypotheses can be developed for testing. A good literature survey thus ensures that (1) Important variables that are likely to influence the problems situation are not left out of the study. (2) A clearer idea emerges as to what variables would be most important to consider (parsimony), why they would be considered important, and how they should be investigated to solve the problems. Thus, the literature survey helps the development of the theoretical framework and hypotheses for testing. (3) The problem statement can be made with precision and clarity. (4) Testability and replicability of the finding of the current research are enhanced. (5) One does not run the risk of reinventing the wheel that is, wasting efforts on trying to rediscover something that is already known. (6) The problem investigated is perceived by the scientific community as relevant and significant (Sekaran, 2003).

To stabilized a political system, the establishment of political system consisting various factors and elements. Any changes of the factors or elements may influence the status of political system either in positive or negative ways. Those related factors and elements are manpower development, economic development and growth, control of inflation and leader, governance, control of corruption and leader, political culture, technology development, invention and innovation, security environment, civilian support and social development.

\subsection{Manpower Development}

Manpower development is one of the factors that could stabilize political system. According to Omodia Stephen Monday's observation, he defined it is able to situate or relate what could be referred to as manpower under development to socio-economic and political problems in Nigeria by looking at such factors as poverty, political instability and economic under development (Monday, 2009). A stabilized politic is deemed necessary manpower development for a country based on the proven research by Monday.

\subsection{Economic Development And Growth, Control Of Inflation, And Leader}

The effects of political stability on economic growth are measured with variables which determine economic growth in theoretical literature. Capital, labor and human capital with technology are key economic determinants of economic growth in growth theories. Political stability may have direct effect on growth. But it has a strong effect on sources of capital accumulation (Younis, Xu, Sharahili \& Selvarathinam, 2008). According to the statement of Frank Bohn, it is actually optimal for the current government to totally refrain from spending on public investment, if enough myopia is produced by political instability. As we increase political stability, we reach a threshold above which it is optimal to increase investment. At first, marginal investment is strong, because additional political stability effectively increases the discount factor for the future. Then, however, the additional investment increments become smaller, because marginal investment profitability goes down. In addition, the disregard for private sector decisions on labor, consumption and investment would certainly not be suitable simplifications for industrialized countries, but may be seen as a first approximation in some developing or transition countries, where there is either no economic growth or it depends on external factors (like foreign direct investment) (Bohn, 2003). Indeed, economic development and growth are associated with political system to move a country in a stabilized situation. Regarding to statement of Sunil Khilani, at a time when the country is striving for more economic investment, and to stake out a place on the world stage after September 11, the Gujarat violence has provoked international skepticism about India's commitment to 
secular ideals and its political stability. But if these events carry a clear lesson, it is that we need a subtler sense of what economic development is doing to India and what political stability means there (Khilani, 2002). Moreover, political stability is playing important role in determination of stability of balance of payment. Stable political regime with visionary leadership leads the nation to a higher level of favorable balance of payment. It makes a healthy economic environment to achieve stability of balance of payment (Ali, Tan, Selvarathnam, Xu \& Saboor, 2008). Further economic policy and policy makers have to pay more attention on the political factors to achieve macro stability than economic factors. Singapore, China and Malaysia are good examples for these arguments. India, Sri Lanka, Philippines and Pakistan are good example for that how a political instability with multi party political system negatively affects and destroy the macro economic stability, especially stability of balance of payment and external value of currency (Ali, Tan, Selvarathnam, Xu \& Saboor, 2008). Base on the research of Marija Dzunic, the correlation coefficient between economic growth, the policy of economic reforms and political liberalization is rather high, showing that the countries with the highest index of democratization have realized the highest growth rates. More precisely, the synergic interaction of simultaneous liberalization measures both in economy and politics, has led to positive developments in form of economic progress. On the other hand, positive economic results have a positive counter-effect on the course of democratization process. While economic deterioration enlarges the probability for transition to democracy, mass support for democracy can be obtained with the help of sustainable economic growth and victory over poverty. (Dzunic, 2006). According to the statement of Nauro Campos and Menelaos Karanasos, their main finding is that while "informal" political instability has a direct, negative effect on economic growth, "formal" political instability has mostly an indirect impact (through volatility) (Campos \& Karanasos, 2007). In conclusion, Edgardo E. Zablotsky's paper has proposed the hypothesis that there exists a relation from economic growth to political stability. This hypothesis does not oppose but complement the usual one, which states that political stability is a prerequisite for economic growth. Under our hypothesis the relation between political stability and economic growth has to be understood as a two way relation (Zablotsky, 1996). In addition, Cyprus is a democratic state with consistently high economic growth. In fact, it is already close to meeting the criteria for EMU entry. Its commitment to European values and political stability make it an excellent candidate for membership (Karamanlis, 2000). Obviously, the economic development and growth has authority to influence stability of political situation. Base on the research of Lailani Burra and Md. Ismail Ahmad, Their findings are similar to those of Akoorie and Enderwick (1990) who found that high domestic real interest rates, (non) availability of government export assistance and the ability to finance overseas operations, were among the top five concerns of New Zealand exporters (Burra \& Ahmad, 1991). Furthermore, two main findings have emerged from our empirical analysis, which is based on data of important political events in 30 European countries since 1989. First, we find that political news do more domestic stock markets and increasingly other markets in Europe. In particular, with the introduction of EMU there has been a significant convergence process in that political shocks have increasingly less influence on domestic markets and more and more relevance for foreign markets, underlining the overall financial integration process in Europe (Fratzscher \& Stracca, 2008). Based on the political economy analysis, it provided compensation for those who lose out in this transition to a unified labor market. An integrated labor market, which will allow China to be more efficient and in turn generate economic growth and enlarge the economic pie, should be the goal. To achieve this, the government may want to consider compensating urban workers who lose jobs in this reform and so that they can accept a nondiscriminatory labor market. (Cai \& Kam, 2000). The Probit model indicates that political instability is an important factor influencing policy makers to push their country to adopt Inflation Targeting. Inflation, Exchange rate volatility, Growth, unemployment didn't have significant effect in this sample. Inflation and unemployment have positive correlation with Targeting (Samimi \& Motameni, 2009). In addition, for the political will to be established, the state capacity needs to be strengthened. Engaging more of the civil society and the private sector can be a key piece in the puzzle necessary to implement the necessary measures. The private sector's participation can help build the state and market institutions that will work together to create healthy competition in the economy through standard business practices (Abdullah, 2008).

\subsection{Governance}

Although patronage-based governance is now widely thought to create an unstable political environment, the Africanist literature has shown that leaders can employ patronage to facilitate intra-elite accommodation and thereby stabilize their regimes. A leader can extend his tenure by recruiting more clients into his government even after controlling for variables conventionally used in the study of coups and civil wars in Africa. If a leader wants to lower the risk being deposed, he essentially has two options. He can focus on stimulus the economy in order to raise per capita income, or he can use state resource to buy off key elites (Arrioda, 2008). Therefore, stability of political system in a country is requiring capable political leaders to manage and regulate it. Leadership is a vital role to manage a country that brought peaceful for a country. One party political system or authoritarian political regime with visionary leadership is more favorable to achieve 
stability of balance of payment as well as other macro economic objectives (Ali, Tan, Selvarathnam, Xu \& Saboor, 2008). Regarding to the research of Geoffrey Evan and Mansur Laljee, they have assumed that talking politics at least sometimes involves talking about issues like social inequality and law and order. This assumption receives implicit support from the fact that there is a relationship between frequency of talking politics and the consistency and stability of left - right and liberal - authoritarian attitudes (Evans \& Laljee, 1997). In addition, U.S. diplomatic leadership in Kenya is essential for the stability of a regional power, efforts to fight terrorism in East Africa, and Africa's forward momentum as a democratic continent. The humanitarian component is an important part of the U.S. official response in Kenya, but it is nowhere near sufficient (Woods, 2008). The political crisis prompted by the presidential impeachment was a joint product of a lack of leadership and of clashing interests among major political forces in Korea. At the early stage of his presidency, Roh failed to be a leader of mediation, coordination and consultation (Lee \& Lee, 2008). Regarding to the research paper of George K. Davis and Bryce E. Kanago, they have investigated the possibility that some of the sensitivity is caused by a third variable that affects both inflation and economic growth, political stability. In our sample political stability dominates inflation, real uncertainty, and inflation crisis as explanatory variables of economic growth (Davis \& Kanago, 1998). Consequently, political leaders are vital roles to manage governance, economic development, inflation and growth for political stability in a country. Furthermore, a researcher, Lauren Philips assumed that if governance assessments are to be used to inform aid policy, it is worth investigating the link between political risk, broadly defined to include democratic and institutional attributes, and governance as defined by the donor community (Philips, 2006). Obviously, country governance is associated with political system to reduce political risk. Moreover, regarding to Elo Amucheazi's research, many years of military rule have dislocated the Nigerian society and disorganized the economy and the political system itself. The overall development of the country has been seriously affected and the hope is that the incoming democratic regime will once again set the country along the path of progress. The optimism arises from the development in the political arena. In addition, the Nigerian press and the social movements which have over the past years intensified political struggle are bound to insist on adherence to democratic practices and responsiveness of the government to the needs of the people (Amucheazi, 1999). In addition, the chance of another government being in power and taking undesirable decisions in the future produces a negative spill-over onto today's government. This is the basis for the result of myopic government behavior in the literature (Bohn, 2003). Sunil Khilani also said that the acrid parliamentary debates recommence, Indians are gripped in an ugly paradox: given the presence of religious extremism, coalition governments are most likely to deliver political stability and to protect the rest of India from the purgatorial fate that has befallen Gujarat. But from an economic point of view, coalition governments are least likely to formulate and push through the deeper economic reforms that India must accomplish. India's political stability currently depends on relatively weak coalition governments. Yet, coalition governments are far from ideal when it comes to economic policy and reform. The current coalition has just about been able to maintain the gradual reformist drift that has marked Indian economic policy since 1991 (Khilani, 2002). In addition, Preworski and his colleagues have shown that once democracy is established, the level of economic development has a great deal to do with its ability to survive (Seligson, 2000). Consequently, economic development and governance are two related factors to influence stability of political system in a country. In the early 1990s fewer than one-fifth of its urban population had attitudes supportive of stable democracy (Seligson, 2000). According to the research of H. Emre Bagce, he has intensively referred to the literature, analyzed the advantages and disadvantages of parliamentary and presidential systems, and argued that especially in heterogeneous, developing, and non-consolidated democracies parliamentary system concedes to the "Political Stability" more than presidential system does. Moreover, the design of political institutions in Malaysia has paved the way for consociational politics and so, it contributed to the political stability and alleviated possible religious, racial, and ethnic conflicts (Bagce, 2002). Based on the statement of Marija Dzunic, on the contrary, frequent, but peaceful government turnovers strengthen democratic values, and even though it is necessary to search for compromise all the time, there are potentials for competing interests to involve in the policy-making process and prevent power abuses (Dzunic, 2006). Thus, a peaceful country normally is derived from democratic governance. The initial impetus for The Civic Culture, and for much subsequent work, was a concern about the potential consequences of participation, both positive and negative, for the stability of regimes. In the contemporary celebration of the liberal value of civic participation for democracy there is also a tendency to be complacent about its virtues and to minimize its darker side, for example dangers even in established democracies such as France, Britain and the Netherlands, such as recent cases when initially-peaceful mass protests about government policy have occasionally slid into street violence, looting and the destruction of property, and riots. The other urgent and equally important challenge is to relate individual-level and systems level analysis, to explore not just the drivers of individual behavior but also the consequences of these acts for the political regimes. This includes research identifying the threats to fragile states and what can be done to strengthen effective and practical democratic reforms (Norris P., 2006). In fact, Kenya undertakes the long road back to political stability; the devil will be in the details, from required parliamentary legislation to cabinet 
appointments (Woods, 2008). The empirical evidence of the quality of institutions puts the Andean region in a low place in international rankings of (survey-based) indices of voice and accountability, rule of law, regulatory burden, control of corruption, political instability, and violence, although improvements in some of these governance dimensions have also been observed. This paper highlights the way that governance problems can be decomposed at three levels: the political-constitutional regime, the working of intermediate level institutions, and the patterns of social conflict, inequality and ethnic diversity (Solimano, 2003). Furthermore, democratic consolidation not only requires institutional and procedural democracy, but it also calls for democratic leadership, and democratic attitude and orientation of the civil society. Challenges, not confirming existing laws and regulations, to political leadership and following political crises cause political instability. It is the result of failure to reach an agreement on the rules of political game between political leadership and civil society, and to setup democratic political model. The way to overcome the challenges to political leadership and political crises in the democratic transition and consolidation in a post-democratization period is to build a new democratic political model, appropriate for the new democratic law and order. In other words, political leaders and civil society have to accept democratic law and order that were established in the transition period as the only and sole 'rule of game' in politics and have to internalize the democratic political procedure and culture in them, on top of institutional and procedural democracy (Lee \& Lee, 2008). According to the statement of Kostas Karamanis, genuine democratization and political/economic reform and the abandoning of nationalistic concepts are crucial to a peaceful and prosperous future for the Balkans. Economic and technical assistance to be channeled through the Stability Pact should require that multiethnic tolerance and a deep respect for human rights and democracy be reflected in all activities and processes (Karamanlis, 2000).

\subsection{Control Of Corruption And Leader}

According to the conclusion by Nik Rosnah Wan Abdullah, the results of the CPI and PERC surveys are grim warnings that the anti-corruption drive is not making much headway and there is an urgent need for drastic measures if the battle against corruption is not to be lost altogether. Quah (2003) observes, the critical factor for success is not in the number of anti-corruption measures, but whether these measures are impartially implemented. What is needed is the political will to implement the measures effectively: "Political will is absent when the 'big fish' are protected from prosecution for corruption and only small fish are caught. Under these circumstances, the anti-corruption strategy lacks credibility and is doomed to failure" (Quah, 2003 p. 181) (Abdullah, 2008). In fact, political stability is a key recipe to combat corruption successfully. The more stable the political situation of a country, the stronger the control of corruption will be. Democratic Countries tend have stronger control of corruption level than those, the non-democratic (Wijayanto, 2007). On the other hands, an alternative explanation for appalling levels of public investment in some countries and/or governments' unwillingness to invest in the fight against corruption (Bohn, 2003). Obviously, it shown the corruption must be controlled to stabilize a country political system via regular governance. Furthermore, the discussion of Pakistan, authored by State's Bureau of Democracy, Human Rights, and Labor, does not contain the words "democracy" or "democratic," and notes that the right of citizens to change their government "was restricted in practice." A March 2005 State Department report on human rights and democracy claimed that Pakistan's political parties "are generally weak, undemocratic institutions centered on personalities instead of policies. The judiciary is corrupt, inefficient, and malleable to political pressure (Kronstadt, 2005). The transparency of political process and participation of all social categories reduce incentives for corruption activities, and checks and balances system prevents from power abuse. (Dzunic, 2006). In creating its democracy, Taiwan has attacked "black gold" - the cronyism and corruption that once marked its politics (Graeme Dobell, 2007). Consequently, a stabilized country is required control of corruption from national and governmental governance. The control of corruption should be handled well by political leaders in a country.

\subsection{Political Culture}

The increasing availability of survey research data world-wide urges us to carefully examine political culture as factor that may help us understand the prospects for democratic stability (Seligson, 2000). Indeed, it shown that political culture is related to political system stability in a country. In addition, Costa Rico possesses a combination of political support and political tolerance that augurs well for continued democratic stability. At the other extreme lies Guatemala. In the early 1990s, fewer than one-fifth of its urban population had attitudes supportive stable democracy whereas 68 percents had attitudes that would favor either oligarchy or democratic breakdown (Seligson, 2000). Furthermore, the analysis has also shown that Northern Ireland's best chance for political stability resides in the democratic evolution of its anti-system parties. As SF's political culture evolved and moved away from radical positions it shifted both the pattern of nationalist party competition (centripetal vs. centrifugal) and bridged the ideological distance with the SDLP (Morisi, 2006). In euro regions, the euro should stand up very well. It has two great strengths: a large and expanding transactions size; and a culture of stability surrounding the ECB in Frankfurt. Initially, the EU-11 will be smaller than the dollar area, but as other members 
enter, as the EU expands, and as the poorer countries catch up, the euro area will eventually be larger than the dollar area (Mundell, 1999).

\subsection{Technology Development}

Scholars studying national innovation systems have given considerable attention to knowledge stocks. These results suggest that there is a fundamental relationship between political institutions and technology development. The exact nature of this relationship, what occurs between expectations regarding policy stability and the ultimate granting of intellectual property, remains unknown (Waguespack, Birnir \& Schroeder, 2005). Consequently, technology development in a country is a factor to influence stability of political environment.

\subsection{Invention And Innovation}

Both invention and innovation elements are motivated to stabilize political system from technology development. The researchers, David Matthew Waguespack, J'ohanna Kristin Birnir and Jeff Schroeder were posited that all else equal, one should expect inventors to consider national policy stability as an indicator of economic prospects when deciding whether to engage in inventive activity or seek patents. Our results support this argument and show more specifically that policy stability and consequent rates of patent applications increase roughly in line with predictions of the Veto Players argument. The higher the number of Veto Players in a system the greater the policy stability expected by an inventor and the more likely she is to seek a patent for her invention (Waguespack, Birnir \& Schroeder, 2005). Perhaps the most positive and innovative contribution Greece can make as an EU member is in serving as the anchor of a strategy of stability and regional cooperation in Southeast Europe. Greece is uniquely positioned to do this. It is the only country in the region with membership in the EU, NATO, the Western European Union, and other major international organizations (Karamanlis, 2000).

\subsection{Security Environment}

Regarding to the security environment for political system stabilization, Kuwaiti Minister of Interior Lieut-Gen Sheikh Jaber Khalid Al-Sabah said on Thursday (23 October 2008) those previous experiences proved that security was a prerequisite for political stability for any country. He hailed the "noticeable improvement" of the security situation in Iraq which resulted from "sincere efforts and great sacrifices" made by the Iraqi security men nationwide (Roy, 2008). Security environment is required the full support of the international community to ensure that, at the very least, our diligent efforts are not detrimental to human security at the individual, family and community levels. Health, education, employment and a viable environmental policy are the next generation of security goals, for they hold out the greatest hope of achieving sustainable peace (Bruderlein, 2001). On the other hands, Civilian populations can play a crucial role in stabilizing inflammatory situations and preserving the foundations of peace. They require the full support of the international community to ensure that, at the very least, our diligent efforts are not detrimental to human security at the individual, family and com-munity levels. Health, education, employment and a viable environmental policy are the next generation of security goals, for they hold out the greatest hope of achieving sustainable peace (Bruderlein, 2001). In fact, the settlement of the Cyprus problem is a high priority for Greece and an essential component to long-lasting improvement in Greek-Turkish relations. After all, the perception of a military threat from Turkey has dominated Greek public debate and security planning since the 1974 Cyprus crisis. Greece's mission should be to become an anchor of stability in the Balkans, actively contributing to the prosperity and security of Southeast Europe by promoting regional cooperation in reconstruction and development (Karamanlis, 2000). According to the explanation of Andrew K. Milton and Patrick H. O’Neil, so long as rationalized, bureaucratic state institutions continue to spread throughout the world, the "zone of peace" described by Kant will expand. This is not to say that state institutions cannot be eventually undermined or fragmented by serious economic or political turmoil. However, we believe that these are exceptional rather than typical circumstances. The spread of the modern state and its inherent risk-aversion will be the best guarantee against war in the twenty-first century (Milton \& O’Neil, 2002). Ultimately, security environment might not be ignored due to peace sustainability for a country.

\subsection{Civilian Support}

Civilian support is the stimulation between security environment and political system stability. According to the explanation of Claude Bruderlein, individual and communities should no longer be seen as passive victims of war, waiting for airlifts of food or the establishment of an international criminal court. Civilian populations can play a crucial role in stabilizing inflammatory situations and preserving the foundations of peace (Bruderlein, 2001). In Afghanistan, the call for more talking is recognition that political stability depends on convincing Afghans that their government has the interests of all Afghans at heart. That means 
dealing with those political-military entities outside of government that represent the genuine grievances of Afghans (Regehr, 2006).

\subsection{Social Development}

Perhaps the most fundamental social transformation over the course of the seventeenth century was the consolidation of the political presence of the middling sort in English rural communities. The increasing maturity of parish of. cers in managing inequalities of wealth and power in the countryside effectively transformed rural communities into "parish states," each of them a microcosm of the structures of authority in the realm itself. This is emphatically not to argue that the poor laws were solely responsible for the growth of political stability in Restoration England. It is, however, to suggest that the welfare republics founded to administer the poor laws provided the social and institutional context in which that stability was most often pursued (Hindle, 2000). In addition, the urban population is more organized and has greater political bargaining power (Lipton 1977; Bates 1981). Because of one or both of the above factors, governments policies in many developing countries tend to be urban biased and reinforce rural-urban disparities. Moreover, China has not exploited fully the employment potential possible given its endowments. Urban residents, through lobbying, have pressured local urban governments into instituting protectionist policies. In pre-reform China, the distortions in the factor market and the resulting segmentation of rural and urban labor markets are inherently linked to the industrialization strategy (Chan, 1994; Lin et al, 1996). Those distortions were part of the strategy and system used by China. As argued in the paper, the distortions in the factor market and labor segmentation continue to exist in the reform era (Cai \& Kam, 2000). Indeed, social development is one of the factors to stabilize political system based on the above statements.

\subsection{Introduction}

\section{Materials and Methods}

This chapter discussed about the methods to implement and perform the research. All the ways of collected data, analytical data and results will be presented in this specific part. The measurement of stabilized political system in Malaysia will be investigated through face to face interview to test proposed hypotheses. The identified factors to influence political system including manpower development, economic development and growth, governance, political culture, technology development, security environment and social development will be investigate by applying structured interviewing method. The interviewing instrument has consisted socio- demographic questions and structured questions by the concept of theoretical framework. Seven respondents will be asked through face to face interview for data collection. The qualitative data will be analyzed through comparative analysis from seven respondents. Consequently, this chapter will explain all the planed ways such as study design, data collection method, structural interviewing questions and data analysis methods that will be executed for this study. The entire procedure for this study will be presented as following:

1. Study Design

2. Data Collection Method

3. Structured Interviewing Questions

4. Questionnaire Structure

5. Data Analysis Methods

\subsection{Study Design}

This research is mainly to discover what elements and factors to stabilize political system via perception of national civilians. Qualitative research can be undertaken prior to a survey to identify key topics for inclusion in a questionnaire. In addition, qualitative research may be undertaken too based on a quantitative study to explore reasons for the results (Clark, 2009). Qualitative research, begins with an intention to explore a particular area, collects "data" (observations and interviews), and generates ideas and hypotheses from these data largely through what is known as inductive reasoning. The strength of qualitative research lies in validity (closeness to the truth) - that is, good qualitative research, using a selection of data collection methods, really should touch the core of what is going on rather than just skimming the surface (Clark, 2009).

Qualitative research was originally developed in the social sciences, but has been more common since the mid-1990s in medicine, nursing, psychology, political science, social work and education. Qualitative research uses non-numerical data to explore how humans behave, experience and understand (Clark, 2009). As a construct for qualitative methodologists, validity has been a site of tension and struggle. Validity is often understood as the ability to accurately measure what one sets out to measure. This understanding is problematic on two counts. First, as Geertz (1973) notes, human interaction while patterned is not predictive, which makes measurement between any two instances of human interaction difficult at best. Second, the purpose of qualitative research is most often not to measure but come to some understanding what such interactions mean 
(Agar 1986; Erickson 1986) (Gershon, 2008). Moreover, Researchers who use qualitative methods seek a deeper truth. They aim to "study things in their natural setting, attempting to make sense of, or interpret, phenomena in terms of the meanings people bring to them," and they use "a holistic perspective which preserves the complexities of human behaviors (Greenhalgh \& Taylor, 1997)." Indeed, this research is appropriated to apply qualitative methods due to the above identified statements.

\subsection{Data Collection Method}

This research will be implemented through primary data collection approach. According to the Sekaran explanation, primary source of data is apart from the individuals who provide information when interviewed, administered questionnaire, or observed at length under Data Collection Methods (Sekaran, 2003). For this intention, a survey will apply face to face interview to conduct the census of Malaysia civilians in Perak and Selangor states.

One method of collecting data is to interview respondents to obtain information on the issues of interest. Interviews could be unstructured or structured and conducted either face to face or by telephone or online. The questions are likely to focus on factors that had surfaced during the unstructured interviews and are considered relevant to the problem. As the respondents express their views, the researcher would note them down. The same questions will be asked of everybody in the same manner (Sekaran, 2003). Obviously, the above statements are guiding this research intends to apply structured interview as survey instrument to collect data from appropriated respondents by using same questions. The intention of the research only chooses seven respondents randomly in Perak and Selangor states, Malaysia. Those respondents will be involved majority Malay and Chinese races individually.

\subsection{Structured Interviewing Questions}

Structured interviews are those conducted when it is known at the outset what information is needed. The interviewer has a list of predetermined questions to be asked of the respondents either personally, through the telephone, or through the medium of a PC (Sekaran, 2003). For this research, the structured interview will be applied through face to face interview. The interviewing questions consist of two sections. Section A has a set of social- demographic questions whereas section B has a set of questions designed by the concept of the theoretical framework in this research.

\subsection{Sampling Design}

Qualitative researchers rarely draw a representative sample from a huge number of cases to intensely study the sampled cases. Qualitative researchers tend to use nonprobability or non-random samples. This means they rarely determine the sample size in advance and have limited knowledge about the larger group or population from which the sample is taken (Neuman, 2006). Based on the fact, this study intends to select seven respondents as interviewees by applying nonprobability sampling. This study will only choose seven respondents as interviewees contains Malays and Chinese races and their ages between 21 to 65 in two states, Perak and Selangor. Both male and female respondents are involved in this research.

\subsection{Data Analysis Methods}

Analytic comparison will be applied to examine qualitative data for this research. The data will be analyzed from seven respondents where were mentioned previously by using analytical comparison. The British philosopher and theorist John Stuart Mill (1806-1873) developed logic of comparison that is still in wide use today. His method of agreement and method of difference form the basic for analytic comparison. Analytic comparison uses a quasi-experimental approach that combines deductive with inductive theorizing. Basically, a researcher identifies many factors for a set of cases, sorts through logical combinations of factors, and compares them across cases. The real strength of analytic comparison is that it helps researchers identify the combination of factors, often measured at nominal level, that are associated with an outcome among a small number of cases (Neuman, 2006). The above statements are suitable for this study. Thus, this study intends to select comparative analysis as data analysis methods

\subsection{Summary}

This chapter were planed and explained step by step in detail to show how the researcher answers the identified research questions. The planed procedure in this chapter includes study design, data collection method, structured interviewing questions, sampling design and data analysis methods are decided to test hypotheses and answer the research questions. The finding of this research will be performed in the fifth chapter based on those defined procedures in this chapter. 


\section{Area Study in Malaysia}

\subsection{Introduction}

This particular chapter is showing general structure and public policy in Malaysia. The region in Malaysia will be studied mainly through national demographic, ethnic, politic, economic development and social development. The detail will be exposed following below:

\subsection{Demographic}

Malaysia's total population currently stands at approximately 22.8 million of which approximately 21.5 million qualify as citizens (Mid-term Review of the Seventh Malaysia Plan (MTR7MP), 1999, Table 4.1). The population is projected to increase at an average annual rate of $2.2 \%$, with a growth rate for those aged 65 and above estimated at 4.1\% (MTR7MP, 1999, Table 4.1). Life expectancy in Malaysia has continued to increase from 68.8 years for males and 73.4 years for females in 1991 (Asher, 1994), to 69.6 years for males and 74.5 years for females in 1997 (MTR7MP, 1999, Table 12.3) (Caraher, 2000).

\subsection{Ethnic}

The population of Malaysia comprises the three major ethnic groups of Asia- the Chinese, Indians and Malays. In Peninsular Malaysia (where 80 per cent of the population lives), about 61.1 per cent are Malays (Department of Statistics 2001a). The Malays, together with a small group of the other indigenous groups, are known as the Bumiputra, or son of the soil. The Chinese and Indians make up about 27.4 per cent and 9.4 per cent of the population of Peninsular Malaysia respectively. They are the descendants of migrants from China and India in the early part of the twentieth century. The remaining 0.7 per cent is "Others". Each ethnic community has maintained its own socio-cultural ways of life, and is segregated to some extent by place of residence, education and occupation. With increased rural-urban migration, about two-thirds of the population now lives in urban areas, compared with just $25 \%$ in the 1960s. In the past, most Malays were in the rural areas and engaged in agricultural activities, while the non- Malays were mainly in the urban areas. However, the Malays have been urbanising rapidly in line with the objectives of the economic policies implemented since 1970. The urbanisation rate of the Malays increased to about 54 per cent in 2000, up from about 15 per cent in 1970. During the same period, the rate of urbanisation of the Chinese and Indians has increased from 47 to 87 per cent and 35 to 80 per cent respectively (Tey, 2002).

\subsection{Politic}

Malaysia is a South-east Asian nation with a population of 25 million (2003 estimate). It constitutes two regions i.e. Peninsular Malaysia (situated south of Thailand) and the 2 largest states of Sabah and Sarawak referred to as East Malaysia - separated by the South China Sea and located at the north of Borneo island. A total of 15 states make up the country, each with their respective elected state governments. The federal government is a parliamentary democracy comprising a House of Representatives (elected) as well as a Senate (appointed). Malaysia also has a constitutional monarchy. The nation attained independence from Britain in August 1957 and in the 46 years as a sovereign nation, has achieved much economic and social progress (Mat \& Taha, 2003).

\subsection{Economic Development}

With a per capita income of about RM13000 (\$US=RM3.8) Malaysia is classified by the World Bank as an upper-middle income country. The expansion of the economy and the implementation of specific programmes have reduced the incidence of poverty to 7.5 per cent in 1999. Nevertheless, wide variations in the economic conditions still exist. The incidence of poverty of 12.4 per cent in the rural areas is significantly higher than the level of 3.4 per cent in the urban areas. The average household income in the rural areas is estimated at RM1718 compared to RM3103 in the urban areas. Household income also varies widely across ethnic groups, ranging from RM1984 among the Bumiputra, RM2704 among the Indians and RM3456 among the Chinese (Malaysia 2001) (Tey, 2002).

\subsection{Social Development}

Malaysia has achieved remarkable progress in social development, with improvement in educational level, health status and the standard of living. Primary education has become universal. In 1998, enrolment in primary school and secondary school is 95\% and 58\% respectively (Department of Statistics 1999). The educational profile of the labour force shows that the proportion with tertiary education is $13 \%$ compared to only $3 \%$ in 1980 . There are narrower gender differentials in educational attainment and the female labour force participation rate has remained at around 47 per cent (Department of Statistics, 2001c). In 1970 slightly more than half of the labour force were employed in agriculture, but this has declined to 15 per cent in 2000. On the other hand, the proportionate share of employment in the manufacturing sector has increased from 8 per cent to 
28 per cent during the same period. Significant gains have also been made in the construction, services and financial sectors. The occupational structure varies substantially by ethnic group-about 21.5 per cent of the Malay labour force in 2000 was engaged in agriculture, compared with 15.1 per cent among the Indians and 6.5 per cent among the Chinese (Department of Statistics 1983; and Malaysia, 2001) (Tey, 2002).

\subsection{Interviewed Solutions \\ Interviewee: 1}

V. Findings \& Results

Recently, I interviewed a doctor to collect vital information regarding to my study. Her name is Dr. Tan Ming Shiuan (age 32) from Tanjung Bunga, Penang. She is a Chinese race and working at KO Skin Specialist Medical Centre, Klang. Her answers are based on below attached interviewing questions. Unfortunately, she only answered my interviewing questions from question one to question eleven. Nevertheless, she also provided important information about her perception to explain our national political stability.

Q1: Do you think political stability in Malaysia require organizational manpower development? Why?

Answer:

She said that manpower development is necessary to stabilized politic in Malaysia. It can be increased and enhanced if manpower development has been improved. Majority organizational manpower development is relied on certain experts and professional persons. They can improve national both economy and society if they are willing to implement it based on their skills or knowledge to stable our political system. Obviously, she agreed that national economy and society will be improved if organizational manpower development is implemented smoothly and also improving political stability naturally and indirectly.

Q2: How to improve political system through organizational manpower development in Malaysia?

Answer:

Fostering skillful employees or staffs is one of the vital ways to improve political system in Malaysia. According to Dr. Tan Ming Shiuan explanation, national manpower development can be enhanced through specific training program for new employees and staffs to enhance their skills or knowledge. After that, their skills and knowledge can be contributed for various economy fields and social fields in Malaysia. Our country can utilize them to satisfy national civilian's requirement until they support fully our political system.

Q3: Do you think manpower development, economic development and growth are related to stabilize political system in Malaysia? Why?

Answer:

A stabilized economy development in a country always attracts foreign investors attempting to invest their funds in the particular country. A well governmental policy contains different professional politicians under well organizational manpower development to manage national economy. In fact, a stabilized political system in Malaysia really needs those professional politicians to handle well our economy and always convince civilians support the current political system permanently.

Q4: Do you think economic development and growth can influence status of political system in Malaysia? Why? Answer:

In Dr Tan Ming Shiuan's opinions, capital resource is the vital role to consolidate political system in Malaysia. If our fundamental economy is stabilized, national civilians will always initiatively to support our political system.

Q5: How to improve existing economic development and growth to stabilize political system in Malaysia? Answer:

In Malaysia, a fair economic policy is necessary to treat all enterprises fairy to improve existing quality of products and services. Moreover, Economists should invest more funds in research and development. Research and development should be implemented by our government sector to assist small and medium enterprises in Malaysia. Government could provide extra subsidies and incentives for small and medium enterprises to stimulate our economic development and indirectly the stimulation would consolidate our political system.

Q6: Do you think economic development and growth, and national governance is related to stabilize political system in Malaysia? Why?

Answer: 
The main purpose of governance is provided a direction to all civilians follow democratic system strictly and fairly. In Malaysia, our governance is matured to benefits civilians to move in correct way. The mentioned benefits normally related to our economy development.

Q7: Do you think national politicians, economists, and control of inflation can improve current economic development and growth to stabilize political system? How?

Answer:

National politicians and economists are policy makers to influence our country development. If national control of inflation is not controlled well, lower and middle income civilians will ensure to change existing political system and its government. Thus, a group of wise politicians and economists must focus and concern on any governmental policies properly and strictly against inflation problem before launches to society and civilians.

Q8: Do you think political stability require national governance in Malaysia? Why?

Answer:

National political stability depends on the factor of human potential obeying governance to enforce and control governmental policies. If they are well controllers, national stability of politic will be more stable. Otherwise, our political system will not be stable if the controllers are not well to drive our governance.

Q9: How to stabilize political system through democratic system in Malaysia?

Answer:

Democratic system is preferred to civilian's voices no matter what types of political party. They always listen to civilian's voices. Obviously, our politicians must listen civilian's voices sincerely and cater appropriate implementation to solve their problems. In conversely, oppositional party is also played an important role to defend civilian's interest if current controlling party is not managed well political system for the civilians.

Q10: Do you think national politicians and control of corruption can improve current governance to stabilize political system? How?

Answer:

When corruption is widely spreading in the whole country, a lot of funds would not be utilized in proper way to develop and improve existing society and civilian's lifestyle. Our politicians should be self-managed peoples to provide efficiency, trustworthy and free of corruption to obey fully our governance for existing politic.

Q11: Do you think political culture can influence status of political system in Malaysia? Why?

Answer:

Our country is consisting multi-culture politicians to administrate our political system. Different cultural politicians have their owned cultural mindset to foster various political cultures according to their races in Malaysia. Thus, those politicians have their owned ways and opinions to manage and influence our political system.

Interviewee: 2

Mr. Amir Abdullah (age 31) is a personal bodyguard at KO Specialist Medical Centre, Klang. He is a Malay race and his hometown from Klang where locates in Selangor state. He is my second interviewee to provide his perception about politic system in Malaysia.

Q1: Do you think political stability in Malaysia require organization manpower development? Why?

Answer:

He was mentioned that all political parties have their own committees for election. The members in their own parties are required to work together as a team for the victory of election. Hence, they need structural manpower development to enhance their abilities especially communication skills and leadership skills to against other parties in election. Definitely, Mr Amir Abdullah agreed with the organizational manpower development is mandatory to stabilize political system in Malaysia due to victory of election is relied on the abilities of political parties. Moreover, He also mentioned that political experts and professional members can be imported from other countries to assist and train local politicians as a solution for manpower development enhancement.

Q2: How to improve political system through organizational manpower development in Malaysia?

Answer:

Economy development and its growth can be varied if product price in marketplaces are not under controlled properly. Our country is required capable politicians and economists to control suppliers in current marketplaces because consumers are suffering to their low income problem. Those capable politicians and economists are 
relied on the factor of organized manpower development. Basically, our civilians are not satisfied to the political system due to its low income problems to confront increasing product prices in local marketplaces which is related to our current economy development. Naturally, civilians are not satisfying our political system indirectly. Moreover, jobless is a normal issue in Malaysia. Majority graduated students could not get a suitable job in Malaysia. These civilians are protesting current political system. Currently, our country is providing various skills training programs to enhance their ability to compete in various workplaces. Obviously, we are focusing and improving manpower development to influence current political system in a better future.

Q3: Do you think manpower development, economic development and growth are related to stabilize political system in Malaysia? Why?

Answer:

In addition, Mr Amir Abdullah also agreed with economy development and its growth can influence existing political system in Malaysia. He said if our economy in downturn, local civilians would evaluate the performance of existing political parties on economical administration issue. In Malaysia, political parties are controlling and guiding local political system. Hence, economy downturn will guide national civilians against political parties where political system relying on those benchmarked political parties.

Q4: Do you think economic development and growth can influence status of political system in Malaysia? Why? Answer:

The first major action should be taken to stabilize local economy is the anti-corruption issue. Our country should establish a political driving organization to observe and surveillance each and everywhere departments which are related to economy industrials for political system stabilization.

Q5: How to improve existing economic development and growth to stabilize political system in Malaysia?

Answer:

National economy distribution should be administrated fairly for Malay, Chinese and Indian races without boundaries. If our economy partition does not distribute fairly through various races, our civilians will not support our existing political system sincerely. Current government also has to treat civilians fairly without racial discrimination. Conversely, racial - tension may be happened including economy distribution between races also may be affected.

Q6: Do you think economic development and growth, and national governance is related to stabilize political system in Malaysia? Why?

Answer:

At the same time, national governance is relied on constitution that treated Malay race better than other races including Chinese and Indian race. Our constitution is consisting Muslim priority as prime benefits for Malay race. According to Mr Amir Abdullah's viewpoint, government should concern on all races simultaneously without discrimination however our governance gave prime benefit for Malay race in Malaysia.

Q7: Do you think national politicians, economists and control of inflation can improve current economic development and growth to stabilize political system? Why?

Answer:

In Malaysia, politician such as prime minister is an economist involving in financial planning for the country. He has the priority to control our economy for civilians. Economy solution and planning always decide by our prime minister to deal with economical inflation problem. Currently, our politicians may not handle well economical inflation problem in Malaysia. To improve existing economical inflation problem, we need more capable economists in the future due to political system is relied on national politicians and well control of inflation.

Q8: Do you think political stability require national governance in Malaysia? Why?

Answer:

At this moment, Malaysia governance is right for our civilians and we do not need to amend existing governance that consisting constitution. The Malay and Islamic status are the fact to manage our country formally. Political stability is relied on national governance directly without any doubt in Malaysia.

Q9: How to stabilize political system through democratic system in Malaysia?

Answer:

All national civilians have priority to voice up against unfair governmental activities. To stabilize political system, they have the right to voice up if they found unfair or unsatisfied activities were launched from existing 
government. All civilians could protect their properties and life through democratic system to against unfair governmental parties in Malaysia.

Q10: Do you think national politicians and control of corruption can improve current governance to stabilize political system? How?

Answer:

To stabilize our political system, our government should offer opened tenders for all national companies without corruption interference. Currently, our governance always offers tenders for certain companies who have been established good relationship between politicians and companies at top-management. Those particular companies might utilize corruption way for the politicians during tender agreement. To solve the problem, our politicians have to obey our governance fully to make a transparency policies regarding tender arrangement.

Q11: Do you think political culture can influence status of political system in Malaysia? Why?

Answer:

All countries are consisting political cultures influenced by its constitutions. Our country, Malaysia also has its own political culture after independent. Majority political parties against each other parties to gain victory of election. Each member of internal party might affect its dignity of party if any one of the members voice up negative opinions via civilians. Thus, opponent parties would attack them mentally to protect the properties of civilian. Moreover, national civilians also could evaluate internal party administration and influence their status to retain current political system through next election.

Q12: Do you think national governance and political culture are related to stabilize political system in Malaysia? Why?

Answer:

Lord Reid was attempted to illustrate a skeleton of constitution for Malaysian including three major races such as Malay, Chinese and Indian races before independent in 1957. He created a set of constitutions what he believed was suitable for all Malaysian during his living period. Intuitively, political culture was born in that time until now however we have been passed through for 56 years since Independence Day in1957. Of course, stabilized political system in Malaysia depends on existing political cultures due to historical facts were influenced our political culture since 1957. On the other hands, the ideology of opponent parties sometimes provides alternate opinions against constitutional governance while they seeking limitation of our constitution may affect the human right of civilian. The purpose of opponent parties are tried to amend our constitution to confuse civilians. Those mentioned attitudes were existed as political culture in Malaysia since 1957.

Q13: How to stabilize political system by political culture in Malaysia?

Answer:

All political parties may provide their own ideology for the country without sensitive issues especially about Muslim priority in Malaysia. Those parties have their right to fight for victory of election in the boundary of harmony. Aggressive action should be prevented as well as possible through cooperation between various political parties. All parties should concern on sensitive issues rationally to prevent racial - tension happening in Malaysia because our status of political system can be varied without racial - tension prevention and attention. In addition, all parties must treat sensitive issues maturely and do not give radical comments and critics until destructive action happen in Malaysia.

Q14: Do you think political stability can be influence by technology development? Why?

Answer:

In Mr. Amir Abdullah's opinion, technology development can influence political system stability in Malaysia due to all current issues easily spread widely by various technological media for all civilians. They may evaluate current government administration based on internet news and live channels on Television. Mainstream media normally present current issues about positive impact on government side. It shows all about positive actions and results to convince civilians and let them always support current political party. Civilians may provide positive evaluation for the government. Indirectly, the status of Malaysia political system may preserve longer in the future.

Q15: How to improve national technology development to stabilize political system?

Answer:

To improve current political system, latest technology has to be applied from time to time where all current issues can be spread faster and widely to all civilians and let them know what is happening in our country. It may convince civilians as fast as possible base on latest technology. 
Q16: Do you think new invention and innovation can enhance technology development to stabilize political system in Malaysia? How?

Answer:

Latest technologies always replace current technologies rapidly because the improvement of the facility could attract civilians apply new technologies. Our country is using and applying wireless technology now to provide more conveniences know about our political system. Last time, we had to use limited wired technology to access internet but now we can access internet via wireless technology. Civilians could simply view and search various current issues through internet without boundary. Many civilians could evaluate our governmental performance either support current party or against it base on fastest technology.

Q17: Do you think political stability is based on national security environment? Why?

Answer:

The relationship among political parties may be enhanced if all parties are really caring about civilians without racial discrimination. All civilians may live in secured environment if all political parties always provide positive opinions and ideas to improve civilian's lifestyle without discrimination.

Q18: How to consolidate security environment to stabilize political system in Malaysia?

Answer:

National government should not restrict any media to offer latest news for civilians. They should treat media in neutral way without prejudice. So, all media can offer true issues and news for civilians and let them evaluate current performance of government. Civilians can either critic or praise our government through internet service without aggressive activities especially physical protestation. At the same time, government also should listen civilian's voice and improve society until they still support current government and the political system.

Q19: Do you think our security environment require all civilians and citizens support it to maintain political stability? How?

Answer:

National civilian alliance should be organized without concerning political background, religions and races. Our government should provide working places and market places without racial discrimination. In addition, the relationship between police enforcements and civilians should be established through governmental planning and execution.

Q20: Do you think political stability require social development in Malaysia? Why?

Answer:

Civilians always request fundamental requirements such as educational scholarship or sponsorship, personal insurance, financial loan and others to improve their lifestyle. They are not willing to live in suffering country without governmental assistance. If their fundamental requirements are satisfied from governmental assistance, they still may continue support existing government and its political system.

Q21: How to improve existing social development to stabilize political system in Malaysia?

Answer:

Government has to use national funds wisely to help civilians. They must arrange and manage national funds properly to avoid corruption. National funds can be used in social development smoothly without corruption interference. On the other hands, government can consolidate MACC (Malaysian Anti-Corruption Commission) to avoid corruption happen on civilians as victims.

Q22: Do you think national governance and social development are related to stabilize political system in Malaysia? Why?

Answer:

Before the year 1969, NEP or called New Economy Policy had not existed yet in Malaysia. Racial properties did not arrange properly during that period. Consequently, unfair racial properties arrangement appeared a big gap between Malay race and Chinese race. After the year 1969, NEP was launched by our second prime minister, Tun Abdul Razak who attempted to solve problem of unfair racial properties arrangement successfully until now. In fact, Malaysia must contain a person in-charge who born in Malay race in any multinational enterprises. Without NEP, Malay race might still not satisfy current racial properties arrangement. In addition, All races in Malaysia would trust our political system if racial priority has been declared fairly through constitution. 
Interviewee: 3

My third interviewee has reached over 60 years old. His name is Lim Chin Who and also is a Chinese race. Currently, he lives in Klang where he born at the same hometown in Selangor state, Malaysia. Moreover, he was retired since seven years ago.

Q1: Do you think political stability in Malaysia require organizational manpower development? Why?

Answer:

Organizational manpower development is the backbone of political stability in Malaysia. Due to manpower development could train professional staffs, workers or employees under political parties, our country would be well-administrated from those trained professional persons. They would provide professional ideologies to assist civilians until those civilians satisfy our political system.

Q2: How to improve political system through organizational manpower development in Malaysia?

Answer:

A political manpower development could illustrate positive images through marketing strategies for civilians. Normally, civilians are willing to obey and agree our political system while various positive images from different governmental departments already performed well in society.

Q3: Do you think manpower development, and economic development and growth are related to stabilize political system in Malaysia? Why?

Answer:

If manpower development has been consolidated strong enough, all trained political parties would manage our economy more efficient. Economy development would be improved to bring better lifestyle for civilians. Thus, civilians will always support our political system if they are living in satisfied conditions in Malaysia.

Q4: Do you think economic development and growth can influence status of political system in Malaysia? Why? Answer:

While economy recession in Asia happened in 1997, Malaysia also affected during that particular year. Commenced from 1997, not all Malaysian fully been supporting our political party until the election in 2008 was lost several seats. In fact, our economic development directly influenced our political system.

Q5: How to improve existing economic development and growth to stabilize political system in Malaysia? Why? Answer:

All civilians must cooperate together without racial discrimination to obey fully our economical policies based on our political system. All civilians must work together too to thrive our economy based on political policies that launched from politician's strategies.

Q6: Do you think economic development and growth, and national governance are related to stabilize political system in Malaysia? Why?

Answer:

National governance has priority to decide the fate of economic development in Malaysia. Malay race priority has primary benefits in Malaysia indirectly influence other races to develop national economy. Consequently, the stability of political system is depended on economic development either by fairness governance or viceversa.

Q7: Do you think national politicians, economists and control of inflation can improve current economic development and growth to stabilize political system? How?

Answer:

Opponent parties should always observe all implementation of politician and economist. In addition, control of inflation also should be observed by opponent parties too if they found current political party provided prejudice ideologies against civilians and economic development. Our political system would be more stable while the implementation of existing political party and critical statements of opponent party are worked together.

Q8: Do you think political stability require national governance in Malaysia? Why?

Answer:

Our government has to spread our governance widely through the entire country. All civilians require transparent governance to let them truly understand it. A well-structured political system must be understood by all national civilians. 
Q9: How to stabilize political system through democratic system in Malaysia?

Answer:

Political parties must implement all governmental plans based on democratic system without racial discrimination. Moreover, the government also has to treat all enterprises fairly by democratic system. Our government hopefully do not just focus on Malay race but ignoring other races especially Chinese race in economy development.

Q10: Do you think national politicians and control of corruption can improve current governance to stabilize political system in Malaysia? How?

Answer:

First at all, national politicians must be self- discipline persons because the effectiveness of corruption control is based on self - discipline politicians to manage it. At the same time, self - discipline politicians would like to prevent corruption fully to improve our political system.

Q11: Do you think political culture can influence status of political system in Malaysia? Why?

Answer:

No matter a political culture either in positive way or negative way, the status of political system also would be influenced either positive implication or negative implication. It depends on politicians either self - positive attitude manners or self - negative attitude manners to manage our political system.

Q12: Do you think governance and political culture are related to stabilize political system in Malaysia? Why?

Answer:

National governance has been established since1957; it has been concerned more on Malay races regarding their interests and status in Malaysia. Therefore, other race's status especially Chinese and Indian races were not compared with Malay race in Malaysia. In fact, our political culture consisting unfair issues for each discussion in Parliament. To solve race's issues in Malaysia, all politicians have to treat and assist civilians based on their races. Otherwise, racial discrimination would be happened in Malaysia because unfair treatment between races requirement.

Q13: How to stabilize political system by political culture in Malaysia?

Answer:

All politicians have to be neutral to work and discuss together without racial- discrimination. Moreover, our politicians also have to discuss together to protect civilian's life and interests fairly.

Q14: Do you think political stability can be influenced by technology development? Why?

Answer:

Technology development could offer more job vacancies for civilians. In fact, technology development naturally enhances our political system while majority civilians have their own satisfied careers in Malaysia.

Q15: How to improve national technology development to stabilize political system?

Answer:

We have to improve current technologies through innovative ideologies due to innovative ideologies always attract foreign investors willing to invest their funds in innovative technologies. Thus, we can utilize the foreign funds to develop those innovative technologies in smoothly stream. Latest technologies can spread our political issues for all civilians widely and faster by various electronic media. They can evaluate our government by those innovative technologies.

Q16: Do you think new invention and innovation can enhance technology development to stabilize political system in Malaysia? How?

Answer:

Technological invention and innovation is the factor to propose marketing strategy in Malaysia. The marketing strategy directly attracts civilians replace used technologies. The velocity to spread political issues always in improvement situation while marketing strategy is fully implemented for all civilians. Civilians can receive political issues in faster and easy way to understand current political situation. In fact, civilians can evaluate our political system as fast as possible by the new inventive and innovative technologies. 
Q17: Do you think political stability is based on national security environment? Why?

Answer:

Civil chaos may be happened without a security environment for civilians. Civil chaos may influence our political system directly. The first criteria to live in a country are a safety environment for civilians.

Q18: How to consolidate security environment to stabilize political system in Malaysia?

Answer:

To consolidate our security environment, we have to implement democratic system seriously. All civilians have their priorities to voice up their suffering issues through political parties. Each political party must protect and assist their races based on the suffering issues. If each political party is really can provide solutions for the suffering issues, our civilians will support existing political system in the future.

Q19: Do you think our security environment require all civilians and citizens support it to maintain political stability? How?

Answer:

Government can propose various public protections for civilians regarding to their race's requirement. Each political party has to observe civilians to understand what the really problem happening in the society. Each political party can propose various solutions regarding to security issues. Once civilian's life and properties were secured, they would support current political system without any doubts because each civilian requires a secured environment to protect his or her family and life.

Q20: Do you think political stability require social development in Malaysia? Why?

Answer:

Social development is necessary to stabilize our political system. Due to our government has been catered a lot public facilities such as primary and secondary school establishment, public highway establishment and train lane establishment in Malaysia, national civilians could live in a proceeding country based on the mentioned effective social development. In fact, civilians are surely to support current government and political system.

Q21: How to improve existing social development to stabilize political system in Malaysia?

Answer:

A stabilized political system requires diplomatic strategies. In Malaysia, our government can propose various diplomatic strategies to attract and negotiate foreign investors attempting invest their funds in our country. Thus, national politicians can utilize those funds to develop our national society. A proceeding society will always encourage civilians support current political system because civilians can live in a facilitated environment which catered by existing government.

Q22: Do you think national governance and social development are related to stabilize political system in Malaysia? Why?

Answer:

The relationship between governance and social development are concerned on fair treatment for all civilians including Malay, Chinese and Indian races. However, our governance is focusing on major Malay prime priority; government also has take care other races because they are living in Malaysia too. Therefore, government must be provided various public facilities developing our society for all races simultaneously without racial discrimination. If our government more concern on social development for Malay race by our governance accordingly, other races may not satisfy less current social development in Malaysia.

Interviewee: 4

Mr. Tan Piaw Young (age 34) is a motorcycle technician in Ipoh, Perak state. He has a motorcycle shop in Ipoh as a businessman and he is a Chinese race too. He was willing to accept my interview to provide his viewpoints about political perception in Malaysia.

Q1: Do you think political stability in Malaysia require organizational manpower development? Why?

Answer:

Both enterprise and political party are required human resource to train well-perform experts for next generation in their related working fields. Normally, trained person can gain highly income easily in Malaysia. Thus, if majority civilians have chances to be trained persons, they surely still support our government and existing political system because they do not worry about their financial problems through highly income policies. 
Q2: How to improve political system through organizational manpower development in Malaysia?

Answer:

Top management in each political party and enterprises has their intention to train new generation to be experts for their future from time to time. So, retired employees and low-performed employees can be replaced by trained new employees no matter in political field or business fields.

Q3: Do you think manpower development, and economic development and growth are related to stabilize political system in Malaysia? Why?

Answer:

Each enterprise and political party has their owned experts to manage and arrange their owned businesses and country respectively and independently. If they are well-manage in their working fields, our economy and politic performance will be improved and enhanced naturally. At the same time, civilians will satisfy and praise our political system based on those mentioned well-perform economy and politic.

Q4: Do you think economic development and growth can influence status of political system in Malaysia? Why? Answer:

Currently, our government is not guiding our political system well enough especially economic development. Majority civilians are not satisfied about low-income problem in various business fields. In my viewpoint, majority civilians may not fully support existing political system due to financial problem in their life.

Q5: How to improve existing economic development and growth to stabilize political system in Malaysia?

Answer:

Governmental revolution is the right time to stabilize our political system. Opponent party has to give a chance to perform their ideologies in economy development for civilians and let civilians to evaluate them according to their political performance.

Q6: Do you think economic development and growth, and national governance are related to stabilize political system in Malaysia? Why?

Answer:

Our economic policies are fully depended on national governance continually. The implementation of economic development and its growth is based on our governance. If our politicians are not obeyed governance, they may lead our economic development in negative way to perform negative implication for civilians.

Q7: Do you think national politicians, economists, and control of inflation can improve current economic development and growth to stabilize political system? How?

Answer:

Basically, our economic development is not managed well by current politicians, economists and control of inflation strategies. Opponent political party may treat all races fairly. Thus, the improvement may require governmental revolution by new political party in the next election. To stabilize our political system, opponent party may give a chance to lead our country.

Q8: Do you think political stability require national governance in Malaysia? Why?

Each country has its owned governance. Malaysia also has its owned governance to lead civilians. Our civilians require democratic system without racial-discrimination.

Q9: How to stabilize political system through democratic system in Malaysia?

Answer:

To stabilize political system in Malaysia, governmental politicians have to treat all civilians fairly without racial-discrimination. Any public facilities must be provided regarding their race's requirement through fairness democratic system.

Q10: Do you think national politicians and control of corruption can improve current governance to stabilize political system? How?

Answer:

National politic system requires governance strictly and fairly against both political corruption and civilian's corruption. We need honor politicians to obey governance against corruption without racial-discrimination and political status. Our politicians have to amend governance to treat corruption strictly and fairness justice for all civilians and politicians. 
Q11: Do you think political culture can influence status of political system in Malaysia? Why?

Answer:

Political corruption and racial-discrimination issues are major elements in our political culture. Obviously, civilians are not fully supported our political system due to mentioned negative implication of political culture.

Q12: Do you think national governance and political culture are related to stabilize political system in Malaysia? Why?

Answer:

The source of political culture was established since 1957 from structural governance. All different racial politicians have been working together so many years in the same political culture to manage our political system. This situation will go on continually from one generation to next generation.

Q13: How to stabilize political system by political culture in Malaysia?

Answer:

Tolerance issues between all races are the first step to be improved in our political culture. Due to our political system requires no racial-discrimination between politicians, all different race of politicians have to tolerance each other to manage our political system in stable line.

Q14: Do you think political stability can influence by technology development? Why?

Answer:

Yes of cause. Without technology development, political party is difficult to spread political issues, activities and implications for civilians. Those civilians, are not fully received political information from political party and government without technology development.

Q15: How to improve national technology development to stabilize political system?

Answer:

We can utilize latest technologies no matter those technologies either from local or import from foreign countries to develop our economy to improve civilian's lifestyle. If our civilians are living in a good economical environment, they still would support our political system without any changes.

Q16: Do you think new invention and innovation can enhance technology development to stabilize political system in Malaysia? How?

Answer:

Local civilians can utilize their knowledge and ideas to invent and innovate new technologies. They may also attempt to develop new technologies in political fields. Local politicians can apply the new technologies to spread any political issues and activities in faster ways.

Q17: Do you think political stability is based on national security environment? Why?

Answer:

In Malaysia, criminal issues always occur via civilians directly. Our government always cater various security system physically and virtually to protect civilians. In addition, government also increases additional security systems to reduce crime activities as less as possible. That security implementation already decided the fate of sustainability of political system in the future because civilians still would support current political party once their life had protected.

Q18: How to consolidate security environment to stabilize political system in Malaysia?

Answer:

Government shall concern on public security on civilian's living areas. That public security must be arranged without racial-discrimination. If our government really can protect civilian's life, they still will support current political party and the system too.

Q19: Do you think our security environment require all civilians and citizens support it to maintain political stability? How?

Answer:

Government can propose more security systems on civilian's living areas and local societies to protect their life. Malaysians are threatened by various criminal activities everywhere. So, local civilians request government provides more security forces on their living places and societies to reduce crime activities in Malaysia. If majority civilian's life is protected, they surely satisfy our political system while their life and families are staying on safe zone. 
Q20: Do you think political stability require social development in Malaysia? Why?

Answer:

Majority civilians are low-income in Malaysia. They need assistance especially financial problems in societies from our government. If our government proposes various public facilities for the societies, civilians surely praise and support our existing government.

Q21: How to improve existing social development to stabilize political system in Malaysia?

Answer:

Current political party is not well-performed in social development. Civilians request opponent party replaces existing political party. They hope opponent party will manage our societies better than current political party.

Q22: Do you think national governance and social development are related to stabilize political system in Malaysia? Why?

Answer:

The policies of social development are relied on governance. National governance should contain a set of laws to declare policies of social development in a fairness way for all civilians consistently. Thus, local social development would be implemented fairly by politicians for all civilians. Our civilians could receive governmental benefits without racial-discrimination based on fairness policies of social development. Local civilians would still support our political system while government providing fairly benefits for all civilians in social development

Interviewee: 5

Mr. Wong Chin Pooi (age 25) is my fifth interviewee for this present study. He is a spare spark advisor and his race is Chinese. Currently, he is living in Ipoh, Perak state. He also accepted interview to cater his opinions about political system in Malaysia.

Q1: Do you think political stability in Malaysia require organizational manpower development? Why?

Answer:

It depends on current political party either willing to discuss and negotiate with civilian's problems or make decision by politicians regarding to organizational manpower development. In addition, it also depends on politicians and enterprises willing to discuss about research for manpower development. If political party, civilians and enterprises are prepared to invest and research in manpower development, our political system will be more stabled.

Q2: How to improve political system through organizational manpower development in Malaysia?

Answer:

Accepting civilian's ideas and opinions is the main way to improve our political system. National politicians should accept civilian's perception to enhance manpower development. The cooperation between politicians and civilians can discover strengths and weaknesses of manpower development to decide our political system in stable line or vice-versa.

Q3: Do you think manpower development and economic development and growth are related to stabilize political system in Malaysia? Why?

Answer:

Economy development is related to manpower development because economy development requires civilian's knowledge and skills to gain profits for the country. In Malaysia, we need civilian's knowledge and skills to develop our economy. If our economy is staying in good condition, our political system will be more stabled due to no unsatisfying in financial problems between government and civilians.

Q4: Do you think economic development and growth can influence status of political system in Malaysia? Why? Answer:

The status of economic development could change civilian's mindsets. Politicians are difficult to lie on them because they could differentiate between worth financial conditions and worse financial conditions in Malaysia. If our economic development is consolidated enough, civilians still will vote current political party for next general election.

Q5: How to improve existing economic development and growth to stabilize political system in Malaysia? Answer:

Both national politicians and civilians must be well-known investors to invest their funds in right choices. 
Q6: Do you think economic development and growth, and national governance is related to stabilize political system in Malaysia? Why?

Answer:

A set of consolidated governances are consisting conflict statements between races in Malaysia. Our governance is concerned on Malay race more than Chinese race and Indian race in Malaysia regarding economic distribution. In Malaysia, economic development, and its growth and national governance are not related to stabilize our political system.

Q7: Do you think national politicians, economists and control of inflation can improve current economic development and growth to stabilize political system? How?

Answer:

Both politicians and economists have to alert themselves involving in corruption as major step to improve economic development in Malaysia. Politicians have to propose pricing policies to control service and product prices in markets. Meanwhile, national economists have to apply their knowledge to control inflation that affecting civilian's lifestyle. If both politicians and economists are taken their responsibilities, civilians will praise our current government and support it permanently.

Q8: Do you think political stability require national governance in Malaysia? Why?

Answer:

Civilians are relied on right and appropriated governance in a country. In fact, Malaysia is also confronting same situation.

Q9: How to stabilize political system through democratic system in Malaysia?

Answer:

All races must be tolerance and worked together without racial-discrimination though actual democratic system. We need the real democratic system to solve political issues in Malaysia.

Q10: Do you think national politicians, and control of corruption can improve current governance to stabilize political system? How?

Answer:

Government and politicians must well-known and sensitive through civilian's perception. Both government and politicians have to amend governance by civilian's perception from time to time which is appropriated for that trend. In addition, fairness and justice elements are necessary under control of corruption. To stabilize our political system, government and politicians have to treat control of corruption strictly.

Q11: Do you think political culture can influence status of political system in Malaysia? Why?

Answer:

All political implementation for civilians depend on civilian's reaction either positive or negative implication. Civilians are able to evaluate political culture by that particular implication in Malaysia and directly influence our political system for next general election.

Q12: Do you think national governance and political culture are related to stabilize political system in Malaysia? Why?

Answer:

Harmonic political culture requires ethical politicians as well as national governance is fairness to treat all civilians. Obviously, both national governance and political culture are related to stabilize our political system while civilians are supporting it regarding to harmonic political culture.

Q13: How to stabilize political system by political culture in Malaysia?

Answer:

Government has to reduce political corruption as a good image for civilians. Moreover, government and political parties should not over utilize priority through civilians. Both statements would establish harmonic political culture and provide good image to let civilians support our political system.

Q14: Do you think political stability can be influence by technology development? Why?

Answer:

Internet technology could easily spread political issues for everyone and getting responses instantly. Civilians could utilize current technologies to evaluate our political system instantly. 
Q15: How to improve national technology development to stabilize political system?

Answer:

Freely utilization is the key point to apply technologies by civilians. They could evaluate political party's performances freely regarding to technology applications.

Q16: Do you think new invention and innovation can enhance technology development to stabilize political system in Malaysia? How?

Answer:

Government can provide good remuneration for information technology experts and engineers to restraint them working in other countries. We need their knowledge and innovative ideologies to develop national technologies.

Q17: Do you think political stability is based on national security environment? Why?

Answer:

A good conditional security environment can reduce victims appearing in a country. Each civilian would support a peaceful political system in a country.

Q18: How to consolidate security environment to stabilize political system in Malaysia?

Answer:

Government shall increase human capital in armed forces. Government also needs to enhance anti-corruption policies and strategies to prevent corruption in politics. In addition, government servants must change their working attitudes in positive way.

Q19: Do you think security environment require all civilians and citizens support it to maintain political stability? How?

Answer:

All civilians must have patriotism mindsets to respect our country. They also are willing to be volunteers in armed forces to protect country. Moreover, both civilians and police forces should be cooperated together to cultivate a peace environment in Malaysia.

Q20: Do you think political stability require social development in Malaysia? Why?

Answer:

Public facility provision is the key point to reduce unsatisfying issues between races in Malaysia. Our civilians would support our political party if they develop the societies without racial-discrimination issue.

Q21: How to improve existing social development to stabilize political system in Malaysia?

Answer:

First step, political conflict should be prevented between races. Government and civilians must always cooperate to decide suitable social development to avoid unnecessary implementation. It will save a lot of financial expenditures for the country.

Q22: Do you think national governance and social development are related to stabilize political system in Malaysia? Why?

Answer:

Unfair governance would establish prejudice social development in Malaysia. Thus, national governance must give a right direction to let politicians implement social development without negative implication for civilians.

Interviewee: 6

My sixth interviewee is working in Singapore but he was worked in his hometown, Ipoh, Perak state two years ago as mechanic. His name is Chaw Kein Fong (age 28) and he also a Chinese race. He was willing to provide his viewpoints regarding to national political issues in this study.

Q1: Do you think political stability in Malaysia require organizational manpower development? Why?

Answer:

To stabilize our political system, we need more professionals and experts in Malaysia. Currently, we do not have enough human capital to execute our political problems. 
Q2: How to improve political system through organizational manpower development in Malaysia?

Answer:

Politicians must be open-minded strategies to develop human capital. We have to train all races consistently without racial-discrimination.

Q3: Do you think manpower development and economic development and growth are related to stabilize political system in Malaysia? Why?

Answer:

Economic development requires a lot of civilian's knowledge and skills to enhance economic growth. If civilians are living in good conditional economy, Malaysia will be more proceeded in financial industry but it is not related to political system. Political system is concerned on human factor but not decided by economic development.

Q4: Do you think economic development and growth can influence status of political system in Malaysia? Why? Answer:

If economic growth is under stable conditions, civilians would live in better lifestyle but their lifestyle quality is not influenced our political system. Certain civilians could do their businesses to gain profits without government assistance.

Q5: How to improve existing economic development and growth to stabilize political system in Malaysia?

Answer:

Government must provide various contributions for civilians in open-minded strategies without racialdiscrimination in Malaysia.

Q6: Do you think economic development and growth, and national governance is related to stabilize political system in Malaysia? Why?

Answer:

We have to respect our governance because we are living in Malaysia. In fact, our economic development must obey our governance. This is the way to prove patriotism in Malaysia.

Q7: Do you think national politicians, economists and control of inflation can improve current economic development and growth to stabilize political system? How?

Answer:

Different politicians, economist and control of inflation strategies are consisted various solutions to confront economic problems in Malaysia. They can provide alternative ideologies together to improve our political system.

Q8: Do you think political stability require national governance in Malaysia? Why?

Answer:

Governance has a set of administrative ways to lead civilians since established in1957. The historical politicians already decided appropriated governance to treat all civilians in Malaysia to sustain political system.

Q9: How to stabilize political system through democratic system in Malaysia?

Answer:

Both politicians and civilians have to obey national laws according to national democratic system. This is the only way to stabilize our political system.

Q10: Do you think national politicians, and control of corruption can improve current governance to stabilize political system? How?

Answer:

National politicians and civilians have to restraint their attitude involving in corruption. In addition, they also need to support our anti - corruption agency to reduce corruption spreading in whole Malaysia.

Q11: Do you think political culture can influence status of political system in Malaysia? Why?

Answer:

Our political culture basically retained since 1957 until now without any obviously changes. Our political system retained the same situation depending on our political cultures. 
Q12: Do you think national governance and political culture are related to stabilize political system in Malaysia? Why?

Answer:

Governance is the source to lead politicians directly. Obviously, politicians could build and retain political culture while obeying our governance.

Q13: How to stabilize political system by political culture in Malaysia?

Answer:

Our political system is stable currently. Current political culture is appropriated and right to influence our political system.

Q14: Do you think political stability can be influence by technology development? Why?

Answer:

Technology development could provide convenience and fast way to spread political issues for civilians. So, they could get instant information to evaluate our political party and government.

Q15: How to improve national technology development to stabilize political system?

Answer:

Civilians can freely provide their innovative ideas for governmental sector to develop technology for our country.

Q16: Do you think new invention and innovation can enhance technology development to stabilize political system in Malaysia? How?

Answer:

Government can foster many experts in technological industry and also absorb latest invented and innovated information from foreign countries to innovate new technologies in our country.

Q17: Do you think political stability is based on national security environment? Why?

Answer:

Security environment contains armed force, security force and police force to protect civilians in a country.

Q18: How to consolidate security environment to stabilize political system in Malaysia?

Answer:

Government can utilize technological security system to enhance security environment in civilian's living areas. In addition, government also has to recruit more civilians in armed force and police force to protect our country.

Q19: Do you think security environment require all civilians and citizens support it to maintain political stability? How?

Answer:

In Malaysia, many civilians involving in armed forces and police force as volunteers. They are supportive peoples in current political party and government because their incomes from government. Thus, our government can purpose more remuneration in armed force and police force to attract more civilians joins with our armed forces and police force.

Q20: Do you think political stability require social development in Malaysia? Why?

Answer:

Government and current politicians offered many public facilities in social development for civilians. Many civilians are utilizing current public facilities from government offered.

Q21: How to improve existing social development to stabilize political system in Malaysia?

Answer:

Government can renew and replace public facilities from time to time to reduce civilian's complaints through our government and political party.

Q22: Do you think national governance and social development are related to stabilize political system in Malaysia? Why?

Civilians always deal with government regarding public deficiency in social development. Government have to obey our governance to develop public facilitates in the societies. Although civilians propose various opinions in social development, government also has to evaluate those ideas either obeying our governance or vice-versa. 
Interviewee: 7

My seventh interviewee is a Malay race and his name is Mr. Mohd. Khairul Bin Zainal (age 28). He is a security officer in Klang, Selangor state but his hometown from Kuala Pilah, Sembilan state. Currently, he is working at a security company called Shapadu. He is a low-educated person but he is willing to provide his viewpoints about our political system.

Q1: Do you think political stability in Malaysia require organizational manpower development? Why?

Answer:

An organizational manpower development is very important for Malaysians because we are chasing our vision in the year 2020 to improve our country as developed country with highly technologies and stable economies. The development of manpower also could enhance competitive politic between political parties in Malaysia regarding to achievement of general election.

Q2: How to improve political system through organizational manpower development in Malaysia?

Answer:

Government can offer higher remuneration for civilians. It can implement campaign through internet facility to illustrate higher remuneration policies under manpower development for all civilians. In addition, government also can launch new polices in business industry to increase civilian's remuneration that proposed in manpower development. Thus, all civilians can solve their personal finance problems easily by the new remuneration policies and support our political system.

Q3: Do you think manpower development and economic development and growth are related to stabilize political system in Malaysia? Why?

Answer:

Government always intend and concern on organizational manpower development and economic development simultaneously to prove our country has a set of effective rules to manage well in manpower development and economic development as a good image globally.

Q4: Do you think economic development and growth can influence status of political system in Malaysia? Why? Answer:

Economic development and its growth is the source to improve civilian's lifestyle in Malaysia. If their lifestyles are stayed in good conditions, they will not change our current political system due to their satisfied lifestyle achieved by current governmental management.

Q5: How to improve existing economic development and growth to stabilize political system in Malaysia?

Answer:

Government can reduce current taxations especially vehicle tax and land tax. Those particular taxations already provide burdens for civilians currently. Moreover, government also can provide loans for civilians to open businesses freely in Malaysia.

Q6: Do you think economic development and growth, and national governance is related to stabilize political system in Malaysia? Why?

Answer:

Current political party always wastes national funds to organize political campaigns for winning in general election without obeying fully our governance. In addition, current political party also always wastes a lot of times in public speaking to hope all civilians vote it in general election.

Q7: Do you think national politicians, economists and control of inflation can improve current economic development and growth to stabilize political system? How?

Answer:

Both national politicians and economists are well-known in economic development. They already improve national civilian's lifestyle by economic development after 2020 vision has been launched until today. National leaders can teach civilians in political knowledge through electronic media to let them understand our political issues and political situation from time to time including political news. In addition, national leaders can reduce and control product prices in markets to reduce civilian's financial burdens.

Q8: Do you think political stability require national governance in Malaysia? Why?

Answer: 
Political stability is the way to prove capable leaders to manage well in a country. It also proves local civilians are satisfied about their lifestyle in a country by the effectiveness of governance.

Q9: How to stabilize political system through democratic system in Malaysia?

Answer:

Democratic system could allow government to organize political campaigns through public speaking to let civilians understand current situation in Malaysia and prevent misunderstanding between political implementation and civilian's requirement in Malaysia. Government could organize live channel about public speaking for all civilians about social problems, political problems and effective improvement and planning to reduce misunderstanding about current political party.

Q10: Do you think national politicians, and control of corruption can improve current governance to stabilize political system? How?

Answer:

Anti-corruption commission was established to arrest people in corruption. Our top national politicians must strictly instruct national Anti-Corruption Commission to arrest any suspects in political corruption. It can reduce losing national funds for civilian's facilities.

Q11: Do you think political culture can influence status of political system in Malaysia? Why?

Answer:

Current political culture always threatens races through public speaking especially racial-conflict issues in Malaysia. It might lose seats in general election to influence current political system in negative way.

Q12: Do you think national governance and political culture are related to stabilize political system in Malaysia? Why?

Answer:

Political culture and national governance are not related due to political decision is under political culture directly influence our economic recession but the political culture does not fully follow national governance. In addition, our politicians contain different races have their owned authorities to provide benefits according to their races until racial-conflicts without obeying governance.

Q13: How to stabilize political system by political culture in Malaysia?

Answer:

Our political cultures can be improved if all politicians are willing to help each other's between political parties. All political parties must focus on local civilian's problems as priorities but not winning for general election.

Q14: Do you think political stability can be influence by technology development? Why?

Answer:

Our government and enterprises were proposed and provided various technologies in the markets. Many civilians utilized current technologies as a trend in Malaysia. Without the technology development, civilians will not support current political system because civilians have been utilized it as a culture in Malaysia.

Q15: How to improve national technology development to stabilize political system?

Answer:

Government can introduce various information technology courses for civilians to learn about it and let them following information technology trend globally. Civilians can obtain information technology skills to develop national technologies to improve our political system.

Q16: Do you think new invention and innovation can enhance technology development to stabilize political system in Malaysia? How?

Answer:

Experts under information technology can invent and innovate new technologies and propose the new technologies in governmental sector. Our governmental sector can launch the latest invention and innovation in technological markets for all civilians. Hence, civilians have a chance to apply latest technologies to improve current technologies as a trend to enhance the image of technology development in Malaysia.

Q17: Do you think political stability is based on national security environment? Why?

Answer: 
A save and peaceful environment allows political campaigns execute safely in Malaysia. Thus, safety environment is the basic requirement for civilians to live in Malaysia. They always support a political party that focusing safely environment as first consideration.

Q18: How to consolidate security environment to stabilize political system in Malaysia?

Answer:

Government can recruit more civilians involve in armed force. Our government also can offer extra remuneration for volunteers under reserve armed force.

Q19: Do you think security environment require all civilians and citizens support it to maintain political stability? How?

Answer:

Government sector can instruct security forces in political campaigns to prevent civil chaos happening in Malaysia. The civil chaos will destruct political system. Thus, government has to protect our civilians injuring in general election and political campaigns because we still need them to support our political system from time to time depending on improvement of civilian's problems in the future.

Q20: Do you think political stability require social development in Malaysia? Why?

Answer:

Governmental social developments attempted to control and restrict western cultures influencing national civilians. Current political party has been proposed various traditional cultures to influence our civilians in the societies and changed their mindsets in ethical issues. Government already implemented various social developments to mature civilian's mindsets. We need our civilians respect and obey our constitutions and national governance to preserve political stability in long term planning.

Q21: How to improve existing social development to stabilize political system in Malaysia?

Answer:

Government, political party and enterprises are required to provide political lessons under social development for civilians in various ways including electronic media and educational policies.

Q22: Do you think national governance and social development are related to stabilize political system in Malaysia? Why?

Answer:

The collaboration between local races is one of the laws under our governance. Thus, government has to develop our societies without racial discrimination. In addition, government also needs to take responsibilities in social development regarding to racial-conflicts in social development due to national governance consisting declared distribution for all races in Malaysia.

\subsection{Comparative Analysis and Results}

Hypothesis 1: Manpower development is associated with political stability based on national civilian perception.

"Table 1" The significant of manpower development factor and political stability factor relationship in Malaysia.

\begin{tabular}{|c|l|}
\hline $\begin{array}{l}\text { Interviewed } \\
\text { respondents }\end{array}$ & \multicolumn{1}{|c|}{ Reasonable Perceptions } \\
\hline Interviewee 1 & $\begin{array}{l}\text { Majority organizational manpower development is relied on certain experts and } \\
\text { professional persons. They can improve both national economy and society if they are } \\
\text { willing to implement it based on their skills or knowledge to stable our political system. } \\
\text { Obviously, she agreed that national economy and society will be improved if } \\
\text { organizational manpower development is implemented smoothly and also improving } \\
\text { political stability naturally and indirectly. }\end{array}$ \\
\hline Interviewee 2 & $\begin{array}{l}\text { Political parties have their own committees for election. The members in their own } \\
\text { parties are required to work together as a team for the victory of election. Hence, they } \\
\text { need structural manpower development to enhance their abilities especially } \\
\text { communication skills and leadership skills to against other parties in election. }\end{array}$ \\
\hline Interviewee 3 3 Organizational manpower development is the backbone of political stability in Malaysia. \\
$\begin{array}{l}\text { Due to manpower development could train professional staffs, workers or employees } \\
\text { under political parties, our country would be well-administrated from those trained } \\
\text { professional persons. They would provide professional ideologies to assist civilians until } \\
\text { those civilians satisfy our political system. }\end{array}$ \\
\hline
\end{tabular}




\begin{tabular}{|c|c|}
\hline Interviewee 4 & $\begin{array}{l}\text { Both enterprise and political party are required human resource to train well-perform } \\
\text { experts for next generation in their related working fields. Normally, trained person can } \\
\text { gain highly income easily in Malaysia. Thus, if majority civilians have chances to be } \\
\text { trained persons, they surely still support our government and existing political system } \\
\text { because they do not worry about their financial problems through highly income policies. }\end{array}$ \\
\hline Interviewee 5 & $\begin{array}{l}\text { It depends on current political party either willing to discuss and negotiate with civilian's } \\
\text { problems or make decision by politicians regarding to organizational manpower } \\
\text { development. In addition, it also depends on politicians and enterprises willing to discuss } \\
\text { about research for manpower development. If political party, civilians and enterprises are } \\
\text { prepared to invest and research in manpower development, our political system will be } \\
\text { more stabled. }\end{array}$ \\
\hline Interviewee 6 & $\begin{array}{l}\text { To stabilize our political system, we need more professionals and experts in Malaysia. } \\
\text { Currently, we do not have enough human capital to execute our political problems. }\end{array}$ \\
\hline Interviewee 7 & $\begin{array}{l}\text { An organizational manpower development is very important for Malaysians because we } \\
\text { are chasing our vision in the year } 2020 \text { to improve our country as developed country with } \\
\text { highly technologies and stable economies. The development of manpower also could } \\
\text { enhance competitive politic between political parties in Malaysia regarding to } \\
\text { achievement of general election. }\end{array}$ \\
\hline $\begin{array}{l}\text { Interviewed } \\
\text { Respondents }\end{array}$ & \\
\hline Interviewee 1 & $\begin{array}{l}\text { Fostering skillful employees or staffs is one of the vital ways to improve political system } \\
\text { in Malaysia. National manpower development can be enhanced through specific training } \\
\text { program for new employees and staffs to enhance their skills or knowledge. }\end{array}$ \\
\hline Interviewee 2 & $\begin{array}{l}\text { Jobless is a normal issue in Malaysia. Majority graduated students could not get a } \\
\text { suitable job in Malaysia. These civilians are protesting current political system. } \\
\text { Currently, our country is providing various skills training programs to enhance their } \\
\text { ability to compete in various workplaces. }\end{array}$ \\
\hline Interviewee 3 & $\begin{array}{l}\text { A political manpower development could illustrate positive images through various } \\
\text { marketing strategies for civilians. }\end{array}$ \\
\hline Interviewee 4 & $\begin{array}{l}\text { Top management in each political party and enterprises has their intention to train new } \\
\text { generation to be experts for their future from time to time. So, retired employees and } \\
\text { low-performed employees can be replaced by trained new employees no matter in } \\
\text { political field or business fields. }\end{array}$ \\
\hline Interviewee 5 & $\begin{array}{l}\text { Accepting civilian's ideas and opinions is the main way to improve our political system. } \\
\text { National politicians should accept civilian's perception to enhance manpower } \\
\text { development. The cooperation between politicians and civilians can discover strengths } \\
\text { and weaknesses of manpower development to decide our political system in stable line or } \\
\text { vice-versa. }\end{array}$ \\
\hline Interviewee 6 & $\begin{array}{l}\text { Politicians must be open-minded strategies to develop human capital. We have to train } \\
\text { all races consistently without racial-discrimination. }\end{array}$ \\
\hline Interviewee 7 & $\begin{array}{l}\text { Government can offer higher remuneration for civilians. It can implement campaign } \\
\text { through internet facility to illustrate higher remuneration policies under manpower } \\
\text { development for all civilians. In addition, government also can launch new polices in } \\
\text { business industry to increase civilian's remuneration that proposed in manpower } \\
\text { development. Thus, all civilians can solve their personal finance problems easily by the } \\
\text { new remuneration policies and support our political system. }\end{array}$ \\
\hline
\end{tabular}

Hypothesis 2: Manpower development is associated with economic development and growth based on national civilian perception.

“Table 2" The significant of manpower development factor and economic development and its growth factor relationship to stabilize political system in Malaysia.

\begin{tabular}{|l|l|}
\hline $\begin{array}{l}\text { Interviewed } \\
\text { Respondents }\end{array}$ & \multicolumn{1}{|c|}{ Reasonable Perceptions } \\
\hline Interviewee 1 & $\begin{array}{l}\text { A well governmental policy contains different professional politicians under well } \\
\text { organizational manpower development to manage national economy. In fact, a stabilized } \\
\text { political system in Malaysia really needs those professional politicians to handle well our } \\
\text { economy and always convince civilians support the current political system permanently. }\end{array}$ \\
\hline
\end{tabular}




\begin{tabular}{|l|l|}
\hline Interviewee 2 & $\begin{array}{l}\text { If our economy in downturn, local civilians would evaluate the performance of existing } \\
\text { political parties on economical administration issue. In Malaysia, political parties are } \\
\text { controlling and guiding local political system. Hence, economy downturn will guide } \\
\text { national civilians against political parties where political system relying on those } \\
\text { benchmarked political parties. }\end{array}$ \\
\hline Interviewee 3 & $\begin{array}{l}\text { If manpower development has been consolidated strong enough, all trained political } \\
\text { parties would manage our economy more efficient. Economy development would be } \\
\text { improved to bring better lifestyle for civilians. Thus, civilians will always support our } \\
\text { political system if they are living in satisfied conditions in Malaysia. }\end{array}$ \\
\hline Interviewee 4 & $\begin{array}{l}\text { Each enterprise and political party has their owned experts to manage and arrange their } \\
\text { owned businesses and country respectively and independently. If they are well-manage } \\
\text { in their working fields, our economy and politic performance will be improved and } \\
\text { enhanced naturally. At the same time, civilians will satisfy and praise our political } \\
\text { system based on those mentioned well-perform economy and politic. }\end{array}$ \\
\hline Interviewee 5 & $\begin{array}{l}\text { Economy development is related to manpower development because economy } \\
\text { development requires civilian's knowledge and skills to gain profits for the country. In } \\
\text { Malaysia, we need civilian's knowledge and skills to develop our economy. If our } \\
\text { economy is staying in good condition, our political system will be more stabled due to no } \\
\text { unsatisfying in financial problems between government and civilians. }\end{array}$ \\
\hline Interviewee 7 & $\begin{array}{l}\text { Government always intend and concern on organizational manpower development and } \\
\text { economic development simultaneously to prove our country has a set of effective rules } \\
\text { to manage well in manpower development and economic development as a good image } \\
\text { globally. }\end{array}$ \\
\hline
\end{tabular}

Hypothesis 3: Economic development and growth are correlated to political stability based on national civilian perception.

“Table 3" The significant of economic development and its growth factor and political stability factor relationship in Malaysia.

\begin{tabular}{|c|c|}
\hline $\begin{array}{l}\text { Interviewed } \\
\text { Respondents }\end{array}$ & Reasonable Perceptions \\
\hline Interviewee 1 & $\begin{array}{l}\text { Capital resource is the vital role to consolidate political system in Malaysia. If our } \\
\text { fundamental economy is stabilized, national civilians will always initiatively to support } \\
\text { our political system. }\end{array}$ \\
\hline Interviewee 2 & $\begin{array}{l}\text { The first major action should be taken to stabilize local economy is the anti-corruption } \\
\text { issue. Our country should establish a political driving organization to observe and } \\
\text { surveillance each and everywhere departments which are related to economy industrials } \\
\text { for political system stabilization. }\end{array}$ \\
\hline Interviewee 3 & $\begin{array}{l}\text { While economy recession in Asia happened in 1997, Malaysia also affected during that } \\
\text { particular year. Commenced from } 1997 \text {, not all Malaysian fully been supporting our } \\
\text { political party until the election in } 2008 \text { was lost several seats. In fact, our economic } \\
\text { development directly influenced our political system. }\end{array}$ \\
\hline Interviewee 4 & $\begin{array}{l}\text { Currently, our government is not guiding our political system well enough especially } \\
\text { economic development. Majority civilians are not satisfied about low-income problem in } \\
\text { various business fields. In my viewpoint, majority civilians may not fully support } \\
\text { existing political system due to financial problem in their life. }\end{array}$ \\
\hline Interviewee 5 & $\begin{array}{l}\text { The status of economic development could change civilian's mindsets. Politicians are } \\
\text { difficult to lie on them because they could differentiate between worth financial } \\
\text { conditions and worse financial conditions in Malaysia. If our economic development is } \\
\text { consolidated enough, civilians still will vote current political party for next general } \\
\text { election to manage our country. }\end{array}$ \\
\hline Interviewee 7 & $\begin{array}{l}\text { Economic development and its growth is the source to improve civilian's lifestyle in } \\
\text { Malaysia. If their lifestyles are stayed in good conditions, they will not change our } \\
\text { current political system due to their satisfied lifestyle achieved by current governmental } \\
\text { management. }\end{array}$ \\
\hline $\begin{array}{l}\text { Interviewed } \\
\text { Respondents }\end{array}$ & Improvement Perceptions \\
\hline Interviewee 1 & $\begin{array}{l}\text { A fair economic policy is necessary to treat all enterprises fairy to improve existing } \\
\text { quality of products and services. Moreover, Economists should invest more funds in }\end{array}$ \\
\hline
\end{tabular}




\begin{tabular}{|l|l|}
\hline & $\begin{array}{l}\text { research and development. Research and development should be implemented by our } \\
\text { government sector to assist small and medium enterprises in Malaysia. Government } \\
\text { could provide extra subsidies and incentives for small and medium enterprises to } \\
\text { stimulate our economic development and indirectly the stimulation would consolidate } \\
\text { our political system. }\end{array}$ \\
\hline Interviewee 2 & $\begin{array}{l}\text { Current government also has to treat civilians fairly without racial discrimination. } \\
\text { National economy distribution should be administrated fairly for Malay, Chinese and } \\
\text { Indian races without boundaries. }\end{array}$ \\
\hline Interviewee 3 & $\begin{array}{l}\text { All civilians must cooperate together without racial discrimination to obey fully our } \\
\text { economical policies based on our political system. All civilians must work together too } \\
\text { to thrive our economy based on political policies that launched from politician's } \\
\text { strategies. }\end{array}$ \\
\hline Interviewee 4 & $\begin{array}{l}\text { Governmental revolution is the right time to stabilize our political system. Opponent } \\
\text { party has to give a chance to perform their ideologies in economy development for } \\
\text { civilians and let civilians to evaluate them according to their political performance. }\end{array}$ \\
\hline Interviewee 5 & $\begin{array}{l}\text { Both national politicians and civilians must be well-known investors to invest their funds } \\
\text { in right option. }\end{array}$ \\
\hline Interviewee 6 & $\begin{array}{l}\text { Government must provide various contributions for civilians in open-minded strategies } \\
\text { without racial-discrimination in Malaysia. }\end{array}$ \\
\hline Interviewee 7 & $\begin{array}{l}\text { Government can reduce current taxations especially vehicle tax and land tax. Those } \\
\text { particular taxations already provide burdens for civilians currently. Moreover, } \\
\text { government also can provide loans for civilians to open businesses freely in Malaysia. }\end{array}$ \\
\hline
\end{tabular}

Hypothesis 4: Governance is associated with economic development and growth based on national civilian perception.

"Table 4" The significant of economy development and growth factor, and governance factor relationship to stabilize political system in Malaysia.

\begin{tabular}{|c|c|}
\hline $\begin{array}{l}\text { Interviewed } \\
\text { Respondents }\end{array}$ & Reasonable Perceptions \\
\hline Interviewee 1 & $\begin{array}{l}\text { In Malaysia, our governance is matured to benefits civilians to move economy in correct } \\
\text { way. The mentioned benefits normally related to our economy development. }\end{array}$ \\
\hline Interviewee 2 & $\begin{array}{l}\text { National governance is relied on constitution that treated Malay race better than other } \\
\text { races including Chinese and Indian race. Our constitution is consisting Muslim priority } \\
\text { as prime benefits for Malay race. Government should concern on all races } \\
\text { simultaneously without discrimination however our governance gave prime benefit for } \\
\text { Malay race in Malaysia. }\end{array}$ \\
\hline Interviewee 3 & $\begin{array}{l}\text { National governance has priority to decide the fate of economic development in } \\
\text { Malaysia. Malay race priority has primary benefits in Malaysia indirectly influence other } \\
\text { races to develop national economy. }\end{array}$ \\
\hline Interviewee 4 & $\begin{array}{l}\text { Our economic policies are fully depended on national governance continually. The } \\
\text { implementation of economic development and its growth is based on our governance. If } \\
\text { our politicians are not obeyed governance, they may lead our economic development in } \\
\text { negative way to perform negative implication for civilians. }\end{array}$ \\
\hline Interviewee 6 & $\begin{array}{l}\text { We have to respect our governance because we are living in Malaysia. In fact, our } \\
\text { economic development must obey our governance. This is the way to prove patriotism in } \\
\text { Malaysia. }\end{array}$ \\
\hline
\end{tabular}

Hypothesis 5: Economic development and growth is correlated to control of inflation and leader based on national civilian perception

Hypothesis 6: Control of Inflation and Leader is correlated to political stability based on national civilian perception. 
"Table 5" The significant of economy development and its growth factor and political stability factor relationship are controlled by leader and control of inflation factor.

\begin{tabular}{|c|c|}
\hline $\begin{array}{c}\text { Interviewed } \\
\text { Respondents }\end{array}$ & Improvement Perceptions \\
\hline Interviewee 1 & $\begin{array}{l}\text { National politicians and economists are policy makers to influence our country } \\
\text { development. If national control of inflation is not controlled well, lower and middle } \\
\text { income civilians will ensure to change existing political system and its government. } \\
\text { Thus, a group of wise politicians and economists must focus and concern on any } \\
\text { governmental policies properly and strictly against inflation problem before launches to } \\
\text { society and civilians. }\end{array}$ \\
\hline Interviewee 2 & $\begin{array}{l}\text { In Malaysia, politician such as prime minister is an economist involving in financial } \\
\text { planning for the country. Currently, our politicians may not handle well economical } \\
\text { inflation problem in Malaysia. To improve existing economical inflation problem, we } \\
\text { need more capable economists in the future due to political system is relied on national } \\
\text { politicians and well control of inflation. Economy solution and planning always decide } \\
\text { by our prime minister to deal with economical inflation problem. }\end{array}$ \\
\hline Interviewee 3 & $\begin{array}{l}\text { Opponent parties should always observe all implementation of politician and economist. } \\
\text { In addition, control of inflation also should be observed by opponent parties too if they } \\
\text { found current political party provided prejudice ideologies against civilians and } \\
\text { economic development. }\end{array}$ \\
\hline Interviewee 4 & $\begin{array}{l}\text { Basically, our economic development is not managed well by current politicians, } \\
\text { economists and control of inflation strategies. Opponent political party may treat all } \\
\text { races fairly. Thus, the improvement may require governmental revolution by new } \\
\text { political party in the next election. To stabilize our political system, opponent party may } \\
\text { give a chance to lead our country. }\end{array}$ \\
\hline Interviewee 5 & $\begin{array}{l}\text { Both politicians and economists have to alert themselves involving in corruption as } \\
\text { major step to improve economic development in Malaysia. Politicians have to propose } \\
\text { pricing policies to control service and product prices in markets. Meanwhile, national } \\
\text { economists have to apply their knowledge to control inflation that affecting civilian's } \\
\text { lifestyle. If both politicians and economists are taken their responsibilities, civilians will } \\
\text { praise our current government and support it permanently. }\end{array}$ \\
\hline Interviewee 6 & $\begin{array}{l}\text { Different politicians, economist and control of inflation strategies are consisted various } \\
\text { solutions to confront economic problems in Malaysia. They can provide alternative } \\
\text { ideologies together to improve our political system. }\end{array}$ \\
\hline Interviewee 7 & $\begin{array}{l}\text { Both national politicians and economists are well-known in economic development. } \\
\text { They already improve national civilian's lifestyle by economic development after } 2020 \\
\text { vision has been launched until today. National leaders can teach civilians in political } \\
\text { knowledge through electronic media to let them understand our political issues and } \\
\text { political situation from time to time including political news. In addition, national leaders } \\
\text { can reduce and control product prices in markets to reduce civilian's financial burdens. }\end{array}$ \\
\hline
\end{tabular}

Hypothesis 7: Governance is correlated to political stability based on national civilian perception.

"Table 6" The significant of national governance factor and political stability factor relationship in Malaysia.

\begin{tabular}{|l|l|}
\hline $\begin{array}{l}\text { Interviewed } \\
\text { Respondents }\end{array}$ & \multicolumn{1}{c|}{ Reasonable Perceptions } \\
\hline Interviewee 1 & $\begin{array}{l}\text { National political stability depends on the factor of human potential obeying governance } \\
\text { to enforce and control governmental policies. If they are well controllers, national } \\
\text { stability of politic will be more stable. }\end{array}$ \\
\hline Interviewee 2 & $\begin{array}{l}\text { Malaysia governance is right for our civilians and we do not need to amend existing } \\
\text { governance that consisting constitution. The Malay and Islamic status are the fact to } \\
\text { manage our country formally. Political stability is relied on national governance directly } \\
\text { without any doubt in Malaysia. }\end{array}$ \\
\hline Interviewee 3 & $\begin{array}{l}\text { All civilians require transparent governance to let them truly understand it. A well- } \\
\text { structured political system must be understood by all national civilians. }\end{array}$ \\
\hline Interviewee 4 & $\begin{array}{l}\text { Each country has its owned governance. Malaysia also has its owned governance to lead } \\
\text { civilians. Our civilians require democratic system without racial-discrimination. }\end{array}$ \\
\hline Interviewee 5 & $\begin{array}{l}\text { Civilians are relied on right and appropriated governance in a country. In fact, Malaysia } \\
\text { is also confronting same situation. }\end{array}$ \\
\hline
\end{tabular}




\begin{tabular}{|c|c|}
\hline Interviewee 6 & $\begin{array}{l}\text { Governance has a set of administrative ways to lead civilians since established in } 1957 \text {. } \\
\text { The historical politicians already decided appropriated governance to treat all civilians in } \\
\text { Malaysia to sustain political system. }\end{array}$ \\
\hline Interviewee 7 & $\begin{array}{l}\text { Political stability is the way to prove capable leaders to manage well in a country. It also } \\
\text { proves local civilians are satisfied about their lifestyle in a country by the effectiveness } \\
\text { of governance. }\end{array}$ \\
\hline $\begin{array}{l}\text { Interviewed } \\
\text { Respondents }\end{array}$ & Improvement Perceptions \\
\hline Interviewee 1 & $\begin{array}{l}\text { Our politicians must listen civilian's voices sincerely and cater appropriate } \\
\text { implementation to solve their problems. In conversely, oppositional party is also played } \\
\text { an important role to defend civilian's interest if current controlling party is not managed } \\
\text { well political system for the civilians. }\end{array}$ \\
\hline Interviewee 2 & $\begin{array}{l}\text { All national civilians have priority to voice up against unfair governmental activities. To } \\
\text { stabilize political system, they have the right to voice up if they found unfair or } \\
\text { unsatisfied activities were launched from existing government. All civilians could protect } \\
\text { their properties and life through democratic system to against unfair governmental parties } \\
\text { in Malaysia. }\end{array}$ \\
\hline Interviewee 3 & $\begin{array}{l}\text { Political parties must implement all governmental plans based on democratic system } \\
\text { without racial - discrimination. Moreover, the government also has to treat all enterprises } \\
\text { fairly by democratic system. Our government hopefully do not just focus on Malay race } \\
\text { but ignoring other races especially Chinese race in economy development. }\end{array}$ \\
\hline Interviewee 4 & $\begin{array}{l}\text { To stabilize political system in Malaysia, governmental politicians have to treat all } \\
\text { civilians fairly without racial-discrimination. Any public facilities must be provided } \\
\text { regarding their race's requirement through fairness democratic system. }\end{array}$ \\
\hline Interviewee 5 & $\begin{array}{l}\text { All races must be tolerance and worked together without racial-discrimination though } \\
\text { actual democratic system. We need the real democratic system to solve political issues in } \\
\text { Malaysia. }\end{array}$ \\
\hline Interviewee 6 & $\begin{array}{l}\text { Both politicians and civilians have to obey national laws according to national } \\
\text { democratic system. This is the only way to stabilize our political system. }\end{array}$ \\
\hline Interviewee 7 & $\begin{array}{l}\text { Democratic system could allow government to organize political campaigns through } \\
\text { public speaking to let civilians understand current situation in Malaysia and prevent } \\
\text { misunderstanding between political implementation and civilian's requirement in } \\
\text { Malaysia. Government could organize live channel about public speaking for all civilians } \\
\text { about social problems, political problems and effective improvement and planning to } \\
\text { reduce misunderstanding about current political party. }\end{array}$ \\
\hline
\end{tabular}

Hypothesis 8: Governance is correlated to leader and control of corruption based o national civilian perception.

Hypothesis 9: Leader and control of corruption is correlated to political stability based on national civilian perception.

“Table 7" The significant of governance factor and political stability factor relationship are influenced and controlled by control of corruption and leader Factor.

\begin{tabular}{|c|l|}
\hline $\begin{array}{c}\text { Interviewed } \\
\text { Respondents }\end{array}$ & \multicolumn{1}{c|}{ Improvement Perceptions } \\
\hline Interviewee 1 & $\begin{array}{l}\text { When corruption is widely spreading in the whole country, a lot of funds would not be } \\
\text { utilized in proper way to develop and improve existing society and civilian's lifestyle. } \\
\text { Our politicians should be self-managed peoples to provide efficiency, trustworthy and } \\
\text { free of corruption to obey fully our governance for existing politic. }\end{array}$ \\
\hline Interviewee 2 & $\begin{array}{l}\text { To stabilize our political system, our government should offer opened tenders for all } \\
\text { national companies without corruption interference. Currently, our governance always } \\
\text { offers tenders for certain companies who have been established good relationship } \\
\text { between politicians and companies at top-management. Those particular companies } \\
\text { might utilize corruption way for the politicians during tender agreement. To solve the } \\
\text { problem, our politicians have to obey our governance fully to make a transparency } \\
\text { policies regarding tender arrangement. }\end{array}$ \\
\hline Interviewee 3 & $\begin{array}{l}\text { All, national politicians must be self- discipline persons because the effectiveness of } \\
\text { corruption control is based on self - discipline politicians to manage it. At the same time, } \\
\text { self - discipline politicians would like to prevent corruption fully to improve our political }\end{array}$ \\
\hline
\end{tabular}




\begin{tabular}{|l|l|}
\hline & system. \\
\hline Interviewee 4 & $\begin{array}{l}\text { National politic system requires governance strictly and fairly against both political } \\
\text { corruption and civilian's corruption. We need honor politicians to obey governance } \\
\text { against corruption without racial-discrimination and political status. Our politicians have } \\
\text { to amend governance to treat corruption strictly and fairness justice for all civilians and } \\
\text { politicians. }\end{array}$ \\
\hline Interviewee 5 & $\begin{array}{l}\text { Government and politicians must well-known and sensitive through civilian's perception. } \\
\text { Both government and politicians have to amend governance by civilian's perception } \\
\text { from time to time which is appropriated for that trend. In addition, fairness and justice } \\
\text { elements are necessary under control of corruption. To stabilize our political system, } \\
\text { government and politicians have to treat control of corruption strictly. }\end{array}$ \\
\hline Interviewee 6 & $\begin{array}{l}\text { National politicians and civilians have to restraint their attitude involving in corruption. } \\
\text { In addition, they also need to support our anti - corruption agency to reduce corruption } \\
\text { spreading in whole Malaysia. }\end{array}$ \\
\hline Interviewee 7 & $\begin{array}{l}\text { Anti-corruption commission was established to arrest people in corruption. Our top } \\
\text { national politicians must strictly instruct national Anti-Corruption Commission to arrest } \\
\text { any suspects in political corruption. It can reduce losing national funds for civilian's } \\
\text { facilities. }\end{array}$ \\
\hline
\end{tabular}

Hypothesis 10: Political culture is associated with political stability based on national civilian perception.

"Table 8" The significant of political culture factor and political stability factor relationship in Malaysia.

\begin{tabular}{|c|c|}
\hline $\begin{array}{l}\text { Interviewed } \\
\text { Respondents }\end{array}$ & Reasonable Perceptions \\
\hline Interviewee 1 & $\begin{array}{l}\text { Our country is consisting multi-culture politicians to administrate our political system. } \\
\text { Different cultural politicians have their owned cultural mindset to foster various political } \\
\text { cultures according to their races in Malaysia. Thus, those politicians have their owned } \\
\text { ways and opinions to manage and influence our political system. }\end{array}$ \\
\hline Interviewee 2 & $\begin{array}{l}\text { All countries are consisting political cultures influenced by its constitutions. Our country, } \\
\text { Malaysia also has its own political culture after independent. Majority political parties } \\
\text { against each other parties to gain victory of election. Each member of internal party } \\
\text { might affect its dignity of party if any one of the members voice up negative opinions via } \\
\text { civilians. Thus, opponent parties would attack them mentally to protect the properties of } \\
\text { civilian. }\end{array}$ \\
\hline Interviewee 3 & $\begin{array}{l}\text { No matter a political culture either in positive way or negative way, the status of political } \\
\text { system also would be influenced either positive implication or negative implication. It } \\
\text { depends on politicians either self - positive attitude manners or self - negative attitude } \\
\text { manners to manage our political system. }\end{array}$ \\
\hline Interviewee 4 & $\begin{array}{l}\text { Political corruption and racial-discrimination issues are major elements in our political } \\
\text { culture. Obviously, civilians are not fully supported our political system due to } \\
\text { mentioned negative implication of political culture. }\end{array}$ \\
\hline Interviewee 5 & $\begin{array}{l}\text { All political implementation for civilians depend on civilian's reaction either positive or } \\
\text { negative implication. Civilians are able to evaluate political culture by that particular } \\
\text { implication in Malaysia and directly influence our political system for next general } \\
\text { election. }\end{array}$ \\
\hline Interviewee 6 & $\begin{array}{l}\text { Our political culture basically retained since } 1957 \text { until now without any obviously } \\
\text { changes. Our political system retained the same situation depending on our political } \\
\text { cultures. }\end{array}$ \\
\hline Interviewee 7 & $\begin{array}{l}\text { Current political culture always threatens races through public speaking especially racial- } \\
\text { conflict issues in Malaysia. It might lose seats in general election to influence current } \\
\text { political system in negative way. }\end{array}$ \\
\hline
\end{tabular}

Hypothesis 11: Governance is associated with political culture based on national civilian perception. 
"Table 9" The significant of governance factor and political culture factor relationship to stabilize political system in Malaysia.

\begin{tabular}{|c|c|}
\hline $\begin{array}{l}\text { Interviewed } \\
\text { Respondents }\end{array}$ & Reasonable Perceptions \\
\hline Interviewee 2 & $\begin{array}{l}\text { Lord Reid was attempted to illustrate a skeleton of constitution for Malaysian including } \\
\text { three major races such as Malay, Chinese and Indian races before independent in } 1957 . \\
\text { He created a set of constitutions what he believed was suitable for all Malaysian during } \\
\text { his living period. Intuitively, political culture was born in that time until now however } \\
\text { we have been passed through for } 56 \text { years since Independence Day in } 1957 \text {. Of course, } \\
\text { stabilized political system in Malaysia depends on existing political cultures due to } \\
\text { historical facts were influenced our political culture since } 1957 \text {. On the other hands, the } \\
\text { ideology of opponent parties sometimes provides alternate opinions against } \\
\text { constitutional governance while they seeking limitation of our constitution may affect the } \\
\text { human right of civilian. The purpose of opponent parties are tried to amend our } \\
\text { constitution to confuse civilians. Those mentioned attitudes were existed as political } \\
\text { culture in Malaysia since } 1957 \text {. }\end{array}$ \\
\hline Interviewee 3 & $\begin{array}{l}\text { National governance has been established since1957; it has been concerned more on } \\
\text { Malay races regarding their interests and status in Malaysia. Therefore, other race's } \\
\text { status especially Chinese and Indian races were not compared with Malay race in } \\
\text { Malaysia. In fact, our political culture consisting unfair issues for each discussion in } \\
\text { Parliament. To solve race's issues in Malaysia, all politicians have to treat and assist } \\
\text { civilians based on their races requirement. }\end{array}$ \\
\hline Interviewee 4 & $\begin{array}{l}\text { The source of political culture was established since } 1957 \text { from structural governance. } \\
\text { All different racial politicians have been working together so many years in the same } \\
\text { political culture to manage our political system. This situation will go on continually } \\
\text { from one generation to next generation. }\end{array}$ \\
\hline Interviewee 5 & $\begin{array}{l}\text { Harmonic political culture requires ethical politicians as well as national governance is } \\
\text { fairness to treat all civilians. Obviously, both national governance and political culture } \\
\text { are related to stabilize our political system while civilians are supporting it regarding to } \\
\text { harmonic political culture. }\end{array}$ \\
\hline Interviewee 6 & $\begin{array}{l}\text { Governance is the source to lead politicians directly. Obviously, politicians could build } \\
\text { and retain political culture while obeying our governance. }\end{array}$ \\
\hline $\begin{array}{l}\text { Interviewed } \\
\text { Respondents }\end{array}$ & Improvement Perceptions \\
\hline Interviewee 2 & $\begin{array}{l}\text { All political parties may provide their own ideology for the country without sensitive } \\
\text { issues especially about Muslim priority in Malaysia. Those parties have their right to } \\
\text { fight for victory of election in the boundary of harmony. Aggressive action should be } \\
\text { prevented as well as possible through cooperation between various political parties. All } \\
\text { parties should concern on sensitive issues rationally to prevent racial - tension happening } \\
\text { in Malaysia because our status of political system can be varied without racial - tension } \\
\text { prevention and attention }\end{array}$ \\
\hline Interviewee 3 & $\begin{array}{l}\text { All politicians have to be neutral to work and discuss together without racial- } \\
\text { discrimination. Moreover, our politicians also have to discuss together to protect } \\
\text { civilian's life and interests fairly. }\end{array}$ \\
\hline Interviewee 4 & $\begin{array}{l}\text { Tolerance issues between all races are the first step to be improved in our political } \\
\text { culture. Due to our political system requires no racial-discrimination between politicians, } \\
\text { all different race of politicians have to tolerance each other to manage our political } \\
\text { system in stable line. }\end{array}$ \\
\hline Interviewee 5 & $\begin{array}{l}\text { Government has to reduce political corruption as a good image for civilians. Moreover, } \\
\text { government and political parties should not over utilize priority through civilians. Both } \\
\text { statements would establish harmonic political culture and provide good image to let } \\
\text { civilians support our political system. }\end{array}$ \\
\hline Interviewee 6 & $\begin{array}{l}\text { Our political system is stable currently. Current political culture is appropriated and right } \\
\text { to influence our political system. }\end{array}$ \\
\hline Interviewee 7 & $\begin{array}{l}\text { Our political cultures can be improved if all politicians are willing to help each other's } \\
\text { between political parties. All political parties must focus on local civilian's problems as } \\
\text { priorities but not winning for general election. }\end{array}$ \\
\hline
\end{tabular}


"Table 10" The significant of technological development factor and political stability factor relationship in Malaysia.

\begin{tabular}{|c|c|}
\hline $\begin{array}{l}\text { Interviewed } \\
\text { Respondents }\end{array}$ & Reasonable Perceptions \\
\hline Interviewee 2 & $\begin{array}{l}\text { Technology development can influence political system stability in Malaysia due to all } \\
\text { current issues easily spread widely by various technological media for all civilians. They } \\
\text { may evaluate current government administration based on internet news and live } \\
\text { channels on Television. Mainstream media normally present current issues about positive } \\
\text { impact on government side. It shows all about positive actions and results to convince } \\
\text { civilians and let them always support current political party. Civilians may provide } \\
\text { positive evaluation for the government. Indirectly, the status of Malaysia political system } \\
\text { may preserve longer in the future. }\end{array}$ \\
\hline Interviewee 3 & $\begin{array}{l}\text { Technology development could offer more job vacancies for civilians. In fact, } \\
\text { technology development naturally enhances our political system while majority civilians } \\
\text { have their own satisfied careers in Malaysia. }\end{array}$ \\
\hline Interviewee 4 & $\begin{array}{l}\text { Yes of cause. Without technology development, political party is difficult to spread } \\
\text { political issues, activities and implications for civilians. Those civilians, are not fully } \\
\text { received political information from political party and government without technology } \\
\text { development. }\end{array}$ \\
\hline Interviewee 5 & $\begin{array}{l}\text { Internet technology could easily spread political issues for everyone and getting } \\
\text { responses instantly. Civilians could utilize current technologies to evaluate our political } \\
\text { system instantly. }\end{array}$ \\
\hline Interviewee 6 & $\begin{array}{l}\text { Technology development could provide convenience and fast way to spread political } \\
\text { issues for civilians. So, they could get instant information to evaluate our political party } \\
\text { and government. }\end{array}$ \\
\hline Interviewee 7 & $\begin{array}{l}\text { Our government and enterprises were proposed and provided various technologies in the } \\
\text { markets. Many civilians utilized current technologies as a trend in Malaysia. Without the } \\
\text { technology development, civilians will not support current political system because } \\
\text { civilians have been utilized it as a culture in Malaysia. }\end{array}$ \\
\hline $\begin{array}{l}\text { Interviewed } \\
\text { Respondents }\end{array}$ & Improvement Perceptions \\
\hline Interviewee 2 & $\begin{array}{l}\text { To improve current political system, latest technology has to be applied from time to } \\
\text { time where all current issues can be spread faster and widely to all civilians and let them } \\
\text { know what is happening in our country. It may convince civilians as fast as possible base } \\
\text { on latest technology. }\end{array}$ \\
\hline Interviewee 3 & $\begin{array}{l}\text { We have to improve current technologies through innovative ideologies due to } \\
\text { innovative ideologies always attract foreign investors willing to invest their funds in } \\
\text { innovative technologies. Thus, we can utilize the foreign funds to develop those } \\
\text { innovative technologies in smoothly stream. Latest technologies can spread our political } \\
\text { issues for all civilians widely and faster by various electronic media. They can evaluate } \\
\text { our government by those innovative technologies. }\end{array}$ \\
\hline Interviewee 4 & $\begin{array}{l}\text { We can utilize latest technologies no matter those technologies either from local or } \\
\text { import from foreign countries to develop our economy to improve civilian's lifestyle. If } \\
\text { our civilians are living in a good economical environment, they still would support our } \\
\text { political system without any changes. }\end{array}$ \\
\hline Interviewee 5 & $\begin{array}{l}\text { Freely utilization is the key point to apply technologies by civilians. They could evaluate } \\
\text { political party's performances freely regarding to technology applications. }\end{array}$ \\
\hline Interviewee 6 & $\begin{array}{l}\text { Civilians can freely provide their innovative ideas for governmental sector to develop } \\
\text { technology for our country. }\end{array}$ \\
\hline Interviewee 7 & $\begin{array}{l}\text { Government can introduce various information technology courses for civilians to learn } \\
\text { about it and let them following information technology trend globally. Civilians can } \\
\text { obtain information technology skills to develop national technologies to improve our } \\
\text { political system. }\end{array}$ \\
\hline
\end{tabular}

Hypothesis 13: Technology development is associated with invention and innovation based on national civilian perception.

Hypothesis 14: Invention and innovation is associated with political stability based on national civilian perception. 
"Table 11" The significant of technology development factor and political stability factor relationship are controlled and influenced by new invention and innovation factor in Malaysia.

\begin{tabular}{|c|c|}
\hline $\begin{array}{l}\text { Interviewed } \\
\text { Respondents }\end{array}$ & Improvement Perceptions \\
\hline Interviewee 2 & $\begin{array}{l}\text { Latest technologies always replace current technologies rapidly because the improvement } \\
\text { of the facility could attract civilians apply new technologies. Nowadays, our country is } \\
\text { using and applying wireless technology to provide more conveniences to know about our } \\
\text { political system. Last time, we had to use limited wired technology to access internet but } \\
\text { now we can access internet via wireless technology. Civilians could simply view and } \\
\text { search various current issues through internet without boundary. Many civilians could } \\
\text { evaluate our governmental performance either support current party or against it base on } \\
\text { fastest technology. }\end{array}$ \\
\hline Interviewee 3 & $\begin{array}{l}\text { Technological invention and innovation is the factor to propose marketing strategy in } \\
\text { Malaysia. The marketing strategy directly attracts civilians replace used technologies. } \\
\text { The velocity to spread political issues always in improvement situation while marketing } \\
\text { strategy is fully implemented for all civilians. Civilians can receive political issues in } \\
\text { faster and easy way to understand current political situation. In fact, civilians can } \\
\text { evaluate our political system as fast as possible by the new inventive and innovative } \\
\text { technologies. }\end{array}$ \\
\hline Interviewee 4 & $\begin{array}{l}\text { Local civilians can utilize their knowledge and ideas to invent and innovate new } \\
\text { technologies. They may also attempt to develop new technologies in political fields. } \\
\text { Local politicians can apply the new technologies to spread any political issues and } \\
\text { activities in faster ways. }\end{array}$ \\
\hline Interviewee 5 & $\begin{array}{l}\text { Government can provide good remuneration for information technology experts and } \\
\text { engineers to restraint them working in other countries. We need their knowledge and } \\
\text { innovative ideologies to develop national technologies. }\end{array}$ \\
\hline Interviewee 6 & $\begin{array}{l}\text { Government can foster many experts in technological industry and also absorb latest } \\
\text { invented and innovated information from foreign countries to innovate new technologies } \\
\text { in our country. }\end{array}$ \\
\hline Interviewee 7 & $\begin{array}{l}\text { Experts under information technology can invent and innovate new technologies and } \\
\text { propose the new technologies in governmental sector. Our governmental sector can } \\
\text { launch the latest invention and innovation in technological markets for all civilians. } \\
\text { Hence, civilians have a chance to apply latest technologies to improve current } \\
\text { technologies as a trend to enhance the image of technology development in Malaysia. }\end{array}$ \\
\hline
\end{tabular}

Hypothesis 15: Security environment is associated with political stability based on national civilian perception.

"Table 12" The significant of security environment factor and political stability factor relationship in Malaysia.

\begin{tabular}{|l|l|}
\hline $\begin{array}{l}\text { Interviewed } \\
\text { Respondents }\end{array}$ & \multicolumn{1}{|c|}{ Reasonable Perceptions } \\
\hline Interviewee 2 & $\begin{array}{l}\text { The relationship among political parties may be enhanced if all parties are really caring } \\
\text { about civilians without racial discrimination. All civilians may live in secured } \\
\text { environment if all political parties always provide positive opinions and ideas to improve } \\
\text { civilian's lifestyle without discrimination. }\end{array}$ \\
\hline Interviewee 3 & $\begin{array}{l}\text { Civil chaos may be happened without a security environment for civilians. Civil chaos } \\
\text { may influence our political system directly. The first criteria to live in a country are a } \\
\text { safety environment for civilians. }\end{array}$ \\
\hline Interviewee 4 & $\begin{array}{l}\text { In Malaysia, criminal issues always occur via civilians directly. Our government always } \\
\text { cater various security system physically and virtually to protect civilians. In addition, } \\
\text { government also increases additional security systems to reduce crime activities as less } \\
\text { as possible. That security implementation already decided the fate of sustainability of } \\
\text { political system in the future because civilians still would support current political party } \\
\text { once their life had protected. }\end{array}$ \\
\hline Interviewee 5 & $\begin{array}{l}\text { A good conditional security environment can reduce victims appearing in a country. } \\
\text { Each civilian would support a peaceful political system in a country. }\end{array}$ \\
\hline Interviewee 6 & Security environment contains armed force, security force and police force to protect \\
\hline
\end{tabular}




\begin{tabular}{|c|c|}
\hline & civilians in a country. \\
\hline Interviewee 7 & $\begin{array}{l}\text { A save and peaceful environment allows political campaigns execute safely in Malaysia. } \\
\text { Thus, safety environment is the basic requirement for civilians to live in Malaysia. They } \\
\text { always support a political party that focusing safely environment as first consideration. }\end{array}$ \\
\hline $\begin{array}{l}\text { Interviewed } \\
\text { Respondents }\end{array}$ & Improvement Perceptions \\
\hline Interviewee 2 & $\begin{array}{l}\text { National government should not restrict any media to offer latest news for civilians. They } \\
\text { should treat media in neutral way without prejudice. So, all media can offer true issues } \\
\text { and news for civilians and let them evaluate current performance of government. } \\
\text { Civilians can either critic or praise our government through internet service without } \\
\text { aggressive activities especially physical protestation. At the same time, government also } \\
\text { should listen up civilian's voice and improve society until they still support current } \\
\text { government and the political system. }\end{array}$ \\
\hline Interviewee 3 & $\begin{array}{l}\text { To consolidate our security environment, we have to implement democratic system } \\
\text { seriously. All civilians have their priorities to voice up their suffering issues through } \\
\text { political parties. Each political party must protect and assist their races based on the } \\
\text { suffering issues. If each political party is really can provide solutions for the suffering } \\
\text { issues, our civilians will support existing political system in the future. }\end{array}$ \\
\hline Interviewee 4 & $\begin{array}{l}\text { Government shall concern on public security on civilian's living areas. That public } \\
\text { security must be arranged without racial-discrimination. If our government really can } \\
\text { protect civilian's life, they still will support current political party and the system too. }\end{array}$ \\
\hline Interviewee 5 & $\begin{array}{l}\text { Government shall increase human capital in armed forces. Government also needs to } \\
\text { enhance anti-corruption policies and strategies to prevent corruption in politics. In } \\
\text { addition, government servants must change their working attitudes in positive way. }\end{array}$ \\
\hline Interviewee 6 & $\begin{array}{l}\text { Government can utilize technological security system to enhance security environment in } \\
\text { civilian's living areas. In addition, government also has to recruit more civilians in armed } \\
\text { force and police force to protect our country. }\end{array}$ \\
\hline Interviewee 7 & $\begin{array}{l}\text { Government can recruit more civilians involve in armed force. Our government also can } \\
\text { offer extra remuneration for volunteers under reserve armed force. }\end{array}$ \\
\hline
\end{tabular}

Hypothesis 16: Security environment is associated with civilian support based on national civilian perception.

Hypothesis 17: Civilian support is associated with political stability based on national civilian perception.

“Table 13" The significant of security environment factor and political stability factor relationship are controlled and influenced by civilian support factor.

\begin{tabular}{|l|l|}
\hline $\begin{array}{l}\text { Interviewed } \\
\text { Respondents }\end{array}$ & $\begin{array}{l}\text { Improvement Perceptions } \\
\text { Interviewee 2 }\end{array}$ \\
$\begin{array}{l}\text { National civilian alliance should be organized without concerning political background, } \\
\text { without racial discrimination. In addition, the relationship between police enforcements } \\
\text { and civilians should be established through governmental planning and execution. }\end{array}$ \\
\hline Interviewee 3 & $\begin{array}{l}\text { Government can propose various public protections for civilians regarding to their race's } \\
\text { requirement. Each political party has to observe civilians to understand what the really } \\
\text { problem happening in the society. Each political party can propose various solutions } \\
\text { regarding to security issues. Once civilian's life and properties were secured, they would } \\
\text { support current political system without any doubts because each civilian requires a } \\
\text { secured environment to protect his or her family and life. }\end{array}$ \\
\hline Interviewee 4 & $\begin{array}{l}\text { Government can propose more security systems on civilian's living areas and local } \\
\text { societies to protect their life. Malaysians are threatened by various criminal activities } \\
\text { everywhere. So, local civilians request government provides more security forces on } \\
\text { their living places and societies to reduce crime activities in Malaysia. If majority } \\
\text { civilian's life is protected, they surely satisfy our political system while their life and } \\
\text { families are staying on safe zone. }\end{array}$ \\
\hline Interviewee 5 & $\begin{array}{l}\text { All civilians must have patriotism mindsets to respect our country. They also are willing } \\
\text { to be volunteers in armed forces to protect country. Moreover, both civilians and police } \\
\text { forces should be cooperated together to cultivate a peace environment in Malaysia. }\end{array}$ \\
\hline
\end{tabular}




\begin{tabular}{|l|l|}
\hline Interviewee 6 & $\begin{array}{l}\text { In Malaysia, many civilians involving in armed forces and police force as volunteers. } \\
\text { They are supportive peoples in current political party and government because their } \\
\text { incomes from government. Thus, our government can purpose more remuneration in } \\
\text { armed force and police force to attract more civilians joins with our armed forces and } \\
\text { police force. }\end{array}$ \\
\hline Interviewee 7 & $\begin{array}{l}\text { Government sector can instruct security forces in political campaigns to prevent civil } \\
\text { chaos happening in Malaysia. The civil chaos will destruct political system. Thus, } \\
\text { government has to protect our civilians injuring in general election and political } \\
\text { campaigns because we still need them to support our political system from time to time } \\
\text { depending on improvement of civilian's problems in the future. }\end{array}$ \\
\hline
\end{tabular}

Hypothesis 18: Social development is correlated to political stability based on national civilian perception.

"Table 14" The significant of social development and political stability factor relationship in Malaysia

\begin{tabular}{|c|c|}
\hline $\begin{array}{l}\text { Interviewed } \\
\text { Respondents }\end{array}$ & Reasonable Perceptions \\
\hline Interviewee 2 & $\begin{array}{l}\text { Civilians always request fundamental requirements such as educational scholarship or sponsorship, } \\
\text { personal insurance, financial loan and others from government to improve their lifestyle. They are } \\
\text { not willing to live in suffering country without governmental assistance. If their fundamental } \\
\text { requirements are satisfied from governmental assistance, they still may continue support existing } \\
\text { government and its political system. }\end{array}$ \\
\hline Interviewee 3 & $\begin{array}{l}\text { Due to our government has been catered a lot public facilities such as primary and secondary } \\
\text { school establishment, public highway establishment and train lane establishment in Malaysia, } \\
\text { national civilians could live in a proceeding country based on the mentioned effective social } \\
\text { development. In fact, civilians are surely to support current government and political system. }\end{array}$ \\
\hline Interviewee 4 & $\begin{array}{l}\text { Majority civilians are low-income in Malaysia. They need assistance especially financial problems } \\
\text { in societies from our government. If our government proposes various public facilities for the } \\
\text { societies, civilians surely praise and support our existing government. }\end{array}$ \\
\hline Interviewee 5 & $\begin{array}{l}\text { Public facility provision is the key point to reduce unsatisfying issues between races in Malaysia. } \\
\text { Our civilians would support our political party if they develop the societies without racial- } \\
\text { discrimination issue. }\end{array}$ \\
\hline Interviewee 7 & $\begin{array}{l}\text { Governmental social developments attempted to control and restrict western cultures influencing } \\
\text { national civilians. Current political party has been proposed various traditional cultures to } \\
\text { influence our civilians in the societies and changed their mindsets in ethical issues. Government } \\
\text { already implemented various social developments to mature civilian's mindsets. We need our } \\
\text { civilians respect and obey our constitutions and national governance to preserve political stability } \\
\text { in long term planning. }\end{array}$ \\
\hline $\begin{array}{l}\text { Interviewed } \\
\text { Respondents }\end{array}$ & Improvement Perceptions \\
\hline Interviewee 2 & $\begin{array}{l}\text { Government has to use national funds wisely to help civilians. They must arrange and manage } \\
\text { national funds properly to avoid corruption. National funds can be used in social development } \\
\text { smoothly without corruption interference. On the other hands, government can consolidate MACC } \\
\text { (Malaysian Anti-Corruption Commission) to avoid corruption happen on civilians as victims. }\end{array}$ \\
\hline Interviewee 3 & $\begin{array}{l}\text { A stabilized political system requires diplomatic strategies. In Malaysia, our government can } \\
\text { propose various diplomatic strategies to attract and negotiate foreign investors attempting invest } \\
\text { their funds in our country. Thus, national politicians can utilize those funds to develop our national } \\
\text { society. A proceeding society will always encourage civilians support current political system } \\
\text { because civilians can live in a facilitated environment which catered by existing government. }\end{array}$ \\
\hline Interviewee 4 & $\begin{array}{l}\text { Current political party is not well-performed in social development. Civilians request opponent } \\
\text { party replaces existing political party. They hope opponent party will manage our societies better } \\
\text { than current political party. }\end{array}$ \\
\hline Interviewee 5 & $\begin{array}{l}\text { First step, political conflict should be prevented between races. Government and civilians must } \\
\text { always cooperate to decide suitable social development to avoid unnecessary implementation. It } \\
\text { will save a lot of financial expenditures for the country. }\end{array}$ \\
\hline Interviewee 6 & $\begin{array}{l}\text { Government can renew and replace public facilities from time to time to reduce civilian's } \\
\text { complaints through our government and political party. }\end{array}$ \\
\hline Interviewee 7 & $\begin{array}{l}\text { Government, political party and enterprises are required to provide political lessons under social } \\
\text { development for civilians in various ways including electronic media and educational policies. }\end{array}$ \\
\hline
\end{tabular}

Hypothesis 19: Social development is associated with governance based on national civilian perception. 
"Table 15" The significant of governance factor and social development factor relationship to stabilize political system in Malaysia.

\begin{tabular}{|c|c|}
\hline $\begin{array}{l}\text { Interviewed } \\
\text { Respondents }\end{array}$ & Reasonable Perceptions \\
\hline Interviewee 2 & $\begin{array}{l}\text { Before the year 1969, NEP or called New Economy Policy had not existed yet in } \\
\text { Malaysia. Racial properties did not arrange properly during that period. Consequently, } \\
\text { unfair racial properties arrangement appeared a big gap between Malay race and Chinese } \\
\text { race. After the year 1969, NEP was launched by our second prime minister, Tun Abdul } \\
\text { Razak who attempted to solve problem of unfair racial properties arrangement } \\
\text { successfully until now. }\end{array}$ \\
\hline Interviewee 3 & $\begin{array}{l}\text { The relationship between governance and social development are concerned on fair } \\
\text { treatment for all civilians including Malay, Chinese and Indian races. However, our } \\
\text { governance is focusing on major Malay prime priority; government also has take care } \\
\text { other races because they are living in Malaysia too. If our government more concern on } \\
\text { social development for Malay race by our governance accordingly, other races may not } \\
\text { satisfy for less current social development in Malaysia. }\end{array}$ \\
\hline Interviewee 4 & $\begin{array}{l}\text { The policies of social development are relied on governance. National governance } \\
\text { should contain a set of laws to declare policies of social development in a fairness way } \\
\text { for all civilians consistently. Thus, local social development would be implemented } \\
\text { fairly by politicians for all civilians. Our civilians could receive governmental benefits } \\
\text { without racial-discrimination based on fairness policies of social development. Local } \\
\text { civilians would still support our political system while government providing fairly } \\
\text { benefits for all civilians in social development. }\end{array}$ \\
\hline Interviewee 5 & $\begin{array}{l}\text { Unfair governance would establish prejudice social development in Malaysia. Thus, } \\
\text { national governance must give a right direction to let politicians implement social } \\
\text { development without negative implication for civilians. }\end{array}$ \\
\hline Interviewee 6 & $\begin{array}{l}\text { Civilians always deal with government regarding public deficiency in social } \\
\text { development. Government have to obey our governance to develop public facilitates in } \\
\text { the societies. Although civilians propose various opinions in social development, } \\
\text { government also has to evaluate those ideas either obeying our governance or vice-versa. }\end{array}$ \\
\hline Interviewee 7 & $\begin{array}{l}\text { The collaboration between local races is one of the laws under our governance. Thus, } \\
\text { government has to develop our societies without racial discrimination. In addition, } \\
\text { government also needs to take responsibilities in social development regarding to racial- } \\
\text { conflicts in social development due to national governance consisting declared } \\
\text { distribution for all races in Malaysia. }\end{array}$ \\
\hline
\end{tabular}

\section{Discussions \& Recommendations}

The organizational manpower development factor is totally related to our political system in Malaysia. Enterprises, government and political parties have to train and foster a group of skilful and full-knowledge experts in related working fields to admin and manage businesses and political system respectively in efficient ways. Government could offer various training programs for civilians, politicians, governmental staffs and businessman fairly for them to enhance our manpower development. The positive implication for national civilians can be implemented if a country always concerned on organizational manpower development in both business industry and political industry. In economic industry, manpower development is mandatory to foster skilful and knowledgeable experts to manage well our national economy. Once our economic development and its growth improved, naturally national civilians would satisfy our economic development and still support our existing political system sincerely. At the same time, politicians also require manpower development to enhance their abilities in political skills to fight against each political party during general election. Obviously, no matter who is involving either economic field or political field, senior management always trains and conveys their experiences and knowledge for junior management continually for long term stability in political system.

National economic development and its growth factor are correlated directly to our political system due to civilians caring about their personal finance problems for their lifestyle in a country. To satisfy a political system, governmental policies for economic issues have to be fairly treated all civilians without racialdiscrimination for all races in Malaysia. Government and national politicians could offer various economic assistances to help enterprises and low-income civilians for growing national economic development. Moreover, government and the politicians also could control market prices and the quality of product to reduce civilian's burdens in economic problems. Civilians willing to support existing political system based on fairness treatment in economic development between races in a country. In addition, government and related politicians have to strengthen our capital resource because it is the foundation of stabilized economy for a country. The capital 
resource has to be utilized wisely from government and politicians without corruption issues occurring in Malaysia. They must be anti-corruption defenders to utilize our capital resource in economy for all races fairly in Malaysia. At the same time, certain civilians also not satisfied our political system, they requested opponent party involving in current political system especially economic development because they worry about governmental corruption. Current civilians could understand political issues and economic issues in our country because they could alert our environmental development based on governmental implementation especially negative voice up through civilians concerning certain impacts in our societies.

To success national economy, a country requires national civilians, governments and politicians obeying national governance. Each country has a set of laws under governance to restraint freedom of economic development. In Malaysia, we need certain laws under governance against illegal implementation in economic development. Moreover, fairness of governance also needed for Malaysian without racial-discrimination because civilians need fairness of governances to restraint both politicians, and civilians involving in economic development for our political system in stable line. Civilians would satisfy our political system and support it by fairness of governance to treat all people in economic development. In addition, all civilians must obey governance to perform patriotism for a country and a good image to respect our country in economic development by the rules of governance.

The positive relationship between economic development and political stability require the capable leaders and control of inflation. In fact, politicians and economists are policy makers to decide both economic development and existing political system. If they are incapable to lead our economy, economy recession will be happened to lead civilians willing to change current political system. Some of the civilians are not accepted our political system due to incapable politicians and economists leading our country. They request opponent part always observe current political party and government regarding economic development and its growth as well as observing inflation control in stable line. To overcome economic problems, politicians and economists have to be cooperated without racial-discrimination to provide alternative solutions to help our economy and civilians in Malaysia. In addition, politicians and economists also need to treat economic development without corruption due to corruption would destruct our economy and leading civilians in a suffering way.

To foster a stable country via political system, the force of human factor to obey national governance is the source to stabilize political system. In Malaysia, we need governmental policies but have to follow our rules of governance to manage our country. Government and politicians must propose transparent governance to let all civilians understated about it to avoid conflict between races happening in the future. All civilians have to respect our governance because it has been accomplished since our independence day in 1957. In Malaysia, we do not follow democratic system fully. Thus, civilians are hoping to voice up their problems for current political party and making changes in a better administrative way for our country. They are also hoping opponent party always defends civilian's interests while civilian's interests are threatening by governmental implementation in negative ways. Consequently, civilians just hope government under fairness management to assist and help civilians without racial-discrimination.

A group of capable leaders and well-controlled of corruption could influence both political stability factor and governance factor. Corruption directly influences national funds losing to threat civilian's lifestyle. They totally not support our political system in a corrupted country. To avoid it, all national politicians must be self-discipline against corruption however we already had anti-corruption commission. Moreover, our governance did not have any laws to support corruption through democratic system in politic. Therefore, politicians have to strictly obey our governance against corruption sincerely to foster a stabilized country without corruption as a vision as well as those politicians performs capabilities while corruption is under controlled.

Multi-races in politic to manage our country is our political culture. To stabilized our political system, we are consisting Malay, Chinese and Indian races in politic to convey and provide their opinions and solutions under civilian's problems in societies. Thus, they have to corporate together to avoid racial conflicts happening in politic and affecting civilian's mindsets regarding to racial-discrimination issues. In addition, political corruption also considers a culture in national politics. Majority civilians are suspecting national politicians are involving in corruption. Therefore, politicians have to alert about it because it could influence our political system in negative image for civilians.

Three major races living in Malaysia are Malay, Chinese and Indian. Since national independent in 1957, our governance has been controlled by a set of constitutions. The political culture also has been fostered since 1957 until today. So, racial interest's distribution was decided between Malay, Chinese and Indian races in Malaysia bases on our governance. To improve this situation, current politicians have to alert sensitive issues especially historical racial problems to avoid and prevent racial conflict in Malaysia. Therefore, politicians must be neutral to work with other racial politicians. Moreover, tolerance issues between races also important to manage government and political parties. If politicians are willing to be neutral to manage our political system, civilians still will satisfy our political party to lead our country. In addition, political culture in corruption also 
requires our current politicians to improve it. They can strictly propose various anti-corruption policies in governmental workplace and strictly obeying our governance.

Technological development could easily spread political issues for civilians to evaluate our political system. Obviously, political implementation is directly aware by civilians via current technological media such as internet and wireless technologies. Job vacancies in technological development also increased after proposed by governmental sectors. Thus, many information technology experts and engineers are working in Malaysia. To enhance our technological development, government and current political party must propose latest technologies from foreign country to replace outdated technologies in Malaysia. Moreover, freely utilizing technologies to provide political opinions are also an important policy to improve our political system. To avoid technological experts work in foreign countries, government has to increase remuneration for them comparing with other country's remuneration offered. We need them to develop our country in more stable situation by their experiences and knowledge. New invention and innovative ideologies could influence the status of local technological development due to global competitive issues always influence our civilians to critic our political system is not proceeded comparing with other well-performed in technological development countries. Thus, governmental staffs and politicians must update themselves from time to time to follow up global technological development. They also have to encourage civilians cater new ideas and innovative opinions to improve our current technological development. Marketing strategy is also an enhancement in technological utilization between civilians. They will replace current technologies by latest technologies in the societies to prove a proceeding country globally.

A safe and highly secured environment is considered as stabilized political system due to peaceful country always support by its civilians. To avoid civil war or civil chaos in a country, government must propose and implement various security systems in a country to protect civilians. Armed force, police force and security force should be enhanced by government and political party. Criminal issues also always interference local civilians. Thus, government should take the responsibility to concern on criminal activities too. In addition, government should not restrict media reporting criminal problems and political issues because civilians have their authority to know about it through democratic system. Any security deficiencies in societies must allow electronic media reports it without boundaries and allows civilians to voice up their problems and opinions. Therefore, government and current political party can propose solutions regarding to civilian's problems. Moreover, government can offer better conditional remuneration for civilians to join armed forces and police force that can enhance the quantity of security system to protect our country. Consequently, our political system can be stayed in stable situation while security environment is under highly consolidation for local civilians in Malaysia.

Democratic system requires civilians support it to retain its political system. In Malaysia, our political system must be supported by civilians in general election every five year. Thus, government has to provide various security solutions to protect civilians under peaceful country. The current political party always hopes political victory in general election continually to retain the political system. To retain the political system, government and political party have to cooperate with civilians. They have to observe security problems in societies from time to time and provide appropriates public protection based on civilian's requirements without racial-discrimination. Local civilians will still support current political system once their life had protected by existing governmental implementation and political party.

In Malaysia, we have many low-income civilians in the societies. In fact, government and current political party have to focus on social development seriously. Majority civilians unsatisfied their financial condition. Thus, government has to offer extra subsidies to help civilians. The extra subsidies can be given in educational scholarship, personal insurance, financial loan in low-interest, and other facilities to improve their lifestyle. Public facility establishment such as highway construction, train lane construction and primary schools establishment also needed to improve under social development. Government and current political party have to concern on that mentioned public facilities fairly for all races in Malaysia. National fund is the source to develop social industry. Thus, national politicians have to apply it wisely in our social development. They have to prevent corruption on that mentions funds too. If not, civilians will face public problems in the societies. In long term planning, political party and government are required to attract foreigner invest their funds in our social development by national strategies in diplomacy. It can reduce governmental burden and offering more and better social facilities under our social development. If current government concern on social development fairly and seriously for all civilians without racial-discrimination, local civilians will praise and satisfy our existing government and political party based on their kindness to take care about civilian's problems.

However our national governance has its authority to control social development regarding to local races distribution, our government and politicians also could treat our civilians fairly in social development. If they want civilians support our political system, government and current political party are required to provide public facilities regarding to all races requirement consistently but not only given prime priority for Malay race. On the other hands, government also has to obey our governance to restrict over freedom in social development 
to waste national funds. Although civilians always propose a lot of opinions and ideas in social development, current political party and government also needs to evaluate offered opinions and ideas from civilians either in proper condition under national governance or vice-versa.

\section{Conclusion}

In Malaysia, civilians described a stable political system for democratic country require several important factors such as organizational manpower development, economic development and its growth, governance, political culture, technology development, security environment and social development to stabilize political system for all Malaysians. A good relationship between the factor of economic development and its growth and the factor of political stability are decided by capable leaders and good strategies of inflation control factor. Moreover, a stable country requires both governance factor and political stability factor by intervention of control of corruption and capable leader factor to establish satisfied political system for all civilians. Our good correlation between both factor of technology development and factor of political stability also decided by new invention and innovation factor to satisfy national civilians. To protect civilians in a secured country, security environment factor should be concerned for the establishment of stabilised political system based on the interference of civilians support factor.

The strength of this study is to ensure and confirm our political system related to the mentioned factors based on civilian's perception. Thus, we could understand civilian's mindsets to let our government and current political party improve and enhance the mentioned factors to provide various contributions for all Malaysians. Government and current political party can utilize mentioned factors as a guideline to lead and satisfy our civilians as well as achieve stabilized political system permanently. In addition, government and current politicians also can concern their contributions in the mentioned factors to foster a stable country.

Some of the limitations encountered in the course of undertaking the research needs to be mentioned here. Firstly, the sensitive issues such as former Islamic religion in Malaysia does not include in this study due to national religions are consisting various races especially Chinese, Indian and Malay races. This issue may appear religion disagreement between Chinese, Indian and Malay races according to their personal religions and believes. Secondly, the survey will not do it in Eastern Malaysia, Sabah and Sarawak states due to the financial and time constraints. Thirdly, due the constraints of time, the structural interviewing questions were designed to be as simple as possible and could not accommodate more questions that might capture more information for this research. The simple interviewing questions already designed to reduce the complexity for low-educated respondents in Malaysia. Finally, the respondents were only being selected in two states (Perak and Selangor) to restraint data reliability for this research.

\section{Acknowledgements}

I would wish to express my appreciation and gratitude to those individuals who have provided me with the encouragement, support and understanding throughout the duration of my study including my parents, younger sister, and also my friends which I believe are crucial for the timely completion of my study.

I also would wish to say thank you for all respondents who provided useful data and information respectively. Fortunately, my final results could be performed on this research report. Without them, I could not complete my timely research.

Finally, I am deeply indebted to Dr. Shiva, the Dean at school of social science; University of Science Malaysia who was kind enough to permit me enrolling in University of Science Malaysia with his valuable assistance and support which enabled me proceed my research. His exemplary leadership is deeply appreciated.

\section{References}

[1] Abdullah, N. R. W. (2008). "Eradicating Corruption: The Malaysian Experience. Kuala Lumpur: Department of Administrative Studies and Politics." University of Malaya. JOAAG, Vol. 3, No. 1.

[2] Ali, A., Tan, S., Selvarathnam, S., Xu X. \& Saboor, A. (2008). "Political Stability and Balance of Payment: An Empirical Study in Asia. American Journal of Applied Sciences." 5 (9): 1149-1157.

[3] Alves, I. M. C. G. P. \& Silva, N. N. D. (2007). "Variance estimation methods in samples from household surveys." Rev Saude Publica: 41(6)

[4] Amucheazi, E. (1999). "Democratic Governance and Sustainable Peace and Stability in Nigeria. Nigeria." National Orientation Agency.

[5] Arrioda, L. R. (2008). "Patronage and Political Stability in Africa." Department of Political Science University of California.

[6] Asohan, A. (2009). "Law and Lawmakers". Starmag.

[7] Athukorala, P. C. \& Menon, J. (1997). "Export-led Industralisation, Employment and Equity: The Malaysian Case.” Australia National University \& Monash University Agenda, Volume 4, Number 1: 63-76.

[8] Bagce, H. E. (2002). "The Role of Political Institutions in Tackling Political Fragmentation and Polarization: Presidentialism versus Parliamentarism.” İktisadi ve İdari Bilimler Dergisi. Cilt 3. Say 1.

[9] Beadle, A. W. (2010). "Protection of Civilians in Theory - A Comparison of UN and Nato Approaches" Norwegian Defence Research Establishment (FFI).

[10] Bohn, F. (2003). "A Note on Corruption and Public Investment: The Political Instability Threshold.” Essex University. 
[11] Botosan, C.A. (1997). "Information Level and Cost of Equity Capital." The Accounting Review, Vol.72, No.3: 323-49.

[12] Bruderlein, C. (2001). "People’s Security as a New Measure of Global Stability.” RICR Juin IRRC, Vol. 83: 842.

[13] Burra, L. \& Ahmad, Md. I. (1991). "Impediments Facing New Zealand Exporters Developing Markets in Southeast Asia." Marketing Bulletin, Research Note 2: 60-65.

[14] Cai, F. \& Kam, W. C. (2000). "The Political Economy of Urban Protectionist Employment Policies in China." Working Paper Series No. 2

[15] Campos, N. \& Karanasos, M. (2007). "Growth, Volatility and Political Instability: Non-Linear Time-Series Evidence for Argentina, 1896-2000.” William Davidson Institute Working: 891.

[16] Caraher, K. (2000). "Issues in Incomes Provision for the Elderly in Malaysia." United Department of Sociology and Social Policy University of Durham.

[17] Chai, M. H. (2006). "The Racialisation of Election Issues and the Ideology of Malay Dominance in Malaysia." Institute of Malaysian and International Studies (IKMAS), Universiti Kebangsaan Malaysia.

[18] Chin, J. (1996). "The Sarawak Chinese Voters and Their Support for the Democratic Action Party (DAP)." Southeast Asian Studies, Vol. 34: 2

[19] Clark A. M. (2009). "Qualitative Research: What It Is and What It Can Contribute To Cardiology in the Young." Cambridge University Press, 19: 131-134.

[20] Dalton, R. J. \& Doh C. S. (2003). "Democratic Aspirations and Democratic Ideals: Citizen Orientations toward Democracy in East Asia." Center for the Study of Democracy University of California, Irvine and Department of Political Science University of Missouri.

[21] Davis, G. K. \& Kanago, B. E. (1998). "Inflation, Inflation Uncertainty, Political Stability, and Economic Growth." University Oxford. Ohio 45056.

[22] DeVaus, D.A. (1991). "Surveys in social research ( $3^{\text {rd }}$ edn)." UCL Press and Allen \& Unwin.

[23] Dobell, G. (2007). "China and Taiwan in the South Pacific: Diplomatic Chess versus Pacific Political Rugby." CSCSD Occasional: 1 .

[24] Dzunic, M. (2006). "Political Liberalization and Economic Reforms - Mutual Effects. Economics and Organization." Vol. 3, No 1: $95-104$

[25] Emmerson, D. K. (2008). "Asean's "Black Swans". National Endowment for Democracy and The Johns Hopkins University Press." Journal of Democracy Volume 19: 3.

[26] Evans, G. \& Laljee, M. (1997). "Political Talk and the Stability and Consistency or Political Orientation [Online]." Working Paper Number 61. [Accessed May 2009]. Available from World Wide Web: http://www.crest.ox.ac.uk

[27] Fabozzi, F. J., Focardi, S. M. \& Ma, C. K. (2005). "Implementable Quantitative Research.” The Journal of Alternative Investments.

[28] Fischer, J. (2009). "We Shift the Channel when Mahathir Appears: The Political Internet and Censorship in Malaysia." Akademika 75: 43-63.

[29] Foong, T. L., Koh, C., Looi, S., Chan, L. L., The, E. H., Loh, I. \& Singh, D. (2009). "Showdown Over Speaker's Seat.” Nation The Star.

[30] Fratzscher, M. \& Stracca, L. (2008). "The Political Economy under Monetary Union Has the Euro Made a Difference?.” Working Paper Series No 956

[31] Garland, R. (1991) “The Mid-Point on a Rating Scale: Is it Desirable?" Marketing Bulletin, Research Note 3.2: 66-70.

[32] Gershon W. S. (2008). "Qualitative Research, Intent and Expression." Kent State University, An International Journal of Complexity and Education, Volume 5, Number 1: $121-124$

[33] Goh, L. (2009). "High Court to Rule on Who Is The Rightful Perak MB on Monday." Nation The Star.

[34] Goldman, M. (2001). "The Twentieth Anniversary of the Democracy Wall Movement. Harvard Asia Quarterly." : 105.

[35] Greenhalgh T. \& Taylor R. (1997). "How to Read a Paper: Papers That Go Beyond Numbers (Qualitative Research) [Online]." BMJ. 315:740-743 [Accessed October 2009]. Available from World Wide Web: http://www.bmj.com/cgi/content/full/315/7110/740.

[36] Hindle, S. (2000). "The Growth of Social Stability in Restoration England." The European Legacy. Vol. 5, No. 4: 563-576.

[37] Ho, K. L. (1992). "Dynamics of Policy-making in Malaysia: The Formulation of the New Economic Policy and the National Development Policy.” National University of Singapore, Asian Journal of Public Administration Vol. 14 No. 2: 204-227.

[38] Huck, S.W. \& Cormier, W.H. (1996). "Reading Statistics and Research.” Harper Collins College Publisher.

[39] Ishak, M. M. (2002). "Managing Ethnicity and Constructing the 'Bangsa Malaysia' (A United Malaysian Nation)." Universiti Utara Malaysia, Malaysian Management Journal 6 (1 \&2): 99-1 15.

[40] Karamanlis, K. (2000). "Greece: The EU's Anchor of Stability in a Troubled Region.” The Washington Quarterly. 23:2: 7-11.

[41] Kato, S. (2002). "A Study of Research Method." Faculty of Business Administration, Bunkyo Gakuin University, 1196 Kamekubo, Oimachi, Iruma-Gun, Saitama 356-8533, Vol. 4, no. 1: 101 111

[42] Kervin, J.B. (1992). "Methods for Business Research.” HarperCollins.

[43] Khilani, S. (2002). "A proper basis for Indian stability." Financial Times U.K.

[44] Khoo, S. \& Kam, K. (2009). "Najib: BN may not contest polls." Sunday Star.

[45] Kreutz, J. (2006). "The Nexus of Democracy, Conflict and the Targeting of Civilians, 1989-2005" Department of Peace and Conflict Research, Uppsala University.

[46] Lawley, M. (2003). "Research Methods for Managers, Session 3." University of Sunshine Coast, Maroochydore.

[47] Lee, D.Y. \& Lee, J. (2008). "Democratic Consolidation beyond Political Crisis: An Experience of Korea." Journal of Contemporary Eastern Asia, Volume 7, No.2: 1-16.

[48] Leete, R. (2005). "Perak’s Human Development Progress and Challenges." United Nations Development Programme.

[49] Leete, R. (2004). "Pulau Pinang's Human Development Progress and Challenges." United Nations Development Programme.

[50] Leete, R. (2005). "Selangor's Human Development Progress and Challenges." United Nations Development Programme.

[51] Mageswari, M. (2009). "High Court Grants Leave to Nizar.” The Star.

[52] Mat, R. \& Taha, M. H. (2003). "Socio - Economic Characteristics of the Elderly in Malaysia." Department of Statistics.

[53] Milton, A. K. \& O’Neil, P. H. (2002). "The Conservative Peace: An Institutional Explanation of Post-Cold War Stability." International Politics 39 (September): 293-310.

[54] Molasso, W. R. (2006). "Theoretical Frameworks in Qualitative Research.” Northern Illinois University, Volume VII, No. 7.

[55] Monday, O. S. (2009). "Manpower Development in Nigeria: Conceptual and Methodological Perspectives." J Soc Sci, 18(2): $113-$ 117. 
[56] Morisi, P. (2006). "The Northern Ireland Peace Process and the Nationalist Political Parties: A Shift Toward Consociational Democracy [Online]." Peace Conflict \& Development, Issue 8. [Accessed May 2009]. Available from World Wide Web: www.peacestudiesjournal.org.uk.

[57] Muhib, F. B., Lin, L. S., Stueve, A., Miller, R. L., Ford, W. L., Johnson, W. D. \& Smith, P. J. (2001). “A Venue-Based Method for Sampling Hard to Reach Populations." Public Health Reports, Supplement 1, Volume 116.

[58] Mundell, R. (1999). "The Euro and the Stability of the International Monetary System." Columbia University.

[59] Myerson, R. B. (2006). "Federalism and Incentives for Success of Democracy." Department of Economics, University of Chicago, Quarterly Journal of Political Science, 1: 3-23.

[60] Neuman, W. L. (2006). "Social Research Methods Qualitative and Quantitative Approaches, Sixth Edition.” Pearson Education, Inc.: 220 .

[61] Norris, P. (2006). "Political Protest in Fragile States." IPSA 2006 - Political Action in Fragile States - Norris.

[62] Pendleton, G. W. (1995). "Effects of Sampling Strategy, Detection Probability, and Independence of Counts on the Use of Point Counts." USDA Forest Service Gen, Tech. Rep. PSW-GTR-159.

[63] Philips, L. (2006). "Assessing governance: How can political risk analysis help?"

[64] Polit D. F. \& Hungler B. P. (1995). "Nursing Research Principles and Methods." J.B. Lippincott Company.

[65] Regehr, E. (2006). "Briefing on the situation in Afghanistan." The Ploughshares Monitor Winter 2006. volume 27, no. 4.

[66] Robson, C. (1993). "Real World Research.” Blackwell.

[67] Roy, C. B. (2008). "Security seen as prerequisite for political stability - Sheikh Jaber." Arab Times.

[68] Sagoo, K. (2006). "Colonial Construction of Malay ness: The Influence of Population Size and Composition." International Graduate Student Conference Series.

[69] Samimi, A. J. \& Motameni, M. (2009). "Political Stability and of Inflation Targeting: New Empirical Evidence." University of Mazandaran, Australian Journal of Basic and Applied Sciences, 3(2): 1319-1322.

[70] Sato, M. (2005). "Education, Ethnicity and Economic: Higher Eduction Reforms in Malaysia 1957- 2003." NUCB, JLCC. 7. 1: 7388.

[71] Sedlak, A. J. \& Winglee, M. (2001). "Comparing the CIS and the NIS: Design Implications and Strategies.” Centre of Excellence for Child Welfare's Research Forum on the Canadian Incidence Study of Reported Child Abuse and Neglect (CIS).

[72] Sekaran (2003). "Research Methods for Business: A Skill Building Approach, (4 $4^{\text {th }}$ edn)." Wiley.

[73] Seligson, M. A. (2000). "Toward A Model of Democratic Stability: Political Culture in Central America." University of Pittsburgh.

[74] Siegel, P. Z. (2007). "Successful Scientific Writing: Step by Step.” Atlanta: MD, MPH -- CDC, GA.

[75] Solimano, A. (2003). "Governance crises and the Andean region: a political economy analysis." Economic Development Division.

[76] Tan J. (2009). "Rumours of Further Probe." The Star.

[77] Tauber, L. \& Sanchez, V. (2002). "Introducing the Normal Distribution in a Data Analysis Course: Specific Meaning Contributed by the Use of Computers." Universidad Nacional del Litoral Argentina \& Universidad de Sevilla Espana.

[78] Tey, N. P. (2002). "Social, Economic and Ethnic Fertility Differentials in Peninsular Malaysia." Faculty of Economics and Administration University of Malaya.

[79] The, E. H. (2009). "Khaled: UMMO Cannot Afford to be Race-centric." The Star.

[80] The, E. H. (2009). "April 22 Set for Mention of Karpal Singh's Sedition Case." The Star.

[81] The, E. H. \& Chooi C. (2009). "Ismail Needs a Job Now, BN Candidate Claims He Lost Because Opposition Played Dirty." The Star.

[82] Thompson, M. R. (2007). "The Dialectic of "Good Governance" and Democracy in Southeast Asia: Globalized Discourses and Local Responses.” Institute of Political Science, University of Erlangen-Nuremberg.

[83] Ufen, A. (2008). "The 2008 Elections in Malaysia Uncertainties of Electoral Authoritarianism." Taiwan Journal of Democracy, Volume 4, No.1: 155-169.

[84] Vinesh, D. \& Tan, A. (2009). "BN Leaders: Crisis Proves PKR and Pakatan are Incapable.” Sunday Star.

[85] Waguespack, D. M., Birnir, J. K. \& Schroeder, J. (2005). "Technological development and political stability: Patenting in Latin America and the Caribbean." Research Policy 34 (2005) 1570-1590.

[86] Wandschneider, K. (2005). "The Stability of the Inter-war Gold Exchange Standard Did Politics Matter?.” Economics Department Middlebury College Middlebury, VT. 05753.

[87] Wijayanto, Ir. (2007). "Corruption - A Cross Countries Analysis.” Universitas Paramadina.

[88] Woods, T. (2008). “Kenya's Stability Is an Important U.S. Priority." The Heritage Foundation No. 1852.

[89] Younis, M., Xu, X. L., Sharahili, Y. \& Selvarathinam, S. (2008). "Political Stability and Economic Growth in Asia." American Journal of Applied Sciences 5 (3): 203-208.

[90] Zablotsky, E. E. (1996). "Political Stability and Economic Growth.” A Two Way Relation.

[91] Zikmund, W.G. (2003). "Business Research Methods, ( $7^{\text {th }}$ edn)." Thomson Learning.

\section{APPENDIX - SAMPLE INTERVIEW QUESTIONS \\ SECTION A:}

Name:

Age:

Race:

State:
Gender:

Working Place:

Working Position:

Hometown:

\section{SECTION B:}

1. Do you think political stability in Malaysia require organizational manpower development? Why?

2. How to improve political system through organizational manpower development in Malaysia?

3 Do you think manpower development, and economic development and growth are related to stabilize political system in Malaysia? Why?

4. Do you think economic development and growth can influence status of political system in Malaysia? Why? 
5. How to improve existing economic development and growth to stabilize political system in Malaysia?

6. Do you think economic development and growth, and national governance are related to stabilize political system in Malaysia? Why?

7. Do you think national politicians, economists and control of inflation can improve current economic development and growth to stabilize political system? How?

8. Do you think political stability require national governance in Malaysia? Why?

9. How to stabilize political system through democratic system in Malaysia?

10. Do you think national politicians and control of corruption can improve current governance to stabilize political system? How?

11. Do you think political culture can influence status of political system in Malaysia? Why?

12. Do you think national governance and political culture are related to stabilize political system in Malaysia? Why?

13. How to stabilize political system by political culture in Malaysia?

14. Do you think political stability can be influenced by technology development? Why?

15. How to improve national technology development to stabilize political system?

16. Do you think new invention and innovation can enhance technology development to stabilize political system in Malaysia? How?

17. Do you think political stability is based on national security environment? Why?

18. How to consolidate security environment to stabilize political system in Malaysia?

19. Do you think our security environment require all civilians and citizens support it to maintain political stability? How?

20. Do you think political stability require social development in Malaysia? Why?

21. How to improve existing social development to stabilize political system in Malaysia?

22. Do you think national governance and social development are related to stabilize political system in Malaysia? Why? 